
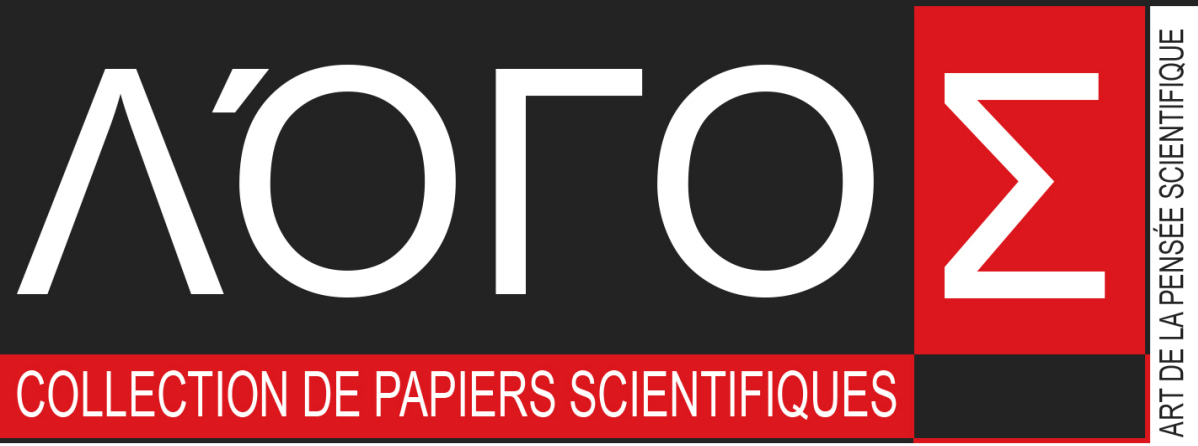

COLLECTION DE PAPIERS SCIENTIFIQUES

SUR LES MATÉRIAUX DE LACONFÉRENCE SCIENTIFIQUE ET PRATIQUE INTERNATIONALE

\title{
PROBLÈMES ET PERSPECTIVES D'INTRODUCTION DE LA RECHERCHE SCIENTIFIQUE INNOVANTE
} 29 NOVEMBRE 2019 •BRUXELLES, BELGIQUE Ш

\section{VOLUME 5}

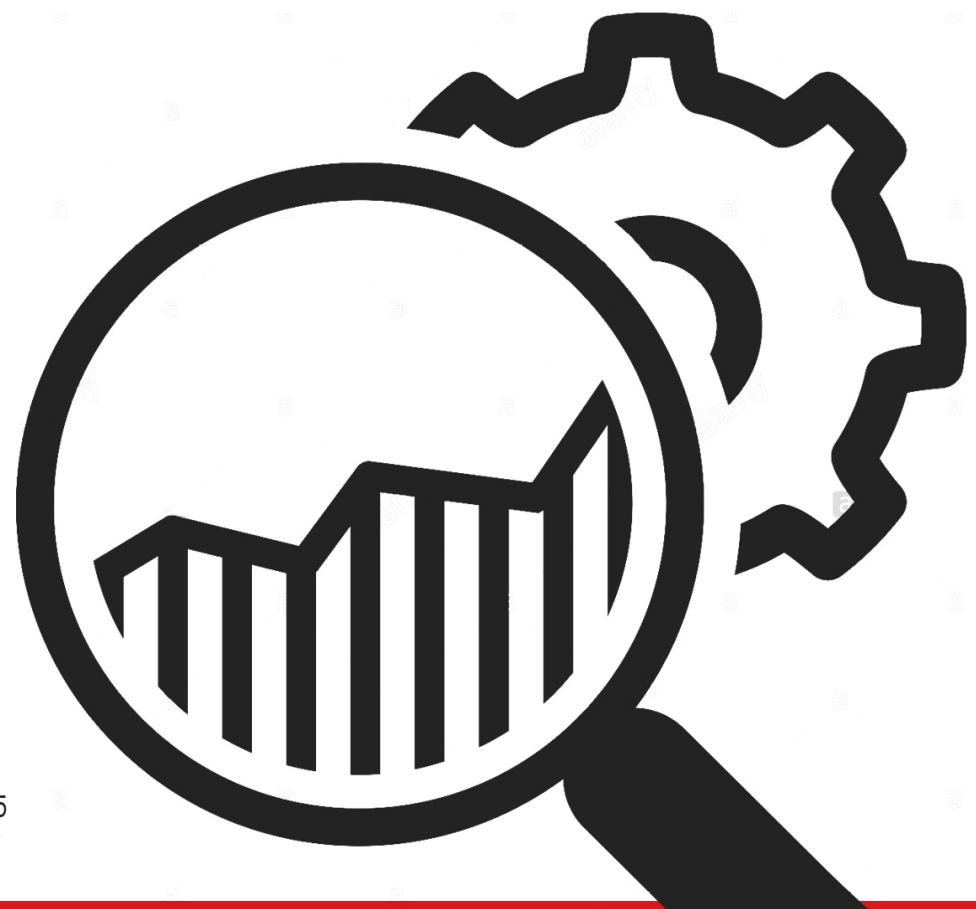



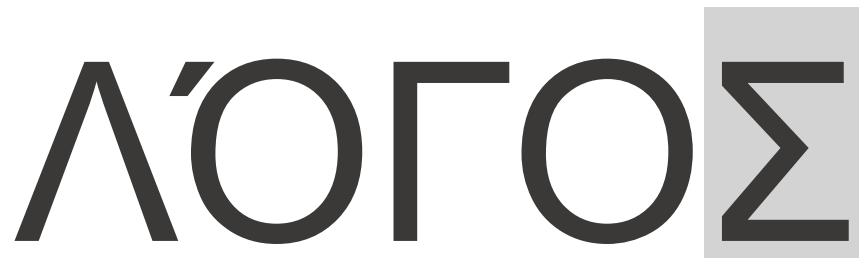

COLLECTION DE PAPIERS SCIENTIFIQUES

SUR LES MATÉRIAUX DE LA CONFÉRENCE SCIENTIFIQUE ET PRATIQUE INTERNATIONALE

«PROBLÈMES ET PERSPECTIVES D'INTRODUCTION DE LA RECHERCHE SCIENTIFIQUE INNOVANTE»

29 NOVEMBRE 2019

VOLUME 5

Bruxelles • Belgique 
P 93

Président du comité d'organisation: Holdenblat M.

Responsable de la mise en page: Kazmina $N$.

Responsable de la conception: Bondarenko I.

P 93 Problèmes et perspectives d'introduction de la recherche scientifique innovante: collection de papiers scientifiques

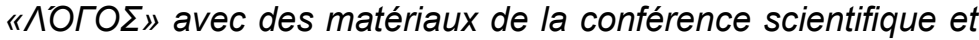
pratique internationale (Vol. 5), 29 novembre, 2019. Bruxelles, Belgique: Plateforme scientifique européenne.

ISBN 978-617-7171-89-7

DOI 10.36074/29.11.2019.v5

Les résumés et articles des participants à la conférence multidisciplinaire scientifique et pratique internationale «Problèmes et perspectives d'introduction de la recherche scientifique innovante», qui s'est tenue à Bruxelles le 29 novembre 2019, sont présentés.

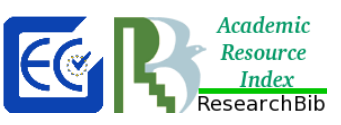

L'événement est inclus dans le catalogue des conférences scientifiques internationales, approuvé sur la plate-forme ResearchBib et certifié par Euro Science Certification Group norme scientifique SCC-2000.

Les documents de la conférence sont disponibles au public sous licence Creative Commons Attribution 4.0 International (CC BY 4.0).

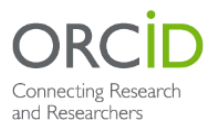

and Researchers

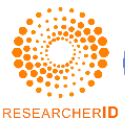

RESEARCHERID
La description bibliographique des documents de la conférence peut être téléchargée et indexée dans ORCID, Publons, Google Scholar, etc. 


\section{CONTENU}

\section{SECTION XI. SCIENCES PÉDAGOGIEQUES}

ІННОВАЦІЙНЕ СЕРЕДОВИЩЕ ПРОФЕСІЙНОЇ ДІЯЛЬНОСТІ ВЧИТЕЛЯ В УМОВАХ КОМПЕТЕНТІСНО ОРІЕНТОВАНОГО НАВЧАННЯ

Левченко Ф.Г. 7

ІННОВАЦІЙНІ ПІДХОДИ ДО ФОРМУВАННЯ ЗДОРОВ'ЯЗБЕРЕЖУВАЛЬНОÏ КОМПЕТЕНТНОСТІ В ЗАКЛАДАХ ВИЩОї ОСВІТИ

Бокшиц О.М. 9

ІНФОРМАЦІЙНА КОМПЕТЕНЦІЯ ТА ІНФОРМАЦІЙНА КОМПЕТЕНТНІСТЬ ЯК КОМПОНЕНТИ ПРОФЕСІЙНОЇ ПІДГОТОВКИ МАЙБУТНЬОГО ФАХІВЦЯ

Тирон В.О.

КОЛЕКТИВНІ ТВОРЧІ ЗАВДАННЯ У ПІДГОТОВЦІ МАЙБУТНІХ УЧИТЕЛІВ МУЗИЧНОГО МИСТЕЦТВА

Вергунова В.С.

КОМПЕТЕНТНІСНИЙ ПІДХІД ЯК ІННОВАЦІЯ У ПРОФЕСІЙНІЙ ПІДГОТОВЦІ МАГІСТРІВ З ПРОФЕСІЙНОЇ ОСВІТИ

Каменська І.С.

КОМПЛЕКС УМОВ ЗАСТОСУВАННЯ ТРЕНІНГУ ЯК ФОРМИ ОРГАНІЗАЦІЇ НАВЧАННЯ СТУДЕНТІВ ЗАКЛАДІВ ВИЩОЇ ОСВІТИ УКРАЇНИ

Трубавіна І.М., Каплун С.О.

КОУЧИНГ ЯК ІННОВАЦІЙНА ТЕХНОЛОГІЯ В СИСТЕМІ ОСВІТИ Багрій Г.В.

ЛУГАНСЬКА МАН ЯК ОСЕРЕДОК ТУРНІРНИХ РУХІВ ЛУГАНЩИНИ

Руда В.В.

ЛЭПБУК КАК СРЕДСТВО РАЗВИТИЯ ВНИМАНИЯ

Жилова Ю.П., Головко Ю.В.

МЕТОДИКА ВИКОРИСТАННЯ ПРОЕКТНОЇ ТЕХНОЛОГІЇ У ЗАКЛАДАХ ПРОФЕСІЙНОÏ ОСВІТИ

Кошкіна О.Ф.

ОБОГАЩЕНИЕ СЛОВАРНОГО ЗАПАСА ДЕТЕЙ МЛАДШЕГО ШКОЛЬНОГО ВОЗРАСТА С ЗАДЕРЖКОЙ ПСИХИЧЕСКОГО 
4 • Problèmes et perspectives d'introduction de la recherche scientifique innovante $\bullet$ Volume 5

РАЗВИТИЯ

Жилова Ю.П., Курмангалиева К.А. 32

ОГЛЯД СТРУКТУРНИХ ЕЛЕМЕНТІВ ОРГАНІЗАЦИЙНОЇ СИСТЕМИ ВИЩОÏ ОСВІТИ США

Гаврилюк Н.M.

ОСОБЕННОСТИ

ЭМПАТИЧЕСКИХ

СПОСОБНОСТЕЙ

n

ВЫРАЖЕННОСТЬ ГЕНЕРАЛИЗОВАННОГО ТРЕВОЖНОГО

РАССТРОЙСТВА У СТУДЕНТОВ МЕДИКОВ

Строчка О.Б.

ОСОБЛИВОСТІ ВПРОВАДЖЕННЯ МЕТОДОЛОГІЧНИХ ПІДХОДІВ ДО УПРАВЛІННЯ ЯКІСТЮ ОСВІТИ В ШКОЛІ

Ралько О.В.

ОСОБЛИВОСТІ МЕТОДОЛОГІЧНОГО АНАЛІЗУ ДОСЛІДЖЕНЬ ВПЛИВУ РІЗНИХ ФОРМ ТЕСТОВИХ ЗАВДАНЬ НА РЕЗУЛЬТАТИ ТЕСТУВАННЯ

Гривко А.В.

ОСОБЛИВОСТІ НАВЧАННЯ ХУДОЖНЬОМУ ТКАЦТВУ НА ТЕРЕНАХ ПІВНІЧНО-СХІДНОЇ УКРАЇНИ ХІХ - ПОЧАТКУ ХХ СТ.

Гулей О.В.

ОСОБЛИВОСТІ СИСТЕМИ ДОШКІЛЬНОЇ ОСВІТИ В БЕЛЬГІЇ

Прохорчук В.А.

ПОСАДА ЯК ЧИННИК ВІДМІННОСТЕЙ У ПРОФЕСІЙНОМУ МИСЛЕННІ ПЕДАГОГІВ

Лукіна Т.О.

ПРО ЛІНГВОДИДАКТИЧНІ ОСНОВИ РОБОТИ НАД КУЛЬТУРОЮ МОВЛЕНННЄВОГО СПІЛКУВАННЯ УЧНІВ

Сокаль М.А., Зобенкова (Просвіріна) С.О.

ПРО ПРОФЕСІЙНЕ СТАНОВЛЕННЯ МАЙБУТНЬОГО ВЧИТЕЛЯ ПОЧАТКОВИХ КЛАСІВ

Соколова Г.Б., Сокаль С.А.

ПРОФЕСІЙНА КОМПЕТЕНТНІСТЬ У ПІДГОТОВЦІ МАЙБУТНЬОГО ВЧИТЕЛЯ ТРУДОВОГО НАВЧАННЯ ТА ТЕХНОЛОГІЙ

Великдан Ю.В.

ПСИХОЛОГІЧНІ КОМПОНЕНТИ СТРУКТУРИ МЕТОДИЧНОЇ КОМПЕТЕНТНОСТІ ВИКЛАДАЧА УСНОГО ПЕРЕКЛАДУ

Пасічник Т.Д.

РЕЙТИНГОВА СИСТЕМА ОЦІНЮВАННЯ УСПІШНОСТІ СТУДЕНТІВ 3 
IHOЗЕМНОÏ МОВИ

Леонова О.М.

РОЛЬ ЕМОЦІЙНОГО ІНТЕЛЕКТУ У ПРОФЕСІЙНІЙ ДІЯЛЬНОСТІ ФІЗИЧНОГО ТЕРАПЕВТА

Волошко Л.Б.

РОЛЬ ПЕДАГОГА В ПРОЦЕССЕ ОСУЩЕСТВЛЕНИЯ SCRUM ТЕХНОЛОГИИ

Бобр А.Д., Мигдаль И.Ю.

СУЧАСНІ ІНФОРМАЦІЙНІ ТЕХНОЛОГІЇ У ПРОФЕСІЙНІЙ ПІДГОТОВЦІ МАЙБУТНІХ ПЕДАГОГІВ

Литвин А.Ф.

ТРЕНІНГ ДЛЯ СТАРШИХ ПІДЛІТКІВ-ВИХОВАНЦІВ ШКІЛ-ІНТЕРНАТІВ

Єрьоміна Л.є.

УДОСКОНАЛЕННЯ ТЕХНІКО-ТАКТИЧНОЇ ПІДГОТОВКИ БОРЦІВ ВІЛЬНОГО СТИЛЮ НА ЕТАПІ ПІДГОТОВКИ ДО ВИЩИХ ДОСЯГНЕНЬ Первачук O.I., Первачук P.В.

ФОРМУВАННЯ ПСИХОЛОГІЧНОЇ ГОТОВНОСТІ ДІЯЛЬНОСТІ ВИКЛАДАЧА ПРИ ВИКЛАДАННІ МАТЕМАТИЧНИХ ДИСЦИПЛІН

Полякова Є.В., Данильчук О.М.

\section{SECTION XII. SCIENCES PHILOLOGIQUES}

FOREIGN LANGUAGE IN THE INTERNATIONAL BUSINESS COMMUNICATION

Antonivska M.

FUNCTIONAL CHARACTERISTICS OF INTERNATIONAL ECONOMIC TERMINOLOGY

Pavlus T., Moshkovska L.

ТЕХНИКАЛЫК АУДАРМАНЫҢ
ТУЫНДАЙТЫН КЕЙБІР ҚИЫНДЫҚТАРЫ ТУРАЛЬ

Нұрмаханова М.К., Ахметова Э.Т.

ТЕХНИКАЛЫҚ ЖОҒАРЫ ОҚУ ОРНЫДАРЫНДА ҚОЛДАНЫЛАТЫН ТЕРМИНОЛОГИЯЛЫҚ СӨЗДІКТЕРДІ ҚҰРУ ПРИНЦИПТЕРІ

Нұрмаханова М.К., Ахметова Э.Т.

THE COMMUNICATIVE SITUATION IN THE BROADCAST POLITICAL INTERVIEW

Striuk T. 
6 • Problèmes et perspectives d'introduction de la recherche scientifique innovante $\bullet$ Volume 5

THE CONCEPT «IDIOSTYLE» AND ITS STRUCTURE IN CONTEMPORARY LINGUISTIC STUDIES

Kost' B.M.

THE SPECIFICS OF THE NOMINATIVE BEHAVIOR OF THE UKRAINIAN CITY DWELLERS IN THE ZOONYMY FIELD

Sablina S.

«БЕРЕМЕННОСТЬ» И «БЕСПЛОДИЕ» КАК ТРАДИЦИОННАЯ ОППОЗИЦИЯ В ФОЛЬКЛОРЕ ВОСТОЧНЫХ СЛАВЯН (НА ПРИМЕРЕ РУССКИХ ВОЛШЕБНЫХ СКАЗОК)

Антоненко Н.П.

ВІДТВОРЕННЯ МОДАЛЬНОСТІ У ПРОМОВАХ ПОЛІТИЧНИХ ЛІДЕРІВ ВЕЛИКОЇ БРИТАНІІ

Вдовиченко 0.О.

ДОСВІД ВИКЛАДАННЯ РОСІЙСЬКОЇ МОВИ В АРАБОМОВНІЙ АУДИТОРІї

Федоренко В.С.

ЕМОЦІЙНИЙ КОНЦЕПТ

Вінійчук А.C.

ІЗОМОРФНІ ТА АЛОМОРФНІ РИСИ СКЛАДНИХ РЕЧЕНЬ В АНГЛІЙСЬКІЙ Й УКРАЇНСЬКІЙ МОВАХ, ТА ОСОБЛИВОСТІ ПЕРЕКЛАДУ СКЛАДНИХ РЕЧЕНЬ

Ольшанецька О.В.

К ПОНЯТИЮ ЭКВИВАЛЕНТНОСТИ И АДЕКВАТНОСТИ КАК ИНДИКАТОРАХ КАЧЕСТВА ПЕРЕВОДА

Варлавина М.И.

КЛАСИФІКАЦІЙНІ ОЗНАКИ ЛІНГВОКУЛЬТУРНОГО КОНЦЕПТУ ЛЮДИНА

Гарбера І.В.

МОВА І МОВЛЕННЯ В УКРАЇНСЬКИХ ПРИСЛІВ'ЯХ І ПРИКАЗКАХ Зубець Н.О. 


\section{SECTION XI. SCIENCES PÉDAGOGIEQUES}

\section{ІННОВАЦІЙНЕ СЕРЕДОВИЩЕ ПРОФЕСІЙНОЇ ДІЯЛЬНОСТІ ВЧИТЕЛЯ В УМОВАХ КОМПЕТЕНТІСНО ОРІЕНТОВАНОГО НАВЧАННЯ}

ORCID ID: 0000-0003-4295-2934

Левченко Фессалоніка Григорівна

канд. пед. наук, доцент, старший науковий співробітник відділу профільного навчання

Інститут педагогіки НАПН України

УКРАÏHA

Соціально-економічні перетворення, що відбуваються в нашій країні за останнє десятиліття, створили умови для трансформуючих процесів у сфері освіти, серед них: створення нових типів шкіл, активне впровадження в практику різних педагогічних інновацій. Постійно змінююча ситуація в системі загальної освіти формує нові освітні потреби педагогів. Це призводить до закономірних змін в системі педагогічної освіти.

Активне запровадження компетентісного підходу передбачає застосування певних освітніх технологій в навчанні, рефлексію вчителів, оцінку власних досягнень в навчанні, самостійність застосування в практичній діяльності професійних умінь і навичок. Даний підхід сприяє розвитку у педагогів здібностей, професійної культури і педагогічного мислення.

Важливою складовою професіоналізму педагога $€$ підготовленість до самостійного виконання конкретних видів педагогічної діяльності: уміння вирішувати типові професійні задачі й оцінювати результати своєї роботи; здатність самостійно здобувати нові знання й уміння за фахом; уміння викласти навчальний матеріал; не лише володіти змістом предмета, але і використовувати педагогічні технології [1].

В умовах модернізації системи освіти, необхідний розвиток інноваційних процесів, орієнтація педагогів на освоєння та застосування інновацій у професійній діяльності, використання творчого підходу, який забезпечує особистий і професійний саморозвиток вчителя-предметника.

У Законі України «Про освіту» зазначено, що викладацька діяльність діяльність, яка спрямована на формування знань, інших компетентностей, світогляду, розвиток інтелектуальних і творчих здібностей, емоційно-вольових та/або фізичних якостей здобувачів освіти (лекція, семінар, тренінг, курси, майстер-клас, вебінар тощо), та яка проводиться педагогічним (науковопедагогічним) працівником [2].

Наявність сприятливого інноваційного середовища в педагогічному колективі сприяє: спрямованості формування особистості вчителя; формування фахівця, підготовленого до вирішення завдань цілеспрямованої соціалізації учнів; інтеграції не тільки науково-предметних, а й особистісно орієнтованих компонентів діяльності; забезпечення кожного педагога можливістю індивідуальної самореалізації, індивідуалізації навчальновиховного процесу; спрямованості на соціокультурні принципи. 
Згідно компетентісного підходу методичну майстерність вчителя може бути реалізовано ефективно тільки за умови широкого використання цього підходу, який сприяє формуванню важливих методичних знань і умінь, впливає на розвиток мислення, здатний змінити структуру професійного мислення, забезпечити готовність до самоосвіти і самопроектування.

Методична робота в закладі освіти - це цілісна, заснована на досягненнях науки і передового педагогічного досвіду і на конкретному аналізі навчальновиховного процесу система взаємопов'язаних дій та заходів, спрямованих на всебічне підвищення кваліфікації та професійної майстерності кожного педагога (включаючи і мотиви з управління професійною самоосвітою, самовихованням, самовдосконаленням педагогів), на розвиток і підвищення творчого потенціалу педагогічного колективу закладу освіти в цілому, а, в кінцевому рахунку, на вдосконалення навчально-виховного процесу, досягнення оптимального рівня освіти, виховання і розвитку конкретних вихованців [3].

Основним призначенням методичної роботи в інноваційному напрямку $є$ усунення недоліків і труднощів, які виникають в ході професійної діяльності, а також безпосередньо ефективна і продуктивна організація інноваційної діяльності, розробка нових підходів до її впровадження і контролю, пошук напрямків і способів взаємодії всіх членів управлінської ланки, а також розробка відповідного науково-методичного забезпечення. Під науковометодичним забезпеченням розуміємо сукупність форм і методів, що сприяють підвищенню рівня фрахової підготовки вчителя.

Найбільш поширеними формами науково-методичного забезпечення в межах інноваційної роботи є: формування методичних паспортів вчителя і освітнього закладу, що відбивають недоліки вчителя; робота корекційних та ініціативних творчих груп, методичних об'єднань, рад і кафедр; теоретичні семінари, практикуми, ділові ігри; робота школи молодого вчителя i педагогічного досвіду; твір тематичних альбомів, акумуляція базової інформації та розробок по темі школи; педагогічні ради та виробничі наради; доповіді та повідомлення; дискусії, дебати, полеміки з актуальних для освітнього закладу питань; консультації з науковими керівниками і залученими фахівцями; вивчення 3 досвідом інших освітніх установ, впровадження передового педагогічного досвіду; здійснення педагогічних консиліумів; досвідчена і експериментальна робота; виставки лабораторій вчителя; рецензування і критика; ділові, рольові та ситуативні ігри; побудова методичних рекомендацій; створення курсів і семінарів для вчителів; різні види індивідуально-групової роботи з окремими вчителями або педагогічними колективами; засідання методичних об'єднань вчителів по циклам предметів, ініціативних творчих груп, науково-методичної ради і кафедр і т.д.

Організація інноваційної діяльності вчительського колективу вимагає відповідних змін і координації управлінської діяльності адміністрації та наукових керівників школи. Ї̈̈ успішність залежить від оптимальності поєднання корекційної та інноваційної, предметної та позаурочної діяльності, різноманітності її форм і т.д.

Ця робота здійснюється в двох аспектах: корекційна робота, спрямована на виявлення та усунення недоліків і труднощів вчителів; навчання педагогів навичкам експериментально-дослідної роботи та розвиток необхідних для цього здібностей. 
У процесі створення науково-методичного забезпечення враховуються наступні критерії:

1) суб'єктність педагога в його професійній діяльності, що виражається в авторському підході до постановки цілей, вироблення змісту занять, розробці засобів створення ситуації розвитку особистості вихованця;

2) адаптованість до індивідуально-стильових особливостей вчителя;

3) співавторство вчителя і учня в розробці всіх компонентів педагогічного процесу - його цілей, засобів, очікуваних результатів, критеріїв їх оцінювання;

4) забезпечення єдності особистісно-смислового та когнітивного розвитку учнів.

Використання науково-методичного забезпечення сприяє: підвищенню рівня професійної діяльності вчителів, їх методичної майстерності, що підтверджується при проведенні навчальних занять, в процесі атестації; зростанню творчого рівня методичної роботи 3 елементами експериментальної діяльності; підвищенню рівня педагогічної майстерності вчителя для реалізації ідей компетентісно орієнтованого навчання; укладанню комплексу методичного забезпечення, що відповідає вимогам навчальних стандартів, сприяє формуванню компетентності учнів; розвитку профресійної компетентності, творчої індивідуальності вчителя, формування готовності до прийняття нового, розвиток сприйнятливості до педагогічних інновацій.

\section{Список використаних джерел:}

1. Жигірь, В.І. \& Чернега, О.А. (2012). Професіійна педагогіка: навчальний посібник. М.В. Вачевський (ред.). К.: Кондор.

2. Про освіту (Проект Закону України). Вилучено з https://zakon.rada.gov.ua/laws/show/214519.

3. Бабанский, Ю.К. (1985). Методы обучения в современной общеобразовательной школе : научное издание. М.: Просвещение.

\section{ІННОВАЦІЙНІ ПІДХОДИ ДО ФОРМУВАННЯ ЗДОРОВ'ЯЗБЕРЕЖУВАЛЬНОЇ КОМПЕТЕНТНОСТІ В ЗАКЛАДАХ ВИЩОЇ ОСВІТИ}

Бокшиц Олена Миколаївна

кандидат історичних наук, доцент ДВНЗ «Переяслав-Хмельницький державний педагогічний університет імені Григорія Сковороди»

УКРÄ̈HA

У сьогоденні здоров'я - це фундаментальна ланка у житті кожної людини, яка безпосередньо відображається на ії̈ буття, благополуччя, психічне та емоційне самопочуття.

Основна мета сучасних закладів вищої освіти (3ВО) України полягає у формуванні здорової як фрізично, так і духовно особистості. Тому кожен заклад 
вищої освіти сьогодні шукає свій шлях змін у просторі покращення якості освіти, виховання та навчання [1].

Саме у закладах вищої освіти відбувається підготовка майбутніх спеціалістів як пропагандистів і педагогів здорового способу життя та безпечної організації життєдіяльності на виробництві та в побуті.

У ЗВО викладається багато дисциплін, але інформаційний простір сьогодні майже безмежний (телебачення, Інтернет), тому викладач перестає бути єдиним джерелом знань. А метою сучасних вишів $є$ підготовка студентської молоді до складних реалій життя. Кожен студент має отримати під час навчання знання, що знадобляться йому в майбутньому житті. Здійснення означеної мети можливе у сучасному мобільному середовищі молоді за умови запровадження інноваційних підходів до фрормування здоров'язбережувальної компетентності.

Соціальні потреби щодо виховання здорового покоління роблять актуальною та посилюють здоров'язберігаючу складову у професійній підготовці майбутнього фахівця.

Розробка стандартів сучасного покоління актуалізувала проблему здоров'язбережувальної компетентності студентів вишів. У переліку ключових компетентностей, якими повинні володіти випускники закладів вищої освіти Н. Н. Завидівська із співавторами виділяють компетентність здоров'язбереження, як першорядної обставини збереження здоров'я [2].

Окремі сторони формування здоров'язберігаючої компетентності студентів, аналізують у своїх працях Д. Вороніна, В. Бобрицька, О. Митчик, О. Сапожник; формування культури здоров'я - Ю. Драгнєва, Г. Кривошея, Н. Башавець; фрормування здорового способу життя - О. Леонтьєва, В. Бабаліч, Л. Соколенко, Ю. Бойко, С. Лапаєнко, Л. Дурова, О. Вакуленко, Н. Завидівська, О. Марків; формування професійної компетентності педагогів присвячені праці Ю. Бойчук, О. Дубасенюк, Е. Добровольської, М. Левківського, Л. Лук'янової, А. Маркової тощо.

Багато сучасних і досвідчених вітчизняних дослідників виділяють, що формування здоров'язберігаючої компетентності у закладах вищої освіти, перш за все, повинно відповідати вимогам сучасності та допомогти майбутнім фахівцям у власному здоров'язбереженні, формуванні культури здоров'я та потреби у здоровому способі життя, упровадження здоров'язбережувальних інноваційних підходів та технологій і створення здоров'язберігаючого середовища у вищому навчальному закладі [7].

Інноваційні підходи реально стають запорукою компетентності та конкурентоспроможності студентів закладів вищої освіти. Так званий компетентнісний підхід розглядається багатьма системами освіти, як новий, такий, що впливає не тільки на саму структуру знань, а й на якість освіти в цілому.

Беззаперечно, виявлення інноваційних підходів до формування здоров'язбережувальної компетентності студентів закладів вищої освіти у процесі їхнього професійного спрямування має стати якісно новим процесом організації пізнавальної та професійної діяльності. Останній повинен будуватись на основі новітніх наукових знань про здоров'я, здоров'язбережувальних принципів та компетентностей, кваліфрікованого педагогічного забезпечення при активному використанні засобів навчання у ході науково-обґрунтованої організації викладання, яка базується на сучасних наукових підходах [4]. 
Модернізація змісту освіти стосується перш за все оновлення змісту розробки нових стандартів, оновлення навчальних програм тощо [3].

Це передбачає збільшення теоретичної та методичної підготовки задля формування ціннісного ставлення до професійного спрямування в аспекті формування здоров'язбережувальної компетентності. Відтак, зміст такої підготовки має інтегрувати сучасні соціальні та наукові досягнення. Останнє передбачає упровадження інновацій, новітньої та прогресивної методики задля підвищення ефективності процесу формування здоров'язбережувальної компетентності.

Із згаданих позицій розробка та впровадження інноваційних технологій у процесі здоров'язбережувальної компетентності студентів насамперед повинні бути орієнтовані на особистість, яка розвивається.

Обґрунтовуючи необхідність освоєння нововведень й упровадження їх у процес формування здоров'язбережувальної компетентності студентів до інноваційних зараховуємо ті нововведення, в яких втілено комплексне використання новітніх технологій й перебудови практики на шляху підвищення іï ефективності.

У сучасному сьогоденні зросла кількість досліджень, предметом яких стало використання інноваційних технологій, які базуються на досягненнях програмованого методу навчання і комп'ютеризації навчального процесу у професійному навчанні. Інтеграція нових інформаційних технологій у професійному навчанні студентів вищих закладів освіти передбачає методичне забезпечення занять сучасними технічними засобами.

Висновки. Проблема здоров'язбереження студентів закладів вищої освіти стала одним із чинників, що зумовили реформу вітчизняної освіти та зумовлюють необхідність інноваційного розвитку сучасного освітнього процесу вищих навчальних закладів, основним принципом якого $є$ принцип системності, що передбачає врахування розмірності всього комплексу змін освітнього процесу.

Головними складовими процесу формування здоров'язбережувальної компетентності фахівців $€$ навчальне середовище закладу вищої освіти, організація освітнього процесу, відбір і структурування змісту освіти, засоби організації навчально-пізнавальної діяльності студентів, орієнтовані на кінцевий результат.

\section{Список використаних джерел:}

1. Бокшиц, О.М. \& Каменська, І.С. (2016). Дидактичні умови використання нових інформаційних технологій у вивченні пожежної безпеки виробництв у ВНЗ. Журнал «Науковий огляд», (9), 77-90.

2. Завидівська, Н. Н. (2012). Фундаменталізація ффізкультурно-оздоровчої освіти: аспект здоров'язбережувального навчання студентів. Київ : УБС НБУ, ISBN 978-966-484- 139-6.

3. Загіка, О.О. (2012). Оновлення змісту професійної підготовки кваліфікованих робітників в сучасних умовах. Профресійно-технічна освіта, (4), 25-29.

4. Корягін, В. М. \& Блавт, О. 3. (2016). Педагогічні умови формування рухової компетенції у фізичному вихованні студентів спеціальних медичних груп. Теорія та методика фрізичного виховання, (3), 3-7. doi: http://dx.doi.org/10.17309/ tmfv.2016.3.1164.

5. Корягін, В. М., Блавт, О. 3., \& Череповська О.А. Інноваційні підходи у формуванні здоров'язбережувальної компетентності студентів спеціальних медичних груп у фізичному 
вихованні ЗВО. Вісник Чернігівського національного педагогічного університету, (152(2)).

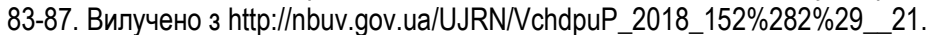

6. Носко, М. О., Гаркуша, С. В., \& Воєділова, О. М. (2014). Здоров'язбережувальні технології у фізичному вихованні. Київ: СПД Чалчинська Н.В.

7. Омельченко О. В. (2008) Особливості професійно-педагогічної діяльності вчителя початкових класів з організації здоров'язберігаючого навчально-виховного процесу: (автореф. дис. на здобуття наук. ступеня канд. пед. наук). Харків, Україна.

\title{
ІНФОРМАЦІЙНА КОМПЕТЕНЦІЯ ТА ІНФОРМАЦІЙНА КОМПЕТЕНТНІСТЬ ЯК КОМПОНЕНТИ ПРОФЕСІЙНОЇ ПІДГОТОВКИ МАЙБУТНЬОГО ФАХІВЦЯ
}

\author{
Тирон Володимир Октавянович \\ аспірант спеціальності «Освітні, педагогічні науки» \\ Харківський національний університет внутрішніх справ \\ УКРӒ̈HA
}

Сьогодні в умовах динамічного розвитку глобальних соціальних процесів у суспільстві все більше ускладнюються та актуалізуються завдання підвищення якості підготовки висококваліфікованих і конкурентоспроможних кадрів для всіх сфер життєдіяльності. Виходячи з цього, система освіти в Україні на межі XX і XXI століть перейшла на основи концепції компетентнісного підходу до освіти. Зауважимо, що цей перехід був зумовлений рядом причин, а саме:

- світова тенденція інтеграції, глобалізація світової економіки і, зокрема, неухильно наростаючі процеси гармонізації систем освіти, приєднання до Болонського процесу;

- прагнення освоїти досягнення розвинених країн;

- зміни освітньої парадигми.

У зв'язку з цим в педагогіку освіти міцно увійшли поняття «компетенція» та «компетентність». За даними зарубіжних експертів слова «компетентність» і «компетенція» існують з XXI століття відповідно до словника WEBSTEN, проте широке застосування вони отримали ще в XX столітті. Ці терміни активно використовуються в двох сфрерах: менеджменті та освіті. Вони передають наступні значення:

- здатність, необхідна для вирішення робочих завдань і для отримання необхідних результатів роботи, найчастіше визначається як компетентність;

- здатність, що відображає необхідні стандарти поведінки, визначається як компетенція.

Компетентнісний підхід в освіті пов'язаний з формуванням нової місії освіти, обумовленої, на думку вчених, змінами загальних світоглядних уявлень про людину та її сутність. Компетентнісний підхід, перш за все, виник в професійній освіті та був направлений на пошук відповіді: як вчити так, щоб на виході отримати компетентного професіонала. Освіта, заснована на компетенціях, сформувалася в $70-x$ роках XX століття в Америці в загальному 
контексті запропонованого Н. Хомським в 1965 році поняття «компетенція» стосовно до теорії мови, трансформаційної граматики. В розвитку даного підходу простежуються три етапи:

- I етап (1960-1970) - характеризується введенням у науковий апарат категорії «компетенція» і поняття «комунікативна компетентність» (Н. Хомський, Хаймс).

- II етап (1970-1990) - характеризується використанням категорії компетенція/компетентність в теорії та практиці менеджменту, в навчанні спілкуванню, появою розгорнутого тлумачення компетентності (Дж. Равен). В його роботі «Компетентність у сучасному суспільстві» (Лондон, 1984) дається тлумачення компетентності як явища, яке складається з великого числа компонентів, багато з яких відносно незалежні один від одного; деякі компоненти відносяться до когнітивної сфрері, інші - до емоційної; також вони можуть заміняти один одного. В цей період вітчизняні вчені не лише досліджують компетенції, виділяючи від 3 до 37 видів, а й будують навчання, маючи на увазі іiі фрормування як кінцевого результату цього процесу (Н. Кузьміна, Л. Петровська). Для різних видів діяльності дослідники виділяють різні види компетентності.

- III етап (90-ті роки по теперішній час) - компетентність характеризується як наукова категорія стосовно до освіти. Документи ЮНЕСКО ввели коло компетенцій, які повинні розглядатися як бажаний результат освіти. «Освіта прихований скарб», - вважає Жак Делор. Сформульовані ним 4 стовпи, на яких має ґрунтуватися освіта, як «навчитися пізнавати», «навчитися робити», «навчитися жити разом» і «навчитися жити», не втратили актуальності i сьогодні.

Провідний російський науковець Хуторськой А., досліджуючи дану наукову проблему, прийшов до наступного висновку: компетенція - це знання, вміння та досвід, іншими словами, це здатність вирішувати практичні завдання в різних сфрерах життя та діяльності на базі теоретичних знань і практичного досвіду; компетентність - володіння людиною відповідною компетенцією, що включає його особистісне ставлення до неї та предмету діяльності. «Компетенція - наперед задана вимога (норма) до освітньої підготовки учня», «компетентність - особистісна якість, яка вже склалася, і мінімальний досвід по відношенню до діяльності в заданій сфері» [1]. Загальновідомо, що українські вчені-педагоги перейшли до вивчення компетентнісного підходу в систематизованому вигляді, виходячи також з місії освіти, а саме: освіта протягом усього життя; освіта для миру та злагоди; освіта як фактор прогресу; освіта для життя і праці; освіта як умова та засіб формування планетарного мислення; освіта для всіх; освіта як відкрита система.

Під компетенціями вони розуміють такі якості особистості, які характеризують готовність, здатність інтегрувати отримані знання, вміння і навички в життєвий досвід для досягнення мети в певному контексті.

Оскільки ми розглядаємо інформаційну компетентність як системоутворюючий фактор, то визнали за необхідне звернутися до робіт В. Беспалька, Б. Гершунського, Н. Кузьміної та ін. Значиму цінність для нашої роботи становлять праці, присвячені теорії розвиваючого навчання та особистісно-орієнтованого підходу (Л. Виготський, П. Гальперін, М. Давидов, 
Д. Ельконін та ін.), а також дидактичним основам пізнавальної діяльності (В. Андрєєв, Ю. Бабанський, І. Єсіпов, І. Лернер, М. Скаткін, В. Тюріна та ін.).

Проблемам підвищення інформаційної культури фахівця, питанням оволодіння студентами інформаційними технологіями, ролі інформації в пізнавальній діяльності людини присвячено чимало досліджень. Інформацію як перетворену форму знання розглядало багато вчених: такі, як В. Афанасьєв, Ю. Арський, Р. Гиляревський, К. Казанцев, А. Урсул та ін. В контексті з освітньою діяльністю - Г. Воробйов, В. Коган, В. Сластенін, М. Тихонов, І. Усачова.

Інформаційна компетентність - виражена здатність особистості застосовувати свої знання та навички роботи з інформацією, представленою в різному вигляді, а також можливість ефективно використовувати ії в практичної діяльності. Продуктом діяльності, що відображає сутність та зміст інформаційної компетентності майбутніх фрахівців, є методика формування інформаційної компетентності, що представляє собою систему поглядів, теоретично обґрунтованих та об'єднаних спільною ідеєю, та що вказує спосіб створення педагогічних умов.

Ці умови дозволяють орієнтуватися в постійному багаторазовому прирості обсягу інформації, використовуваної для вирішення професійних задач; підготувати студентів до майбутньої професійної діяльності; ефективно взаємодіяти з соціально-інформаційним середовищем суспільства.

Рушійними силами формування інформаційної компетентності майбутнього фахівця є: опора у вивченні дисциплін професійного циклу на індивідуальний життєвий досвід студентів; прийняття студентом на особистісному рівні цінностей інформаційної діяльності людини; орієнтація та адаптація студентів в інформаційному потоці; проблемність наданої студентам інформації, гнучкість і адаптивність мислення при усвідомленні змісту інформації; робота з інформацією на основі нових інформаційних технологій; наукова організація праці при виборі та роботі 3 інформаційними першоджерелами; використання інформації для ефективного вирішення професійних завдань; соціально-професійна адаптація в швидко змінюваному інформаційному середовищі.

Компонентний склад інформаційної компетенції по-різному представлений в роботах дослідників з різних областей наукового знання. Зокрема, С. Трішина виділяє наступні компоненти [2]:

1) когнітивний - процес аналізу, переробки, отримання, передачі, прогнозування, надання, відбору та зберігання інформації. Іншими словами, це знання та коректне застосування інформації в професійній діяльності;

2) ціннісно-мотиваційний - створення мотиваційних цінностей, прояв інтересу до оволодіння та використання інформації, що сприяє розширенню знань, самовдосконаленню особистості, а згодом й передачі суми знань;

3) техніко-технологічний - робота 3 інформацією за допомогою інформаційних технологій. Комп'ютер стає головним засобом роботи 3 інформацією для навчальної мети;

4) комунікативний - використання мов (або інших знакових систем) для встановлення, підтримки спілкування та передачі інформації, оволодіння засобами спілкування (вербального, невербального); 
5) рефлексивний - самосвідомість і самооцінка особистості, вплив на думки інших. Цей компонент сприяє усвідомленню свого призначення в інформаційному суспільстві, відбувається саморегуляція професійної діяльності - всебічний аналіз результатів.

В. Котенко та С. Сурменко виділяють вже чотири компоненти [3]:

1) ціннісно-мотиваційний компонент - компонент, заснований на мотивуванні, наприклад, мотив отримання знань за допомогою комп'ютерних технологій;

2) когнітивний компонент - знання та вміння здійснювати різні операції 3 інформацією;

3) діяльнісний компонент - застосування нових інформаційних технологій для роботи з інформацією, наприклад, спілкування за допомогою синхронних i асинхронних засобів телекомунікації;

4) педагогічна рефлексія - самокритика та самовдосконалення в процесі професійної діяльності.

Дані класифрікації компонентного складу інформаційної компетенції носять суто теоретичний характер і не можуть бути використані на практиці в існуючому вигляді. Це відбувається тому, що не існує чіткої межі між вміннями, які складають різні компоненти. Навпаки, в реальному житті багато вмінь одночасно відносяться до декількох компонентів. Зокрема, вміння здійснювати пошук і відбір інтернет-ресурсів одночасно відноситься і до когнітивного компоненту, бо це вміння виробляти операції з інформацією, і до діяльнісного компоненту, що відображає здатність використовувати нові інфрормаційні технології для роботи з інформацією.

Удосконалення інформаційної компетенції пов'язано, по-перше, 3 розширенням джерел інформації, і по-друге, з розширенням умінь щодо їх використання.

В інформаційному суспільстві основою побудови життєвого плану $є$ володіння інформаційною компетенцією. Російський вчений О. Акулова вважає, що інформаційна компетенція студента - це узагальнене вміння працювати з інформацією, представленою в різних формах, вміння, що $є$ основою побудови життєвого плану. При цьому інформаційна компетенція характеризується вміннями здійснювати пошук, аналіз і використання інформації для побудови професійної кар'єри. Кар'єра розуміється не тільки як просування службовими сходами, а і як процес реалізації людиною на роботі своїх можливостей [4].

Як вже було зазначено вище, компетенції - це універсальні здібності, які проявляються в конкретній діяльності людини. Причому, як і будь-які здібності, вони не тільки проявляються, але й формуються в цій діяльності.

На думку дослідників, інформаційна компетенція сучасного фахівця складається з комплексу знань і вмінь, формування та розвиток яких має на увазі багаторівневу систему формування інформаційної компетенції, причому пріоритет надається діяльнісній складовій. Модель професійної компетенції фахівця передбачає визначення та опис ряду особистісних характеристик, особливостей мотивації, які пов'язані з професійною діяльністю. Інформаційна компетенція сьогодні - це один з основних елементів процесу професійного становлення випускника закладу фахової освіти. 
Висновки. Узагальнюючи вищевикладене, можна відзначити, що компетенція - це синтез знань і досвіду в конкретній галузі. Під компетенцією розуміють «сукупність знань, умінь і навичок, які формуються в процесі вивчення того чи іншого навчального предмета» (Т. Печеньова), «компетенція - це зміст освіти, який, будучи засвоєним учнями, формує компетентність» (А. Суригін). 3 огляду на зазначені визначення, нами пропонується наступне розуміння терміну «компетенція»: «Компетенція - це перелік знань, умінь, навичок, яким повинен оволодіти студент в результаті навчання, і який в кінцевому підсумку формує його компетентність в конкретній галузі діяльності». Виходячи з вищесказаного, компетентність - це здатність здійснювати діяльність з якістю, що забезпечує виконання професійних задач, досягнення цілей, отримання результатів. А компетенція - це здатність здійснювати діяльність 3 якістю, що відповідає стандартам і суспільним очікуванням.

Таким чином, і компетенція, і компетентність ґрунтуються на знаннях, уміннях, навичках, але компетентність включає і ставлення до результатів, суб'єкту, об'єкту, процесу діяльності та знаряддям праці. Коли говоримо про компетентнісний підхід, ми маємо на увазі, що очікуваними результатами навчання будуть компетенції та компетентність студентів. А в цілому, компетентнісний підхід - це підхід до визначення цілей, відбору змісту, організації освітнього процесу, вибору освітніх технологій та оцінці результатів. При підготовці майбутнього фахівця в закладі освіти важливу роль відіграє процес формування інформаційної компетентності, який в подальшому буде сприяти розвитку й вдосконаленню в нього інформаційнотехнологічної культури.

\section{Список використаних джерел:}

1. Хуторской, А. В. (2001). Современная дидактика. Спб: Питер.

2. Тришина, С. В. (2005). Информационная компетентность как педагогическая категория. Интернет-журнал «Эйдос». Вилучено 3 http://www.eidos.ruljournal/2005/0910-11.htm.

3. Котенко, В. В. \& Сурменко, С. Л. (2006). Информационно-компьютерная компетентность как компонент профессиональной подготовки будущего учителя информатики. Электронный научный журнал «Вестник Омского государственного педагогического университета». Вилучено $3 \mathrm{http}: / / \mathrm{ww}$.omsk.edu/article/vestnik-omgpu-114.pdf.

4. Акулова, О.В. (2003). Компетентностный подход в информмационном обществе: тенденции и проблемы. Известия Российского государственного педагогического университета имени А. И. Гериена, (3(6)), 17-26. Вилучено 3 https://cyberleninka.ru/article/n/kompetentnostnyy-podhod-v-informatsionnom-obschestve. 


\section{КОЛЕКТИВНІ ТВОРЧІ ЗАВДАННЯ У ПІДГОТОВЦІ МАЙБУТНІХ УЧИТЕЛІВ МУЗИЧНОГО МИСТЕЦТВА}

Вергунова Валерія Сергіївна

кандидат педагогічних наук, доцент кафедри мистецьких дисциплін Національний університет «Чернігівський колегіум» імені Т.Г.Шевченка

УКРӒ̈HA

У сфері підготовки майбутніх учителів музичного мистецтва важливим $€$ пошук нових форм і методів навчання, які були б спрямовані на вияв самостійності, креативності. Це зумовлюється основними тенденціями рефрормування шкільної освіти, увагою педагогічної спільноти до позакласної музично-виховної роботи, яка передбачає формування готовності студентів до постановки музично-виховних заходів різних видів у закладах середньої освіти. У зв'язку з цим постає необхідність використання навчально-творчих завдань, які сприятимуть розвитку організаційних навичок студентів, а також їхніх сценарно-режисерських умінь.

Проблема використання у навчальному процесі творчих завдань висвітлена у працях С. Рубінштейна, В. Моляко, В. Рибалки, С. Сисоєвої та інших. У тому числі й під час вивчення музично-педагогічних дисциплін (Д. Кабалевський, О. Ростовський, Г. Падалка, О. Щолокова та інші).

Навчально-творче завдання передбачає розвиток творчого потенціалу особистості, здатності до імпровізації. «Навчально-творче завдання - це така форма організації змісту навчального матеріалу, за допомогою якого педагог створює творчу ситуацію, прямо чи опосередковано визначає мету, умови, вимоги до навчальної творчої діяльності, в процесі якої суб'єкти навчання активно оволодівають знаннями та уміннями, розвивають власні творчі здібності», - вказувала С. Сисоєва [2]. Майбутній фахівець, який отримав досвід виконання творчих завдань, використовуватиме творчий підхід і в своїй подальшій професійній діяльності. Такий студент, як стверджував О. Ростовський: «..Усвідомлює значення й суть музично-освітньої і музичновиховної роботи, володіє досвідом творчого використання здобутків музичної педагогіки у своїй практичній діяльності» [1].

Колективні творчі завдання сприяють активізації творчої ініціативності студентів, їх самостійності. У контексті вивчення навчальної дисципліни «Методика постановки музично-виховних шкільних заходів» ці завдання передбачають сценарну розробку та презентацію музично-виховних заходів або їх фрагментів. Мета таких завдань полягає у можливості самовираження студентів, реалізації їхнього творчого потенціалу; формування мотивації до вивчення курсу, сприяють розвитку здатності працювати в команді.

Одним із видів колективних творчих завдань $€$ «театралізовано-ситуативні» завдання. Їх реалізація здійснюється у вигляді рольових ігор. Між студентами розподіляються ролі «режисерів», «сценаристів», «акторів», ведучих та учасників заходу тощо. Роль викладача при цьому зводиться до тактовної корекції та участі в обговоренні отриманих результатів. Студентам же надається якомога більший простір для франтазії, уяви, вираження індивідуальності свого мислення, творчості. 
Підготовка колективних творчих завдань потребує проходження низки етапів: пошукового (ознайомлення з темою), організаційного (розподіл ролей), підготовчого (репетиції); презентації; аналітичного (підбиття підсумків).

Отже, застосування колективних навчально-творчих завдань у процесі вивчення музичних дисциплін підвищують мотивацію оволодіння професією, дають впевненість у виконанні професійної музично-освітньої діяльності, передбачають оволодіння процесом підготовки заходів, виявляють навички роботи в команді.

\title{
Список використаних джерел:
}

1. Ростовський, О. Я. (2001). Методика викладання музики в початковій школі. Тернопіль: Богдан.

2. Сисоєва, С. О. (2006). Основи педагогічної творчості. Київ: Міленіум.

\section{КОМПЕТЕНТНІСНИЙ ПІДХІД ЯК ІННОВАЦІЯ У ПРОФЕСІЙНІЙ ПІДГОТОВЦІ МАГІСТРІВ 3 ПРОФЕСІЙНОЇ ОСВІТИ}

\author{
Каменська Ірина Степанівна \\ кандидат сільськогосподарських наук, доцент кафедри теорії \\ та методики професійної підготовки \\ Переяслав-Хмельницький державний педагогічний університет \\ імені Григорія Сковороди \\ УКРАÏHA
}

Вища школа - це основа для економічного розвитку та добробуту держави, певна річ, - показує правильний напрямок людству, сприяє розвитку логічного мислення, талантів, творчих та фрізичних здібностей студентів, формує національну свідомість, вчить використовувати сучасні інформаційні технології та ресурси у майбутній професійній діяльності та ін.

Українська педагогічна громадськість на сторінках педагогічної преси все частіше вживає тезу про необхідність запровадження компетентнісного підходу до професійної підготовки майбутнього фрахівця будь-якої галузі як «важливого шляху модернізації освітньої сфери». Тому й у керівних документах, що регламентують розвиток освітніх процесів, компетентнісний підхід визначається серед пріоритетних [3].

Стимулом для широкого використання компетентнісного підходу у світі стали вимоги бізнесу й підприємництва. Сучасні працедавці в більшості країн, як правило, не мають претензій до рівня технічних знань випускників вищих навчальних закладів, проте вони часто зауважують, що у випускників немає впевненості й досвіду в процесі інтеграції і застосуванні знань під час прийняття рішень. Саме тому допомогти навчитися знаходити правильні рішення в конкретних ситуаціях навчальних, життєвих, потім - профресійних $€$ сьогодні одним із провідних завдань освіти [3]. 
Відповідно до п. 5 статті 26 Закону України «Про вищу освіту» одним із основних завдань закладу вищої освіти є: забезпечення органічного поєднання в освітньому процесі освітньої, наукової та інноваційної діяльності. [5].

Крім того, стаття 65 Закон України «Про вищу освіту», акцентує увагу на тому, що основними завданнями наукової, науково-технічної та інноваційної діяльності закладів вищої освіти є:

1) одержання конкурентоспроможних наукових i науково-прикладних результатів;

2) застосування нових наукових, науково-технічних знань під час підготовки фахівців з вищою освітою;

3) формування сучасного наукового кадрового потенціалу, здатного забезпечити розробку та впровадження інноваційних наукових розробок [5].

Інновацію в освіті розглядають як реалізоване нововведення - у змісті, методах, прийомах і формах навчальної діяльності та виховання особистості (методиках, технологіях), у змісті і формах організації управління освітньою системою, а також в організаційній структурі закладів освіти, у засобах навчання та виховання і в підходах до соціальних послуг в освіті, що суттєво підвищує якість, ефективність та результативність навчально-виховного процесу [2].

Вимоги сучасного суспільства до кваліфрікації фрахівця диктують нові підходи до фрормування змісту освіти [6]. Вітчизняні науковці характеризують компетентнісний підхід як ключову інноваційну ідею сучасної освіти, яка матиме довготермінові наслідки не тільки для професійної освіти, а й для суспільства в цілому [4; 7]. Компетентнісний підхід за допомогою інноваційних методів навчання має забезпечити підняття рівня освіти за для того, щоб в кінцевому результаті магістранти могли успішно виконувати професійні обов'язки за обраною спеціальністю.

Одним зі шляхів оновлення змісту освіти й навчальних технологій, узгодження їх із сучасними потребами, інтеграції до світового освітнього простору $€$ орієнтація навчальних програм на компетентнісний підхід i створення ефективних механізмів його запровадження [1].

Традиційний підхід до підготовки фахівців у вищій школі, суть якого полягає у формуванні знань, умінь і навичок, прийшов у протиріччя до вимог європейського освітнього простору, в який інтегрується освітня система України.

При реалізації освітньої-професійної програми підготовки магістрів 3 професійної освіти заклад вищої освіти націлений на те, щоб майбутні фахівці знали основні концепції сталого розвитку суспільства, освіти і методології наукового пізнання; правові та етичні норми професійної діяльності; фундаментальні і прикладні аспекти наук про освіту; принципи управління персоналом та ресурсами; основні підходи до прийняття рішень й упровадження сучасних систем менеджменту у професійній діяльності відповідно до спеціалізації в умовах неповної/недостатньої інформації та суперечливих вимог. Та мали здатність уміти використовувати сучасні інфрормаційні технології та ресурси у професійній, інноваційній та/або науковій діяльності; формувати комунікаційну стратегію, здійснювати ділову комунікацію i доносити зрозуміло i недвозначно професійні знання, 
обґрунтовуючи й узагальнюючи інфрормацію для фахівців та широкого загалу; визнавати відповідальність за результати власної роботи в умовах суперечливих вимог; використовувати іноземну мову у професійній діяльності; діяти 3 дотриманням етичних норм, цінувати індивідуальне і культурне різноманіття, дотримуватися у професійній діяльності принципів толерантності, діалогу і співробітництва; обирати оптимальну стратегію колективної діяльності, міжособистісного спілкування та взаємодії для реалізації комплексних проектів у галузі (за спеціалізацією) з урахуванням наявних ресурсів та часових обмежень; застосовувати здобутки психологопедагогічної теорії та практики, навички консультування з питань освіти при проектуванні та реалізації навчальних/розвивальних проектів на засадах студентоцентрованого підходу; організовувати освітній процес (співпрацю в команді) студентів, керувати пізнавальною діяльністю, здійснювати педагогічний контроль і моніторинг результатів їх навчання; використовувати освітні технології і забезпечувати їх навчально-методичний супровід з метою створення сприятливого освітнього середовища; аналізувати і оцінювати стан господарської діяльності підприємств галузі відповідно до спеціалізації та ризики за умов неповної інформації та суперечливих вимог; визначати, критично оцінювати ключові тренди соціально-економічного розвитку галузі відповідно до спеціалізації та ризики їх упровадження або застосовування в інноваційній діяльності; обґрунтовувати підприємницькі ідеї і обирати відповідне проектній діяльності програмне забезпечення та інструменти (наприклад, дослідження ринку, статистичний аналіз, порівняльні показники); проводити експертну оцінку; удосконалювати з високим рівнем автономності набуту під час навчання кваліфікацію та проектувати напрями професійного самовизначення і розвитку команди; критично осмислювати теорії, принципи, методи і поняття з різних предметних галузей і застосовувати одержані знання, уміння і навички для вирішення практичних задач і проблем у галузі відповідно до спеціалізації; використовувати сучасні методи обробки і інтерпретації інформації при проведенні інноваційної діяльності; планувати виконання інноваційного завдання у виробничій сфері, формулювати висновки за його результатами та готувати результати розробок до оприлюднення [8].

Виходячи з вище сказаного приходимо до висновку, що національна модель підготовки фахівців спирається на досвід, набутий у європейській системі освіти. Компетентністний підхід як інновація у професійній підготовці магістрів з професійної освіти доповнює та покращує процес набуття знань.

\section{Список використаних джерел:}

1. Антонюк, Л. Л., Василькова, Н. В. \& Ільницький, Д. О. (2016) Компетентнісний підхід у вищій освіті: світовий досвід. Київ: КНЕУ.

2. Вакуленко, В. М. (2010). Види інновацій в освіті та їх класифікація. Вісник Національної академії Державної прикордонної служби України, (4).

3. Демченко, Д. І. (2015). Компетентнісний підхід до професійної підготовки представника юридичної професії. Вісник Дніпропетровського університету імені Альфреда Нобеля. Серія «Педагогіка і психологія». Педагогічні науки, ( 2 (10)), 131-135.

4. Заболотська, О.С. (2008). Компетентнісний підхід як освітня інновація: порівняльний аналіз. Вісник Житомирського державного університету ім. Івана Франка, (40), 63-68. 
5. Про вищу освіту (Закон України). (2019). № 1556-VII. Вилучено 3 https://zakon.rada.gov.ua/laws/main/1556-18

6. Каменська, І. С. (2016). Особливості вивчення дисципліни «Охорона праці в галузі» при професійній підготовці майбутніх викладачів вищих навчальних закладів. Науковий журнал «Науковий огляд». (9 (30)), 103-113.

7. Малик, Г. Д. (2009). Компетентнісний підхід у профресійній освіті: історія, теорія, практика. Івано-Франківськ: ТзОВ «ІМСТА».

8. Проект Стандарту вищої освіти України другий (магістерський) рівень, галузь знань 01 - Освіта/Педагогіка, спеціальність - 015 - Професійна освіта (за спеціалізаціями). (2018). Вилучено 3 https://mon.gov.ua/ua/osvita/visha-osvita/naukovo-metodichna-radaministerstva-osviti-i-nauki-ukrayini/proekti-standartiv-vishoyi-osviti.

DOI 10.36074/29.11.2019.v5.02

\section{КОМПЛЕКС УМОВ ЗАСТОСУВАННЯ ТРЕНІНГУ ЯК ФОРМИ ОРГАНІЗАЦІЇ НАВЧАННЯ СТУДЕНТІВ ЗАКЛАДІВ ВИЩОЇ ОСВІТИ УКРАЇНИ}

Трубавіна I.M.

д-р. пед. наук, професор, професор кафедри загальної педагогіки та педагогіки вищої школи Харківський національний педагогічний університет імені Г.Сковороди Каплун C.O. кандидат педагогічних наук, доцент, начальник кафедри технічного та тилового забезпечення фракультету логістики Національна академія Національної гвардії України

Актуальність пошуку нових методів і форм навчання студентів в умовах впровадження компетентнісного підходу ставить в кут уваги викладача тренінг як форму організації навчання, який традиційно використовувався лише в неформальній освіті і позакласній роботі. Причиною цього $\epsilon$ необхідність тривалого часу на налаштування учасників на навчання в інших умовах, інше розміщення учасників тренінгу, опора на тренінгу на їх власний досвід, у т.ч. пізнавальний, професійний, соціальний, який мають не всі студенти тощо. Разом з цим наш власний досвід проведення і організації тренінгів, теоретичний аналіз літератури 3 проблеми [1;2] дозволяють говорити про можливість використання тренінгу як форми організації навчання студентів за певних умов.

Перш за все визначимо поняття тренінгу як форми організації навчання - вона характеризується: практичною спрямованістю результатів навчання для вирішення певних професійних, пізнавальних чи соціальних проблем; цілями в напрямку розвитку компетентностей студентів (загальних i професійних); обмеженістю кількістю учасників до 20-22; вільним переміщенням і гнучким розташуванням учасників в просторі на занятті в залежності від завдань і цілей кожного етапу тренінгу; поєднанням різних методів навчання; опорою на власний пізнавальний та професійний, 
соціальний, життєвий досвід учасників; вільним висловлюванням думок і асоціацій учасників при наявності прийнятих усіма учасниками нормами поведінки на тренінгу; превалюванням групової та індивідуальної роботи учасників на занятті; збільшеною частиною практичної роботи учасників у порівнянні з засвоєнням нового (70\%-30\%); спеціальною роботою над мотиацією учасників як на початку, так і протягом усього тренінгу; психологічним комфортом і невимушенівстю на заняттях при наявній позиції ведучого; зміною ролі викладача на ведучого і фасилітатора і консультанта; високою відповідальністю студентів за свої рішення і їх обгрунтування; постійною зміною ролей учасників на занятті, їх місця в просторі; підвищеною самостійністю учасників на занятті.

Відзначимо, що тренінг має кілька етапів, які не можна подолати і пройти за 1 пару, їх не можна скорочувати, а традиційно він проводиться не менше 1 дня. Тому впровадження тренінгу в навчання студентів можливе лише за умови виділення як мінімум 3 пар поспіль 3 однієї навчальної дисципліни в розкладі в одній групі. Це -перша організаційна умова впровадження тренінгу в вищу освіту. Іншими організаційними умовами $€$ наявність аудиторій 3 пересувними столами і стільцями, проектором, екраном, ноутбуком, фліпчартом і бумагою для нього, канцтоварами для неї. Аудиторії в закладах вищої освіти сьогодні не обладнані таким чином і кошти на весь цей комплекс не виділяються. Тобто тренінг має ще й фрінансову умову впровадження. Технічною умовою впровадження тренінгу $є$ вміння викладачів і студентів користуватися обладнанням для тренінгу.

Педагогічними умовами впровадження тренінгу вважаємо: підготовку викладачів до написання, організації і проведення тренінгу як нової форми навчання у закладі вищої освіти, підготовку студентів до такого навчання; засвоєння ними правил поведінки на тренінгу; наявність суб'єкт-суб'єктних стосунків між викладачами і студентами для тренінгу, оскільки тренінг не може проводитися авторитарно і монологічно; зміна ролі викладача з лектора на ведучого, фасилітатора, консультанта, а студента -на зацікавленого суб'єкта навчання.

Дидактичними умовами впровадження тренінгу як форми навчання у заклади вищої освіти є: дотримання всіх етапів тренінгу і всіх етапів засвоєння на одному занятті при змінах в меншу сторону на час і інформацію на етапах сприйняття і усвідомлення та розуміння нового; вміння викладача підтримувати позитивну мотивацію у учасників до навчання протягом всього тренінгу, а не тільки для зацікавлення темою; вміння доводити сенс заняття і кожного його завдання для практичної діяльності майбутнього фахівця, організовувати його роботу самостійно і в мікрогрупах, в умовах постійних змін в розташуванні в просторі; організовувати по-іншому час тренінгого дня, ніж пари з перервами.

На основі викладеного можна зробити висновок, що тренінг може бути формою організації навчання в формальній освіті, закладах вищої освіти за виконання комплексу умов викладачем і студентами, адміністрацією закладу: організаційних, технічних, фрінансових, педагогічних і дидактичних.

\section{Список використаних джерел:}

1. Трубавіна І. М. \& Цибулько Л. Г. (2018). Формування загальних компетентностей майбутніх соціальних педагогів у світлі нових вимог до розробки освітніх програм. 
Проектування життєвої компетентності учнівської молоді/за ред. О. В. Кузьміної. ДВНЗ «ДДПУ»: Hameln: interGing.

2. Трубавіна, І. М. (2017). Особенности и методы обучения взрослых студентов в украинских университетах в системе последипломного педагогического образования, Актуальные проблемы профрессионального образования в Республике Беларусь и за рубежом, Материалы IV международной научно-практической конференции. Витебск: в 2-х ч. (1), Витебский филиал Международного университета «МИТСО», Беларусь.

DOI 10.36074/29.11.2019.v5.03

\section{КОУЧИНГ ЯК ІННОВАЦІЙНА ТЕХНОЛОГІЯ В СИСТЕМІ ОСВІТИ}

Багрій Ганна Вікторівна

заступник директора з навчально-виховної роботи Індустріальний коледж Державного вищого навчального закладу «Український державний хіміко-технологічний університет»

УКРАÏHA

Пріоритетним напрямом реформування сучасної освіти $€$ оновлення педагогічного процесу, внесення інновацій у традиційну систему, пошук оптимальних шляхів, що дадуть змогу виховати відповідальних громадян, які здатні до свідомого суспільного вибору та спрямування своєї діяльності на користь іншим людям і суспільству, збагачення на цій основі інтелектуального, економічного, творчого, культурного потенціалу Українського народу, підвищення освітнього рівня громадян задля забезпечення сталого розвитку України та її європейського вибору [1].

Сьогодні спостерігається перехід від суворо регламентованого життя всього суспільства та окремо взятої людини до вибудовування гнучких взаємовідносин у процесі міжособистісної комунікації. При цьому підвищення ефективності власної життєдіяльності можливе тільки за умови постійного розвитку та самовдосконалення особистості протягом усього життя, що проявляється у якісній і творчій реалізації власних професійних функцій, створенні умов для розвитку інших людей, що сприяють розв'язанню проблем будь-якого характеру.

Необхідною умовою цього процесу $\epsilon$ використання різноманітних інноваційних методів, вдосконалення як власної професійної діяльності, так і особистісного розвитку в цілому. Одним з таких методів є коучинг [2].

Сьогодні коучинг став предметом зацікавленості освітян, як інноваційна освітня технологія. Ця технологія ґрунтується на побудові взаємодії педагога та студента, де викладач зобов'язаний знаходити, освоювати і адаптувати нові знання. У свою чергу, студенти повинні приймати активну участь у педагогічному процесі, інакше у них не сформуються навички самоосвіти, яка в майбутньому надасть їм стійкої особтистісної конкурентної переваги.

Концепція коучингу максимально відповідає концептуальним основам сучасної освіти, тобто відповідає концепції особистісно-орієнтованого навчання, а коучингові навички органічно вбудовуються в профріль компетенцій сучасного викладача. 
Основоположником коучингового підходу вважається У. Тімоті Голві, викладач Гарвардського університету і тренер з тенісу, який зазначав, що коучинг - це методика розкриття потенціалу особистості для максимізації власної продуктивності та ефрективності. Коучинг більше допомагає особистості навчатися, ніж вчить. Це не тільки техніка, яка застосовується в певних обставинах, а ще і метод управління, метод взаємодії з людьми, а також спосіб мислення.

Коучинг - це мистецтво сприяти підвищенню результативності, навчанню і розвитку іншої людини. Він спирається не на знання, досвід, мудрість або передбачення коуча, а на здатність людини вчитися самому і діяти творчо (М. Дауні).

Згідно з цими визначеннями, коучинг можна розглядати і як науку, і як мистецтво (у створенні довірчих стосунків), і як процес, і як технологію, і як метод, і як новий тип мислення.

Застосування коучингу в педагогічному процесі передбачає:

- системний супровід студента, спрямований на ефективне досягнення важливих для нього цілей в конкретні терміни, в результаті чого у суб'єкта формується гнучкість і адаптивність до змін, здатність швидко і ефрективно реагувати в критичних ситуаціях;

- партнерське комунікативне співробітництво, що допомагає добиватися значних результатів у різних сферах життєдіяльності; - безперервний процес розвитку, вдосконалення, розкриття потенціалу особистості для досягнення максимального результату;

- систему взаємодії з коучем, із самим собою, з навколишнім світом;

- технологію, що дозволяє переміститися із зони проблеми в зону ефективного рішення; - засіб сприяння, допомоги особистості в пошуку ії власних рішень в складній для неї ситуації;

- модель взаємодії суб'єктів, завдяки якій коуч - викладач підвищує рівень мотивації і відповідальності, як у себе, так і у студентів;

- особливе підтримуюче ставлення до студента, згідно з яким він сам досягає своєї мети, сам вирішує проблеми, реалізуючи власні здібності і можливості;

- вид індивідуальної підтримки особистості, що ставить своїм завданням профресійне і особистісне зростання, підвищення персональної ефективності [3].

Застосування ідей коучингу на практиці означає поступовий перехід від традиційних аудиторних занять до тренінгової, індивідуальної, проектної, екстернатної і дистанційної форм роботи. Коучинговий підхід допоможе розвинути у студентів відповідальність, усвідомленість, самостійність в ухваленні рішень, підвищить їх мотивацію, особисту зацікавленість в процесі навчання та в практичній підготовці. Коучинг розвиває у студентів новий тип мислення, що грунтується на впевненості в собі і майбутньому, на позитиві і на бажанні взаємодіяти з оточенням, дотримуючись інтересів сторін.

\section{Список використаних джерел:}

1. Про освіту (Закон України). №38-39. (1994). Відомості Верховної Ради України.

2. Нежинська, О. О., Тименко В. М. (2017). Основи коучингу. Київ: ТОВ «ДІСА ПЛЮС».

3. Рудницьких, О.В. (2014). Коучінг як інтерактивна технологія в освіті. Вісник Дніпропетровського університету імені Альфреда Нобеля. Серія: Педагогіка і психологія, (2(8)), 173-176. 


\section{ЛУГАНСЬКА МАН ЯК ОСЕРЕДОК ТУРНІРНИХ РУХІВ ЛУГАНЩИНИ}

Руда Вікторія Вікторівна

кандидат історичних наук, доцент кафредри гуманітарних наук ДЗ «Луганський державний медичний університет»

УKPAÏHA

Турнірний рух - це ще один вид інтелектуальних змагань серед учнів старших класів, який стає все більш популярнішим в Україні. Мета турніру виявлення, розвиток і підтримка обдарованих дітей, підвищення інтересу школярів до поглибленого вивчення природничих дисциплін; залучення учнів середнього та старшого шкільного віку до науково-дослідницької діяльності в гуртках і секціях наукових відділень Малої академії наук України.

Значення турніру не можна не оцінити, оскільки він впливає не лише на розвиток здібностей сучасної молоді, її інтелектуальне становлення, світогляд, але й сприяє визначенню кола наукових інтересів, виявляє рівень знань, сприяє розвитку креативного та асоціативного мислення, вміння працювати командою. Саме останнє, передбачає спілкування з однолітками, колективне здобуття знань, пошук шляхів вирішення тих чи інших наукових проблем та завдань.

Турнір - це командна гра, в якій кожен учасник може продемонструвати свої знання, свої ораторські здібності, вибудовування власної тактики і стратегії виступів.

У процесі підготовки до цього виду змагань школярі навчаються самостійно планувати свою роботу, розподіляють напрямки діяльності, обмінюються думками, дискутують, навчаються приймати спільні рішення, консультуються 3 педагогами та науковцями - все це безумовно сприяє саморозвитку i самовдосконаленню.

Готуючись до турніру, учасники мають не лише здобути необхідну інформацію, але й опрацювати її, зробивши певні висновки. При цьому дуже важливо під час гри презентувати зроблене, тобто продемонструвати структуровану доповідь, в якій переконливо викласти всю необхідну інформацію та результати дослідження.

Як правило завдання турніру та рівень їх складності значно вищі ніж шкільна програма та не мають однозначного розв'язання. Це дає змогу учням можливість самостійно визначати методи та шляхи дослідження і розв'язання поставлених проблем.

З 2011 р. Луганщина також долучилась до турнірного руху України. I не дивлячись на зміни, які відбулися сьогодні, Луганська область, продовжує брати активну участь в ньому. На базі Луганської обласної малої академії наук учнівської молоді (яка з жовтня 2014 р. розташована у м. Рубіжне) проходять Обласні етапи Всеукраїнських турнірів за різними напрямами, а саме з історії, правознавства, журналістики, хімії, біології, математиків, економістів, фізиків, винахідників і раціоналізаторів. 
Переможці обласних етапів відстоюють честь та гідність Луганщини на Всеукраїнському рівні, за останні роки команди ЛОМАНУМ відвідали Ужгород (Всеукраїнський турнір юних правознавців 2016 р.), Дениші (Всеукраїнський турнір юних економістів 2016 р.), Чернігів (Всеукраїнський турнір юних істориків 2016 р.), Хмельницький (Всеукраїнський турнір юних хіміків 2016 р.), Полтава (Всеукраїнський турнір юних правознавців 2017 р.), Суми (Всеукраїнський турнір юних журналістів 2017 р.), Рівне (Всеукраїнський турнір юних біологів 2017 р.), Вінниця (Всеукраїнський турнір юних істориків 2017 р., Всеукраїнський турнір юних правознавців 2018 р.), Кам'янець-Подільський (Всеукраїнський турнір юних істориків 2019 р.) [1].

Проте, на жаль, не всі міста та райони сучасної Луганської області беруть участь в Обласних турнірах. Як показує практика, це учні навчальних закладів переважно з найближчих міст та районів до м. Рубіжне, осторонь залишаються Білокуракінський, Біловодський, Макрівський, Міловський, Новоайдарський, Новопсковський, Попаснянський, Станічно-Луганскьий, Старобільський Троїцький райони. Таку пасивність мабуть можна пояснити тим, що не всі педагогічні працівники чітко розуміють навіщо потрібні турніри і чим вони відрізняються від олімпіад чи конкурсу-захисту робіт учнів-членів МАН, турніри позбавлені багатьох «матеріальних» стимулів. Крім того, підготовка команди потребує від вчителя певного часу, оскільки, як ми вже зазначали, існує особливість завдань, які пропонуються учасникам.

Таким чином, турнірний рух Луганщини знаходиться у стані розвитку та набуває свої традиції. Наявність проблем свідчить про розвиток та вдосконалення цього руху, головним завданням якого залишається створення умов для навчання і розвитку талановитої молоді, надання мотивації до креативної діяльності та дослідницької роботи.

\section{Список використаних джерел:}

1. Офіційний сайт Луганської обласної малої академії наук учнівської молоді. Вилучено з: http://lugansk.man.gov.ua/news/Regionalni_novini_LOMANUM/Vseukrainskij_turnir_junih_prav oznavtsiv/;http://lugansk.man.gov.ua/news/Regionalni_novini_LOMANUM/JUni_ekonomisti_na_ ZHitomirschini//http://lugansk.man.gov.ua/news/Regionalni_novini_LOMANUM/VSEUKRAINSKI J_TURNIR_JUNIh_ISTORIKIV/;http://lugansk.man.gov.ua/news/Regionalni_novini_LOMANUM/ Finalnij_etap_turniru_junih_himikiv/;http://lugansk.man.gov.ua/news/Regionalni_novini_LOMAN UM/XV_Vseukrainskij_turnir_junih_pravoznavtsiv/;http://lugansk.man.gov.ua/news/Regionalni_n ovini_LOMANUM/Finalnij_etap_turniru_junih_biologiv/;http://lugansk.man.gov.ua/news/Regional ni_novini_LOMANUM/XV_Vseukrainskij_turnir_junih_zhurnalistiv/;http://lugansk.man.gov.ua/ne ws/Regionalni_novini_LOMANUM/JUni_istoriki_na_Podilli/;http://lugansk.man.gov.ua/news/Regi onalni_novini_LOMANUM/Vseukrainskij_turnir_junih_pravoznavtsiv_2018/,http://lugansk.man. gov.ua/news/Regionalni_novini_LOMANUM/page/8/ 


\title{
ЛЭПБУК КАК СРЕДСТВО РАЗВИТИЯ ВНИМАНИЯ
}

\begin{abstract}
Жилова Юлия Павловна
магистр педагогики и психологии, старший преподаватель кафедры

психологии и дефектологии Костанайский государственный педагогический университет им. У. Султангазина
\end{abstract}

Головко Юлия Васильевна

студентка 4 курса специальности «Дефектология» Костанайский государственный педагогический университет им. У. Султангазина

РЕСПУБЛИКА КАЗАХСТАН

В государственной программе «Цифровой Казахстан» приоритетным направлением является развитие человеческого капитала, которое направлено на использование цифровых технологий как для усвоения новых, так и для совершенствования уже полученных знаний у учащихся [1].

Современное образование направлено не только на накопление знаний учащихся, но и для воспитания личностей, которые будут легко ориентироваться в проблемах и справляться с трудными ситуациями, принимая разумные решения. Очень значимую роль в накоплении знаний играет внимание. Оно является необходимым условием успешности процесса обучения, так как регулирует работу всех психических фрункций, задействованных в процессе обучения. Это и восприятие, и память, и мышление, и воображение. Без волевого подключения внимания к этим процессам они могут либо вовсе не работать на усвоение материала, либо быть задействованы в очень низкой степени, недостаточной для достижения результата обучения. Именно поэтому создание эффрективных ресурсов для активизации внимания учащихся является актуальной темой образовательного процесса. За вниманием всегда стоят интересы и потребности, установки и направленность личности. Они вызывают изменение отношения к объекту. А изменение отношения к объекту выражается во внимании - в изменении образа этого объекта, в его данности сознания: он становится более ясным и отчетливым, как бы более выпуклым [2]. По словам М. И. Данилова [3], интерес учеников является предпосылкой их активности. Исходя из этого важно «установить способы провоцирования их интереса, создать позитивную мотивацию для сознательной и эфффективной работы, основанной на стремлении к пониманию, познанию жизни» [4]. Для этого необходимо определить подходы, методы, средства и формы обучения, чтобы учащиеся были не только независимы, но и активно участвовали в процессе обучения. Поэтому, чтобы активизировать внимание и впоследствии развить у учеников дары и личные способности чрезвычайно важно находить новые методы и подходы в обучении.

С быстрым развитием нашей среды через технологии и информационные системы, сегодняшние отношения и интересы учащихся требуют, чтобы методы обучения, основанные на интерактивных ресурсах, использовались чаще. Организация учебного процесса должна включать проектирование интерактивных образовательных ресурсов, их правильное планирование и 
целенаправленное применение в процессе обучения и воспитания учащихся, с тем, чтобы можно было достичь установленных в новых нормативных положениях образовательных приоритетов. В настоящее время, необходимо, чтобы в школах были внедрены новые интерактивные средства, неизвестные до недавнего времени. Одним из таких средств является Lapbook (лэпбук) интерактивный образовательный инструмент, способствующий активизации внимания у учащихся в конкретной области обучения.

Термин "Лэпбук" был впервые введен мамой и писателем из Вирджинии, США Тэмми Дюби, которая использовала в домашнем обучении своих детей данное средство для систематизации информации. Она назвала ее так, именно потому, что весь лэпбук умещается и на коленях ребенка.

Существуют разные определения лэпбука. По словам Анны Чабуткиной, это учебный инструмент [5], по мнению Виктории Бурдовицыной, это метод [6], Ольга Азарова классифицировала его как специфическую форму организации изучаемого материала [7], поскольку в нем полностью представлена необходимая информация, гарантирующая изучение данного предмета. Она состоит из различных кармашков, конвертов, мини-книжек, окошек, подвижных деталей, вставок, которые можно доставать, складывать и перекладывать по своему желанию. Это могут быть картины, фотографии, короткие тексты, загадки, стихи, игры, рассказы, головоломки и т. д. В ней компонуется материал, определенной тематики.

Исторически «записная книжка» является преемником «складных», сложенных или вырезанных буклетов Дины Зайк различной формы. Разница между складками Зайк и Лэпбуком заключается в их организации. Записная книжка представляет собой набор из множества складок со всей информацией в ней. Лэпбук - это интерактивное пособие в виде папки формата A4, сложенной определенным способом, на прочной картонной (или иной) основе, в которую вставлены различные вкладки (миникнижки - простые и фигурные, кармашки, окошки и т.д.), подвижные детали, иллюстрации на заданную тему.

Лэпбуки приходят на помощь тогда, когда нужно эффективно и быстро освоить новый материал, также его можно использовать для обобщения и систематизации знаний, умений и навыков учащихся по определенному предмету и для закрепления ранее полученных знаний в занимательно игровой форме. Эти тематические папки имеют четкую структуру и яркое оформление. Внимание и интерес ребенка, как к самой книге, так и к информации в ней вызваны очень занимательно и увлекательно. [8]:

Для создания лэпбука необходимо знать об основных этапах его развития

1. Определение темы. Лэпбук может охватывать одну общую тему или ее часть.

2. Содержание лэпбука. Организация всех рубрик и подзаголовков.

3. Модель лэпбука. Расположение решаемых элементов.

4. Марка лэпбука. Разработка интерактивной папки путем составления ее элементов и их размещения в соответствии с макетом на предыдущем этапе.

Преимущества использования лэпбука:

1. Пробуждает у детей интерес к познавательной деятельности.

2. Развивает творческие способности, креативность, речь и мышление. 
3. Способствует разнообразию учебного процесса.

4. Использование лэпбука помогает ребенку эфрфективнее запомнить материал и лучше его понять.

5. Это идеальный способ, чтобы повторить пройденный материал. Благодаря тому, что лэпбук яркий и красочный, с разнообразными конвертиками и вложениями, ребенок с большим удовольствием будет повторять пройденные темы.

6. Лэпбук приходит на помощь при дифреренцированном обучении. Когда дети работают в группах, можно выбирать задания по уровню сложности в соответствии с их индивидуальными особенностями.

7. При работе с лэпбуком ребенок учится самостоятельно распределяться, полученной информацией.

Мы полагаем, что использование лэпбука на уроках повысит внимание учащихся. Лэпбук можно использовать как в непосредственно образовательной деятельности, так и для индивидуальной работы с ребенком. Использование лэпбука в процессе обучения формирует познавательную активность учащихся и способствует развитию творческого мышления, что повысит уровень внимания. Его применение помогает решить большинство учебных задач, так как задания и информация в лэпбуке подразумевают интеграцию образовательных областей, а также затрагивают разные виды деятельности ребенка.

\section{Список использованных источников:}

1. Государственная программа «Цифровой Казахстан». Изъято из https://docs.google.com/viewerng/viewer?url=http://www.akorda.kz/upload /media/files/a0632264810b20c36ed2a4f55d095ad2.docx

2. Рубинштейн С.Л. (2005). Основы общей психологии. Спб; Питер.

3. Данилов М. (1961). Развитие самостоятельных учеников и творчества в образовании. Советская педагогика, (98), с. 33.

4. Пейчева Ю.Г. (2008). Когнитивная активность и самостоятельность учащихся на уроках «Домашняя экономика» в I - IV классе. Начальное образование, (2), с. 58 - 67.

5. Изъято из $\mathrm{http}: / / w w w . t a v i k a . r u / 2014 / 09 / \mathrm{JVIK}-$ lapbook.

6. Изъято из http: //homeedukrblogspot.bg/2013/01/lapbook.html

7. Изъято из http://nsportal.Ru/школа^iologiya/library/2015/ 02/03/lapbook279Использование-науроках-биологии

8. Изъято из http://slunchicata.weeblv.com/105110721087107310911082lapbook.html 


\title{
МЕТОДИКА ВИКОРИСТАННЯ ПРОЕКТНОЇ ТЕХНОЛОГІЇ У ЗАКЛАДАХ ПРОФЕСІЙНОЇ ОСВІТИ
}

\author{
Кошкіна Олена Флоріанівна \\ старший викладач вищої категорії \\ Нікопольський технікум Національної металургійної академії України \\ УКРАЇ̈А
}

Сьогодні проектна технологія все більше привертають увагу викладачів закладів професійної освіти, оскільки дають можливість ефективно забезпечити розвиток фахових компетентностей студентів. Наявність реального кінцевого результату роботи над проектом позитивно відрізняє цю технологію від інших.

На сьогодні почала формуватися практика сучасної проектної освіти, але залишається ще багато не розв'язаних проблем:

- немає єдиного загально прийнятого погляду на навчальний проект;

- не відпрацьовано організацію виконання проектів учнями в умовах класно-урочної системи;

-низька теоретична і практична підготовка вчителів до проектної діяльності.

У цьому контексті, важливого значення, набуває проблема створення відповідної методичного забезпечення проектного навчання. Власний досвід багаторічної роботи дозволив мені розробити та запропонувати методику використання проектної технології у закладах професійної освіти [1].

Методика складається з п'яти етапів.

На першому (діагностичному) етапі здійснюється підготовка викладачів циклової комісії до системного запровадження проектної технології. Далі викладачі, які опанували методику розроблення проектів, виконують діагностику проблем, суперечностей, що мають бути вирішені впродовж проектної діяльності. Суттєвого значення має вибір виду проекту (інформаційний, науково-творчий, дослідницький, практично-орієнтований, тощо).

На другому (організаційному) етапі викладачі обґрунтовують дидактичну мету та визначають освітні завдання проектної технології. Визначають критерії оцінювання результатів проектної діяльності студентів. Мотивують студентів.

Оцінювання спрямовується на визначення рівнів оволодіння студентами навичками мислення, професійними вміннями, способами комунікації, методами вирішення проблем. Хоча кожен проект має власні цілі та особливості, треба заздалегідь визначити загальні параметри, за якими оцінюються його результати: глибину розкриття теми; логічність викладання; науковість, ефективність та доцільність технічних пропозицій; якість оформлення матеріалів; яскравість презентації, логіку і культуру мовлення під час захисту проекту тощо.

Під час фрормування первинної мотивації застосовують такі методи мотивації та стимулювання навчання, як комунікативна атака, визначення проблемної ситуації та переконання. На стадії підтримки та підсилення 
мотивації використовують методи долання перешкод і делегування. На цьому етапі слід також враховувати специфрічні особливості навчальних груп, серед яких: різнорідність складу за навчальною мотивацією, навчальними можливостями, наявність студентів з відхиленнями у поведінці, одностатевий склад груп.

Гарантією ефективності впливу на студентів $є$ вмотивованість викладача

На третьому (проектному) етапі викладачі разом із студентами обговорюють конкретні проблеми, що підлягають розв'язанню під час проектної діяльності та формулюють проектні завдання, виконують проекти

На четвертому (презентаційному) етапі студенти презентують результати власної проектної діяльності. Відбувається захист та оцінювання проектів.

Під час оцінювання проектної діяльності студентів необхідно застосовувати експертне (зовнішне) оцінювання. Експертами можуть бути інші викладачі, одногрупники, студенти старших курсів, представники базових підприємств, зрештою - спеціальна комісія з компетентних осіб, яка створена спеціально для оцінювання проекту. На незалежну експертну оцінку проектні роботи студентів можуть бути представлені у ході проведення предметних тижнів, науково-практичних конференцій, конкурсів тощо [2].

Завершальний (рефрлексивний) етап проектної технології. Аналіз студентами власної роботи у ході виконання проекту передбачає самопізнання, об'єктивне оцінювання власних сил і можливостей, об'єктивне і критичне ставлення до себе та результатів власної діяльності. Студенти можуть оцінювати і зміни мотивації у навчанні: зростання професійних цінностей, інтересів, потреб. Самооцінка учнів також дозволяє викладачу отримати корисну інформацію про них, зокрема, про труднощі на різних етапах виконання проекту та забезпечити педагогічно доцільну допомогу у подоланні таких труднощів (створення системи із зворотнім зв'язком). На цьому етапі доцільно також проаналізувати ефективність використання проектної технології, проаналізувати проблеми, що виникали під час проектного навчання, та позитивні особливості реалізації і впливу проектної діяльності на навчальний процес закладу професійної освіти.

Отже, використання проектної технології дозволяє студентам закладів вищої освіти синтезувати знання із професійних та природничо-наукових дисциплін, застосовувати їх на практиці. Такий підхід дає можливість викладачам підвищити ефективність професійної спрямованості підготовки майбутніх молодших спеціалістів технічного профрілю.

\section{Список використаних джерел:}

1. Корбутяк, В.І. (2010). Методологія системного підходу та наукових досліджень. Рівне: НУВГП.

2. Крушельницька, О.В. (2009). Методологія та організація наукових досліджень. Київ.: Кондор.

3. Палеха, Ю.І. (2013). Основи науково-дослідної роботи. Київ: Ліра-К. 


\section{ОБОГАЩЕНИЕ СЛОВАРНОГО ЗАПАСА ДЕТЕЙ МЛАДШЕГО ШКОЛЬНОГО ВОЗРАСТА С ЗАДЕРЖКОЙ ПСИХИЧЕСКОГО РАЗВИТИЯ}

Жилова Юлия Павловна

магистр педагогики и психологии

старший преподаватель кафедры психологии и дефектологии Костанайский государственный педагогический университет им. У. Султангазина

Курмангалиева Карина Аллабергеновна

студентка 4 курса специальности Дефектология Костанайский государственный педагогический университет им. У. Султангазина

РЕСПУБЛИКА КАЗАХСТАН

Согласно Закону РК «О социальной и медико-педагогической коррекционной поддержке детей с ограниченными возможностями»: «Дети имеют доступность и равные права на раннюю поддержку, и образование, независимо от степени ограничения способностей, возраста, социального статуса» [1].

Одна из наиболее распространенных в современном обществе причин неуспеваемости учеников - задержка психического развития, которая является среди различных фрорм психических нарушений одной из наиболее часто встречающихся. Свыше половины легких отклонений в умственном развитии квалифицируются педагогами и психологами как «задержка психического развития» [2].

На данный момент проблема изучения детей с задержкой психического развития не только набирает обороты, но и становится глобальной.

Наиболее общеупотребительное и полное определение было дано В.В. Лебединским (1985), который под задержкой психического развития понимает замедление темпа фрормирования познавательной и эмоциональной сфер с их временной фиксацией на более ранних возрастных этапах [3].

Садвакасова А.Е отмечала, что деятельность детей с задержкой психического развития (далее: дети ЗПР) характеризуется общей неорганизованностью и недостаточной целенаправленностью [4].

В связи с разнообразными подходами к изучению проблемы ЗПР, было выделено несколько классификаций (Г.Е. Сухарева, М.С. Певзнер, В.В. Ковалев). Но наибольшие возможности для медико-психологопедагогической практики представляет этиопатогенетическая классификация К.С. Лебединской $(1975,1982)$ :

1) ЗПР конституционального происхождения;

2) ЗПР соматогенного происхождения;

3) ЗПР психогенного происхождения;

4) ЗПР церебрально-органического генеза.

Речь детей младшего школьного возраста с задержкой психического развития имеет ряд особенностей. Изучение речи детей с ЗПР обнаруживает 
недостаточное развитие их словарного запаса (особенно активного) по уровню речевого развития. Эти дети соответствуют нормально развитым детям более младшего возраста.

У детей с задержкой психического развития отмечается ограниченный словарный запас. Характерным признаком для этой группы детей является более значительное, чем в норме, расхождение в объеме пассивного и активного словаря. Дети понимают значение многих слов; объем их пассивного словаря может быть близок к норме. Однако употребление слов в экспрессивной речи, актуализация словаря вызывают большие затруднения.

Дети с ЗПР, несмотря на зачастую слабо выраженную или отличающуюся значительным полиморфизмом клиническую симптоматику, имеют ряд достаточно характерных признаков - незрелость сложных форм поведения, недостаточность целенаправленной деятельности на фоне быстрой истощаемости, утомляемости, нарушенной работоспособности, являющихся причиной стойкой неуспеваемости в массовой школе [5]. Также, одним из ведущих признаков нарушения в познавательной сфере ребенка с данной аномалией является бедность коммуникации и скудный словарный запас.

Развитие словарного запаса ребенка является одним из наиболее существенных фракторов подготовки к самостоятельной жизни. Дети, которые не овладели достаточным лексически обогащенным словарным запасом, испытывают чаще всего трудности в обучении, не находя нужным по смыслу слов для выражения своих собственных мыслей.

Проблема изучения словарного запаса детей является одной наиболее распространенных в современной психолого-педагогической науке. С точки зрения психологии, словарный запас - общий объем слов, которые знает и понимает человек (пассивный словарный запас), использует в письменной и устной речи (активный словарный запас). В психологии обычно подразумевается, что словарный запас касается объема слов родного языка, носителем которого является конкретный человек [6].

Словарный запас является одним из элементов речевого развития детей. Усвоение словаря решает задачу формирования понятий, развития содержательной стороны мышления, накопления и уточнения представлений, словарь можно определить как пассивный и активный. Под пассивным словарём понимают возможность восприятия самих слов, под активным употребление этих слов в речи. Уровень развития словаря определяется количественными и качественными показателями [7].

А. М. Бородич [8] утверждал что, активный словарь - это слова, которые говорящий не только понимает, но и употребляет. В активный словарь ребенка входит общеупотребительная лексика, но в отдельных случаях - ряд специфических слов, повседневное употребление которых объясняется условиями жизни ребенка.

Пассивный словарь - слова, которые говорящий понимает, но сам не употребляет. Пассивный словарь значительно больше активного, сюда относятся слова, о значении которых человек может догадаться по контексту. Если у взрослого в пассивный словарь чаще всего входят специальные термины, диалектизмы, архаизмы, то у ребенка - часть слов общеупотребительной лексики, более сложных по содержанию [9]. 
По мнению Н. С. Жукова под активным словарем ученый понимает часть словарного состава языка, которая не только понятна определенному человеку, но и свободно употребляется им в его обыденной жизни, пассивный словарь выступает как часть словарного состава языка, понятная конкретному человеку. [10].

Развивать словарный запас, необходимо у всех детей, не учитывая их психические и физиологические особенности.

Исходя, из вышесказанного можно сделать выводы:

1. Объем словарного запаса детей с задержкой психического развития значительно меньше, чем у детей с нормой.

2. Младшие школьники с ЗПР имеют трудности в употреблении многих частей речи, в отличии от детей в норме словарный запас которых включает в себя все части речи.

3. У детей с ЗПР возникают трудности актуализации словаря. Таким образом, словарный запас детей младшего школьного возраста с ЗПР отражает трудности осознания явлений, своеобразие познавательной деятельности этих детей, ограниченность их представлений об окружающем мире.

Мы полагаем, что одним из эффективных средств, способствующих развитию словарного запаса младших школьников с задержкой психического развития является театрализованная деятельность.

Театрализованная деятельность является источником глубоких переживаний и открытий ребенка, развития чувств, приобщает его к духовным ценностям, полагается что это - конкретный, зримый результат.

С. Н. Томчикова считала что, театрализованная деятельность школьников - это специфический вид художественно-творческой деятельности, в процессе которой ее участники осваивают доступные средства сценического искусства, и согласно выбранной роли участвуют в подготовке и разыгрывании разного вида театральных представлений [2].

Исследователи, такие как П. П. Блонский, П. Ф. Каптерев, Р. И. Жуковская, Н. С. Карпинская, Л. С. Фурмина, Е. А. Медведева, изучавшие театрализованную деятельность нормально развивающихся школьников и детей с задержкой психического развития, указывают на важность ее как для развития познавательной деятельности и эмоциональной сферы, так и для развития словарного запаса. Включение подобной формы учебной деятельности подразумевает то, что будет происходить расширение представлений детей о театрализованной деятельности, разработку различных театральных постановок и их роль в этой постановке.

\section{Список используемых источников:}

1. http://adilet.zan.kz/rus/docs/Z020000343

2. Томчикова, С. Н. (2002). Подготовка студентов к творческому развитию школьников в театрализованной деятельности. Магнитогорск: МаГУ.

3. Лебединская К. С. (ред.) (1982). Актуальные проблемы диагностики задержки психического развития. Москва. 
4. Садвакасова, Н.А., Иванов, А.С., Селина, Е.В. \& Шовкань, И.П. (2016). Направления коррекционной работы с младшими школьниками с задержкой психического развития. Международный журнал прикладных и фундаментальных исследований, (№ 4-2), 464-468.

5. Певзнер, М.С. (1980). Клиническая характеристика детей с задержкой психического развития. Дефектология, (3).

6. Абрамова, Г.С. (1997). Возрастная психология. Москва: Издательский центр «Академия».

7. Гудкова, Т.В. (2007). Основы специальной педагогики и психологии. Новосибирск: НГПУ.

8. Бородич, А. М. (1999). Ступеньки развития. Ранняя диагностика и коррекция задержки психического развития. М.:Просвещение.

9. Волосовец, Т. В. (2002). Основы логопедии. М.: Академия.

10. Жукова, Н. С., Мастюкова Е. М. \& Филичёва Т. Б.(1998). Логопедия преодоление общего недоразвития речи у дошкольников. Екатеринбург: Издательство «Союз».

\section{ОГЛЯД СТРУКТУРНИХ ЕЛЕМЕНТІВ ОРГАНІЗАЦІЙНОЇ СИСТЕМИ ВИЩОЇ ОСВІТИ США}

Гаврилюк Наталія Михайлівна

канд. пед. наук, доцент, доцент кафедри іноземної фрілології та перекладу Вінницький торговельно-економічний інститут КНТЕУ УКРӒ̈HA

Мета статті полягає в огляді особливостей організації системи вищої освіти США. Навчальний процес в університетах США характеризується індивідуальним підходом до студентів. На основі опрацьованої літератури можемо стверджувати, що існують певні аспекти індивідуального підходу до студентів в університетах США:

1) свобода у часовому просторі, виділеному на вивчення дисциплін;

2) неможливість перейти до наступної теми, якщо попередня не була достатньо засвоєна;

3) складання навчальної програми самим студентом під методичним керівництвом викладача;

4) зосередження на лекції як не на основному методу отримання інформації, а на як ознайомлені з інформацією, яка б спонукала студентів до самостійного ії̈ подальшого пошуку;

5) надання важливості письмово виконаним роботам;

6) декількаразова перевірка знань студентів інспекторами-методистами тощо [1]. Як бачимо, університети США характеризуються індивідуальним підходом до студентів, які навчаються або лише мають на меті обрати напрямок для здобуття освіти.

Як констатує один із освітніх сайтів, обираючи університет, американський студент дивиться на статус вищого навчального закладу, аналізує, чи існує відповідність міжнародним вимогам для навчання, чи існують сертифрікати акредитації, який рівень кваліфрікації викладачів, що саме пропонують соціальні програми, тощо. У США співвідношення державних та приватних вищих закладів виглядає десь як 1:1, при цьому державні - безкоштовні. 
Серед лідерів-університетів знаходимо Йель, Каліфорнійський Технологічний інститут, Стенфорд, Гарвард, Прінстонський Університет та Масачусетський Технологічний Інститут та Чикагський Університет, Колумбійський Університет, Університет Пенсільванії, Університет Дюка, Мічіганський Університет, Університет Карнегі-Меллон та інші. [2].

Особливості вибору вищого навчального закладу в США ще полягають у тому, що лише після вступу студент визначається з вибором спеціальності, причому спочатку йому пропонують широкий спектр навчальних курсів за різними інтересами, пізніше - поглиблене вивчення обраної спеціальності. Важливо обрати так званий "тајог" - головний предмет для вивчення. $€$ можливість обрання подвійної спеціалізації, наприклад, математику та економіку.

США характеризується відсутністю суворих вимог щодо процесу вступу до університету, хоча необхідно пред'явити документи про завершення середньої школи, перелік вивчених предметів із отриманими балами, результати співбесіди, де, як правило, перевагу надають характеристикам учителів та додатковим відомостям про студента стосовно його позанавчальної діяльності (гуртки, секції, олімпіади, участь у фестивалях, спортивних заходах тощо).

Вступ до вузів США залежить від престижності останніх. Одні університети проводять конкурсні іспити, тестування, співбесіди тощо, а інші приймають студентів за умов наявності в них документів про завершення середньої школи (йдеться про дворічні коледжі).

Університети зазвичай доводять до відома абітурієнтів, з яких предметів тести пропонуються і скільки балів необхідно набрати для того, щоб вступити до університету.

Якого-небудь планового прийому та випуску фрахівців у масштабі країни в США не існує. Так як навчається різновікова категорія студентів, то термін навчання є також необмежений. Існує можливість зупинити навчання i поновити його навіть через декілька років [3].

Студенти обирають вуз залежно від своїх фрінансових можливостей та розумового потенціалу. Навчання в державному університеті обходиться студенту приблизно в середньому 6 тисяч доларів на рік (вартість навчання невисока в порівнянні з американськими стандартами). Групи в державному закладі $€$ досить великими, наприклад, лекції відвідують 200 студентів, практичні заняття - близько 50 студентів. Самостійна позааудиторна робота студентів складає більшу половину навчання в державному університеті. Державна вища освіта США характеризується самостійністю студента у власній навчальній діяльності.

Вартість навчання у приватних закладах вищої освіти в США $є$ досить високою (15 тис. доларів на рік.). Кількість студентів у групах невелика - 10-15 студентів. Як правило, високий рівень професорсько-викладацького складу, достатнє матеріально-технічне забезпечення, відведення великого часу аудиторній роботі з досвідченими викладачами $є$ основними особливостями недержавних вищих навчальних закладів. Недержавна вища освіта США характеризується спільною відповідальністю навчального закладу за навчання студента [1].

Розглядаючи систему вищої освіти США, слід звернути увагу на мінімальні вимоги для вступу до вищих навчальних закладів, рекомендовану успішність та фрінансові питання, пов'язані з вартістю навчання.

Переддипломна (Undergraduate) освіта. 
1. Дворічні коледжі (Community та Junior). Для вступу необхідно мати диплом про середню освіту (High School Diploma). Можливо отримати асоційований ступінь з гуманітарних наук (Associate of Arts - AA) або асоційований ступінь з природничих наук (Associate of Science - AS).

2. Чотирирічні університети та коледжі. Для вступу необхідно мати диплом про середню освіту. Присвоюється ступінь бакалавра (Bachelor's Degree). Вартість за навчання складає від 3000 до 29000 доларів за навчальний рік. Чотирирічні університети та коледжі забезпечують своїх студентів різнобічною освітою з двома роками роботи за своєю спеціалізацією. Пропонуються також навчання для іноземців, які зобов'язані навчатись відмінно. Зазвичай ці навчальні заклади отримують більше заяв на навчання, аніж можуть набрати студентів.

Отримати ступінь (Graduate) стає можливим після 22 років. Тривалість навчання складає 2-10 років. Потрібно мати ступінь бакалавра (Bachelor's Degree). Після завершення навчання присвоюється ступінь Магістра Гуманітарних наук (Master of Arts - MA) або Доктора Філософрії (Doctor of Philosophy). Вартість навчання складає від 7000 до 29000 доларів за рік. Студенти, які навчаються відмінно, можуть отримати право на гранти від факультетів (Departmental Grants) чи стипендію (Followships). Серед особливостей навчання задля отримання освітнього ступеня Graduate знаходимо поєднання вивчення курсу і проведення самостійного дослідження і, як результат, - написання дисертації.

Отримати професійну (Professional) освіту можна у віці 22 років і старше. Тривалість навчання складає від 3 до 10 років. Мінімальною вимогою $€$ наявність ступеня бакалавра. Отриманий ступінь залежить від галузі (агрономія, медицина, право тощо). Вартість складає від 24000 за рік навчання. Після завершення середньої школи вступити до професійних шкіл (медичної, юридичної чи ветеринарної) $€$ неможливим, е необхідно мати диплом бакалавра (Bachelor's Degree).

Освіта США також пропонує короткострокові навчальні програми. Сюди включають неперервну освіту (Continuing Education). Університетські професійні асоціації забезпечують охочих отримати професійну освіту або перекваліфікуватись, або підвищити свою кваліфікацію семінарами та короткостроковими курсами для професіоналів усіх галузей. Тривалість таких курсів - тиждень або два, семінари тривають до трьох днів. Так звані напівнезалежні тренінгові інститути при навчальних закладах або при урядових інститутах пропонують навіть професіоналам 3-за кордону короткострокові тренінги у бізнесі та інших напрямках. Тривалість становить до одного року [4].

Щоб отримати ступінь магістра (Master's Degree), потрібно навчатись стаціонарно. Термін навчання - 1-3 роки. Існують дві магістерські програми професійні магістерські ступені та академічні дослідницькі магістерські ступені.

1. Професійні магістерські ступені (Professional Master's Degrees) передбачають доведення наявності компетенції у певній галузі, у формі проходження практики або стажування. Прикладом можуть слугувати Ступінь Магістра Бізнес Адміністрування MBA (Master of Business Administration), Магістр Освіти (Master of Education).

2. Академічні дослідницькі магістерські ступені (Research Master's Degrees) - це процес здобуття ступеня Доктора Філософії (PhD). Цей ступінь забезпечує досвідом здійснення дослідницької роботи та завершується процесом 
обов'язкової підготовки до захисту магістерської дисертації у фоомі кваліфікаційного іспиту. Наведемо приклади програм на здобуття магістерських ступенів: Магістр Гуманітарних Наук (Master of Arts - MA) та Магістр Природничих наук (Master of Science).

Програма на здобуття ступеня доктора фрілософії (PhD) передбачає підготовку науковця для роботи в конкретній сфері. Ступінь доктора вміщує в собі опанування курсом та написання докторської дисертації за конкретною спеціальністю. Термін навчання - 4-6 років на стаціонарі. Особливістю навчання у США $\epsilon$ те, що до складу деяких докторських програм входять програми на здобуття і магістерського ступеня, коли студенти можуть розпочинати навчання, отримавши ступінь бакалавра, хоча решта програм вимагають наявність магістерського ступеня перед початком програм навчання. Протягом першого та другого років навчання програма реалізується у формі проведення аудиторних занять. Мета таких занять - забезпечити опанування академічною теорією. Ті, хто навчається, обов'язково повинні скласти іспити та затвердити майбутній дослідницький проект. Проект готується до захисту 3 роки. Роль викладача у цьому процесі полягає у коректуванні формулювання мети дослідження і основних положень проекту, а наприкінці - в оцінюванні результатів проекту.

Вимоги до вступу на програми на здобуття освітніх ступенів (Graduate Study). Вимоги до вступу, як правило, сильно варіюються. Але зазвичай ретельно розглядають два останні роки навчання студента на переддипломній програмі (Undergraduate Study Program). Отже, аналіз літератури дозволив виокремити такі фактори:

- академічна успішність (бажано представити високі результати за переддипломне (Undergraduate) навчання);

- особиста інформація (Personal Statement) або аплікаційне есе (Application Essay);

- рекомендації (Recommendations / References);

- бали за тести (стандартизовані тести GRE, GMAT, TOEFL, TSE (за вимогою)) [4]. Під акредитацією розглядають систему для встановлення довіри громадськості та інструмент, який використовується навчальними закладами для свого вдосконалення та розвитку. Саме акредитація у США забезпечує базовий рівень якості у ВНЗ завдяки перевірці професорсько-викладацького складу, змісту курсів та інших процедур, які мають місце у закладах, де надається освітня послуга.

Мета акредитації у США полягає у:

- Забезпеченні якості освітніх програм завдяки використанню стандартів та конкретизованих критеріїв в оцінюванні;

- Стимулюванні навчальних закладів підвищувати якість освітніх послуг;

- Забезпеченні системи суспільної відповідальності та довіри з боку суспільства. Доходимо висновку, що мета акредитації США $є$ ідентичною 3 метою акредитації в Україні.

Володіючи інформацією про акредитацію вищого навчального закладу, можна дізнатися про рівень якості установи та її репутацію. В Україні діяльність освітніх закладів регулюється Міністерством освіти. У США функцію акредитації виконують акредитаційні організації. Саме вони і несуть відповідальність за присудження певного акредитаційного статусу. 


\title{
Список літературних джерел:
}

1. Романовський О. (1999). Особливості організації вищої освіти в США. Освіта і управління, (2), 160-170.

2. Де навчатись - у Канаді чи США? Відмінності у найкращих системах освіти Вилучено 3 https://iccnovar.com/blog/de-navchatys-u-kanadi-chy-ssha-vidminnosti-u-najkrashhyhsystemah-osvity/

3. Шанааха Алі Вища освіта в США. Massachusetts Institute of Technology. Вилучено з https://studfiles.net/preview/5768613/

4. Вища освіта у США: специфіка та процес вступу (2004). Київ: Видавничий дім «КМ Академія».

\section{DOI 10.36074/29.11.2019.v5.04}

\section{ОСОБЕННОСТИ ЭМПАТИЧЕСКИХ СПОСОБНОСТЕЙ И ВЫРАЖЕННОСТЬ ГЕНЕРАЛИЗОВАННОГО ТРЕВОЖНОГО РАССТРОЙСТВА У СТУДЕНТОВ МЕДИКОВ}

\author{
Строчка Олена Борисівна \\ ассистент кафедры внутренней медицины \\ Днепропетровская Государственная медицинская академия
}

УКРАИНА

Психоэмоциональная нагрузка, возникающая у студентов, обучающихся в высших учебных заведениях может приводить к различного вида астенизации и развитию тревожных расстройств. Причинами возникновения тревожности могут быть как факторы наследственности, здоровья, так и социальные - негативный жизненный опыт, нарушения во взаимоотношениях с родителями, учителями, сверстниками.

Для будущего врача профессионально-важным качеством является эмпатия, так как студенты-медики должны владеть такими личностными качествами, как сочувствие, сопереживание, эмоциональная чуткость, понимание психологических состояний других людей, потребности в общении, помощи другим людям.

Цель работы: выявить особенности развития эмпатических способностей и выраженность генерализованного тревожного расстройства у студентов медиков.

Материалы и методы исследования: обследовано 78 студентов ГУ «ДМА» 4 курса, лечебного фракультета. Все студенты, участвующие в исследовании были соматически здоровы. Время для тестирования было выбрано в начале практического занятия. Для опроса были использованы стандартные опросники: GAD-7, Spitzer RL et al. (A brief measure for assessing generalized anxiety disorder) и опросник глобальной оценки астении, который состоит из трех разделов, фризическая астения, интеллектуальная астения и психологическая астения. Каждый раздел содержит 5 признаков, оцениваемых испытуемым по оценке от 0 до 10 баллов (0 - отсутствие жалоб, 10 - максимальное проявление"[3]. Для исследования эмпатии была 
использованная методика В.В. Бойко "Диагностика уровня эмпатических способностей" [1]. В качестве методов математической обработки применялась описательная статистика, непараметрический критерий МаннаУитни (U).

В результате анкетирования была выявлена астения у 66 человек (84,6\%) из 78 опрошенных, при этом легкая степень выраженности астении у 47 студентов $(71,2 \%)$, умеренная - у 13 человек $(19,7 \%)$, тяжелая у 6 человек $(9,1 \%)$. Согласно формам астении, выявленные нарушения соответствовали: интеллектуальной астении - 61 человек (92,8\%), психологической астении - 5 человек $(7.2 \%)$, признаков фризической астении не выявлено. Наиболее часто тяжелая и умеренная астения выявлялась у студентов с высокой успеваемостью, в группе со слабым уровнем знаний умеренно выраженная астения была выявлена у 2 человек.

Наличие тревожного расстройства по результатам опросника выявлено у $32(41 \%)$ человек. Минимальный уровень тревожности из 32 студентов выявлен у $20(62,5 \%)$ студентов, умеренный - $5(15,6 \%)$ человек, средний - 3 $(9,3 \%)$ и высокий у $6(12,6 \%)$ студентов. Высокий и средний уровень тревожности наблюдался чаще у студентов с высокой и средней успеваемостью, минимальный в группе, со слабым уровнем знаний.

Высокий уровень рационального канала эмпатии был выявлен у 4 лиц $(5,1 \%)$, средний уровень развития рационального канала у $45(57,7 \%)$, низкий уровень развития у 29 студентов $(37,2 \%)$. По эмоциональному каналу емпатии: 15 (19,3\%) студентов были с высоким уровнем, $37(47,4 \%)$ исследуемых со средним уровнем развития эмоционального канала эмпатии, $26(33,3 \%)$ с низким уровнем развития. По интуитивному каналу эмпатии выявлено 16 (25,0\%) студентов с высоким уровнем, 32 (41,0\%) имели средний уровень эмпатии, $30(38,5 \%)$ низкий уровень. Установки, которые способствуют эмпатии: выявлено 30 (38,5\%) студентов с высоким уровнем, 42 $(53,8 \%)$ со средним уровнем, $6(7,7 \%)$ с низким уровнем. Проникающая способность эмпатии: у 40 (51,3\%), исследуемых имела низкий уровень, 38 $(48,7 \%)$ студентов, - средний уровень развития, с высоким уровнем развития проникающей способности к эмпатии студентов не выявлено. Идентификация - одно из непременных условий успешной эмпатии. По результатам $10(12,8 \%)$ человек имеют высокий уровень развития идентификации, $46(58,9 \%)$ студентов - со средним уровнем развития идентификации эмпатии, $22(28,2 \%)$ - с низким уровнем развития идентификации эмпатии.

Выводы: проведенное исследование демонстрирует наличие связи между эмоциональным состоянием студентов и уровнем успеваемости, указывает на необходимость выявления у учащихся психологических отклонений. Группой риска при возникновении астении, тревожных состояний, а в дальнейшем и депрессии могут быть более ответственные лица с высокой успеваемостью в учебе. У студентов был выявлен заниженный уровень эмпатии, высокий уровнь эмпатии встречается редко.

\section{Список используемых источников:}

1. Бойко, В. В. (1996). Энергия эмоций в общении: взгляд на себя и на других. Москва: Филин.

2. Пономарева, М. А. (2006). Эмпатия: теория, диагностика, развитие. Минск.

3. The GAD-7 is a valid and efficient tool for screening for GAD and assessing its severity in clinical practice and research. (2006). O ArchInternMed, (166), 1092-1097. 


\section{ОСОБЛИВОСТІ ВПРОВАДЖЕННЯ МЕТОДОЛОГІЧНИХ ПІДХОДІВ ДО УПРАВЛІННЯ ЯКІСТЮ ОСВІТИ В ШКОЛІ}

Ралько Ольга Володимирівна

заступник директора з освітньої діяльності Бердянська гімназія №1 «Надія» Бердянської міської ради Запорізької області

УKPÄ̈HA

Проблема управління якістю освіти в даний час набуває особливої актуальності. У Законі України Про загальну середню освіту визначаються положення загальної освіти, пов'язані зі створенням нормативної бази і необхідністю співвідносити результати фрункціонування освітніх систем із запитами суспільства. Однак, традиційні засоби вдосконалення оцінки якості знань, умінь і навичок учнів не відповідають сучасним вимогам.

Методологічні підходи, принципи у своїх дослідженнях з питань управління характеризують О. В. Вознюк (синергетико-кіберетичний), Э. М. Кайлюк (стратегічний), С.В.Королюк (культурологічний), В.В.Крижко (аксологічний), С. Г. Немченко (рефлексивний), В. Г. Никифоренко, Э. М. Хриков (системний) та інші. В контексті нашого дослідження зосередимо увагу з питань системного підходу на роботах М. П. Андрєєва, Т. І. Ільїної, Л. Берталанфрі, В. М. Садовського, Ю. П. Сокольникова, В. А. Штоффра та інші; людиноцентричного - Ю. А. Конаржевского, П. І. Третьякова, Т. І. Шамової та інших; компетентнісного - Д. А. Іванова, В.Д. Шадрикова та нших; технологічного - В. П. Беспалька, М. Є. Бершадського, В. В. Гузєєва, М.В.Кларіна, Г. К. Селевка, А. І. Умань та інших.

У філософській [9] і психолого-педагогічній літературі [2] якість освіти розглядається з різних позицій. Поняття «якість» в фрілософрії визначається як перевага, «суттєва визначеність предмета, в силу якої він $€$ даним, а не іншим предметом і відрізняється від інших предметів» [6]. Кращі стандарти $€$ показниками якості. У цьому визначенні якість $€$ рівнозначною властивості. Більш перспективними $€$ визначення якості освіти як заходи відповідності освіти заздалегідь встановленим вимогам або сукупність властивостей освіти, які обумовлюють його здатність задовольняти певні потреби громадянина, суспільства, держави відповідно до призначення цієї освіти.

Економічний сенс управління якістю освіти розкривається через цілеспрямований вплив на об'єкт управління за допомогою економічних, правових важелів, які використовують для отримання певних значень якісних показників.

Мета статті полягає в характеристиці методологічних підходів з питань управління якістю освіти в школі.

В даний час існує декілька підходів до управління якістю засвоєння знань, умінь і навичок учнів, які забезпечують зміну формального характеру управлінської діяльності, що виражається у прагненні керівників шкіл систематизувати і узагальнювати рішення проблем.

Таким є системний підхід (М. П. Андрєєв, В. М. Садовський, Ю. П. Сокольников, Т. І. Ільёна, В. А. Штоффф і ін.), який орієнтує на вивчення управлінського процесу як системи функцій. Реалізація функцій управління 
впливає на систему управління в цілому. Даний підхід дозволяє представити всі управлінські дії у взаємозв'язку. Тільки на його основі можливий настрій цілісної моделі управління школою 3 урахуванням всього різноманіття суб'єктивних і об'єктивних фракторів її розвитку.

Лео фон Берталанфі визначає систему як комплекс взаємопов'язаних елементів, що характеризуються цілісністю якісною визначеністю, структурністю, ієрархічністю, взаємозалежністю і взаємодією, константністю, динамічністю, відкритістю.

Аналіз відповідної літератури (Ю. К. Бабанський, А. Н. Леонтьєв, Ю.П. Сокольников) дозволяє виділити ряд ознак, завдяки яким системи можуть бути описані як цілісні утворення. До них відносяться:

- наявність сукупності елементів, кожен з яких представляє мінімальну одиницю, що має межу подільності в рамках даної системи. Елемент в складі системи виконує тільки одному йому властиву функцію, яка може бути реалізована за умови його взаємозв'язку з іншими елементами. Визначити елемент системи означає, перш за все, опис його структури, спосіб зв'язку компонентів його складових [2];

- наявність певних зв'язків і відносин між елементами. Спосіб взаємодії цих елементів в системі визначає ії структурну побудову. Поведінка системи, іï фрункціонування, властивості обумовлені не стільки поведінкою її окремих компонентів, скільки властивостями її структури;

- наявність інтеграційних якостей, тобто таких, якими не володіє жоден 3 окремо взятих елементів;

- наявність зв'язків з іншими системами. Крім загальних для всіх систем ознак, як специфічної властивості соціальних систем виділяється така ознака, як наявність цілей. Рівень цілісності системи залежить від повноти набору елементів, тісноти взаємозв'язку між ними, наявності цілей у всіх елементів та їх зв'язку з метою системи.

Однак існують причини, внаслідок яких при спробі застосувати дані підходи до реальних фрактів життя школи виникають значні труднощі:

1. Акцентування управлінських зусиль в основному на організаційноструктурних аспектах діяльності школи на шкоду змістовному аспекту.

2. Переважання принципу використання особистості в управлінні школою.

Включення фуннкції мотивації в управлінський цикл (В. С. Лазарєв, М. М. Поташник, П. І. Третьяков, Т. І. Шамова) створює суттєві передумови для усунення зазначеної причини. Разом з тим, слабка розробленість впливу на мотиваційну структуру соціально-педагогічної системи «школа» призводить до домінування одновимірних стратегій впливу на учасників освітнього процесу.

3. Домінування в школі режиму усунення наслідків відхилень від заданих параметрів розвитку освітнього процесу замість режиму запобігання збоїв в діяльності школи.

Цими причинами обумовлений той факт, що досить велике коло управлінських завдань залишається поза увагою керівника школи.

Іншим значущим для нас підходом до внутрішкільного управління $\epsilon$ ситуаційний підхід, предметом дослідження якого $€$ конкретна ситуація, зовнішні і внутрішні змінні, що впливають на неї. Цей підхід заснований на процесуальному підході, тому функції управління реалізуються стосовно конкретної ситуації взаємодії (М. Альберт, С. О'Доннел, Г. Кунц, М. Х. Мескон та інші). Однак ситуаційний підхід не розкриває сутність управління в цілому, 
оскільки передбачає лише конктетну діяльність за вибором методів управління з виявленими змінними конкретної ситуації. Управління в цьому випадку залишається зовнішнім, існуючим заради підтримки стабільності.

Математично обґрунтований аналіз ситуаційного управління дозволив В. В. Дружиніній і Д. С. Конторовій зробити висновок про те, що його завдання характерні для виробничих систем. Таким чином, ситуаційний підхід до внутрішкільного управління ефективний у випадках, пов'язаних з досягненням досить описаних не тільки якісних, а й кількісних результатів освітнього процесу (П. І. Третьяков).

Людиноцентричний підхід має предметом дослідження особистість людини керуючого і керованого (Ю. А. Конаржевский, П. І. Третьяков, Т. І. Шамова та інші). Прихильники даного підходу орієнтуються в його змісті на такі положення:

- основу діяльності керівництва школи складають повага до людини, довіра до нього, цілісний погляд на учня і вчителя, фрокусування уваги на розвитку особистості, створення ситуації успіху для учасників освітнього процесу;

- надання внутрішкільному управлінню координуючого мотиваційного характеру в цілому і, зокрема, в процесах комунікації і прийняття рішення;

- зміна погляду керівників шкіл на свою роль і місце в процесі управління. Не «пастух», «штовхач», «локомотив», який штовхає «вагон-колектив», а конструктор саморушного вагону, соціальний архітектор, який об'єднує волю окремих вчителів в єдину колективну» [5].

Реалізація людиноцентричного підходу у практиці роботи шкіл дозволяє вирішити багато управлінських проблеми, такі, наприклад, як формування сприятливого соціально-психологічного клімату в школі, стимулювання діяльності учасників освітнього процесу. Людиноцентричний підхід - нова парадигма внутрішкільного управління, що припускає серйозні зміни традиційних поглядів не тільки на змістовний аспект управління, але і на вирішення питань технології управлінської діяльності.

Однак механізми реалізації людиноцентричного підходу до управління якістю щодо надання освітніх послуг, розроблені, на нашу думку, недостатньо. Тому доцільно використовувати мотиваційний підхід, націлений на практичну реалізацію людиноцентричну підходу (П. І. Третьяков, І. К. Шалаєв, Т. І. Шамова та інші). Призначення даного підходу полягає у формуванні такого психолого-педагогічного механізму, який забезпечує ефективну діяльність всіх учасників освітнього процесу (П. І. Третьяков). Мотиваційне програмно-цільове управління, розглядається як цілеспрямований вплив суб'єкта управління на мотиваційну сферу підлеглого не у вигляді наказів і санкцій, а за допомогою норми-зразка діяльності, при якому мотиваційна сфера перебудовується адекватно до поставленої управлінської мети.

Алгоритм мотиваційного програмно-цільового управління наступний:

1. Постановка управлінського завдання або визначення бажаного кінцевого результату.

2. Розробка цілей мотиваційно-виконавчої програми, у якій на основі загальних якісних характеристик визначається конкретний план дій виконавців.

3. Обробка і реалізація мотиваційно-управлінської програми як продукту інтеграції традиційного управлінського циклу з соціально-психологічної стратегією і тактикою [1]. 
У роботах В. С. Лазарєва і П. І. Третьякова отримало подальший розвиток мотиваційне управління в зв'язку з розглядом мотивації як функції в естетичному вихованні управління школою (керівництво, мотиваційно-цільова функція).

Відповідно до сучасних психологічних уявлень, рівень умотивованості людини на досягнення якихось результатів визначається трьома параметрами: оцінкою досяжності результату, оцінкою очікуваних наслідків при досягненні цих результатів, оцінкою корисності наслідків. Саме тому, надаючи завдання підлеглим, адміністрація школи повинна переконатися, що вони: добре розуміють, яких результатів від них чекають; впевнені, що зможуть отримати ці результати; бачать позитивні наслідки для себе від участі в діяльності і оцінюють їх як більш значущі, ніж можливі негативні наслідки (В.С. Лазарєв.).

У роботах Т. І. Шамовой і П. І. Третьякова ефективність мотиваційного управління пов'язується зі створенням умов для реалізації «в повному обсязі всіх компонентів людського "само"» [5].

Оскільки школа - складна система, що самоорганізується. I з об'єктивних причин стає значущим, що їй не можна насильно нав'язувати шляхи розвитку, які впливають на певні внутрішні потреби, тому проблема керованого розвитку школи набуває форму проблеми самоврядного розвитку.

Компетентнісний підхід у філософській та психолого-педагогічній літературі отримав свій розвиток у зв'язку згідно вимог Болонського процесу. У словнику іноземних слів компетентнісний (лат. Competens (competentis) - відповідний здатний) визначається як той, хто володіє компетенцією або знає і усвідомлює власні дії в певній галузі. В. Д. Шадриков розглядає компетентнісний підхід в залежності від чотирьох компонентів: знання, вміння i навички, які використовуються в діяльності; здібності, особистісні якості і компетенції.

На думку Д. А. Іванова, компетентнісний підхід в освіті передбачає «засвоєння учнями різного роду умінь, що дозволять їм в майбутньому діяти ефективно в ситуаціях професійного, особистісного і громадського життя» [3]. Особливе значення приділяється умінням, які дозволяють діяти в нових, невизначених проблемних ситуаціях. У зв'язку з цим, компетентнісний підхід $\epsilon$ зусиллям прикладного, практичного характеру всієї шкільної освіти. Перелік необхідних компетенцій визначається запитами ринку праці та соціологічними дослідженнями. Основна мета і результат процесу навчання $€$ оволодіння різного роду компетенціями.

Це передбачає принципові зміни в організації навчального процесу, в управлінні ним, в способах оцінювання освітніх результатів учнів в порівнянні з навчальним процесом, заснованим на концепції «засвоєння знань». У цьому відношенні опис компетенцій, які можуть бути використані в будь-яких ситуаціях стає принциповим, тому що основною цінністю стає не засвоєння учнями сукупності інформації, а засвоєння компетенцій, які дозволяли б їм визначати цілі, діяти в нестандартних ситуаціях. При такому підході, на думку Д. А. Іванова, принципово буде змінюватися позиція педагога. Фактично він повинен створити умови, «розвиваюче середовище», в якому стає можливим вироблення кожним учнем, на рівні розвитку його здібностей, визначених компетенцій в процесі докладання зусиль в напрямку поставлених цілей.

У психолого-педагогічній літературі немає також чіткого визначення понять «компетенція» і «компетентність».

Ключові параметри ринку праці, 
розробки стандартів освітніх програм та навчальних планів Європейський фонд освіти (ЄФТ), 1997 визначає компетенцію як «1. Здатність робити щонебудь добре або ефрективно. 2. Відповідність вимогам, що пред'являються при влаштуванні на роботу. 3. Здатність виконувати особливі трудові функції. Дане визначення поняття «компетенція» може розглядатися в двох напрямках: 1) як інтегральна особистісна якість людини; 2) опис складових його діяльності, що дозволяє йому успішно впоратися із вирішенням проблем.

Нам близька позиція А. П. Тряпиціної і В. Д. Шадрикова, що розглядають компетенції як характеристику діяльності, тобто в основу компетенції покладена теорія діяльності.

Класиффікація компетенцій містить в собі три класи:

1. Професійні - необхідні для реалізації професійної діяльності фрахівця;

2. Надпрофесійні - необхідні для ефективної роботи в організації;

3. Ключові, в які входять вміння та якості, необхідні для успішної соціалізації.

Спочатку необхідно сформулювати склад ключових компетенцій, потім визначається зміст конкретних умінь, що входять в основну компетенцію, якими повинні володіти учні і виробити критерії, за якими можна судити про рівень їх досягнення. Як приклад оцінювання компетенцій можна привести програму «Ключові компетенції 2000», розроблену спільно з Оксфордським і Кембриджських університетами, і опис деяких тестових матеріалів PISA (Ключові компетенції 2000, програма OCR. RECOGNISING ACHIEVMENT, Oxford Cembridge and RSA Examinations).

Найважливіше місце в дослідженнях в рамках проекту PISA приділено блоку «Рішення проблем», адже в умовах реального життя компетентність у вирішенні проблем $\epsilon$ основою для подальшого навчання, ефективної майбутньої професійної діяльності, організації особистого життя. При роботі 3 текстами, діаграмами, графіками і таблицями учню потрібно проявити такі вміння загального інтелектуального характеру: наводити аргументи; виробити свою точку зору і обґрунтувати ії; вибрати найбільш виважену аргументацію; вміння отримувати потрібну інформацію; узагальнювати факти і робити висновки; порівнювати об'єкти або інформацію; аналізувати наявні факти; розрізняти думку і факти; здійснювати вибір з кількох альтернатив; шукати закономірності на основі фрактів; визначати причини вчинків людей або явищ.

Технологічний підхід виступає як концентроване вираження досягнутого рівня розвитку. Стосовно освіти він передбачає точне інструментальне управління навчальним процесом i гарантоване досягнення поставлених навчальних цілей.

В даний час технологічний підхід розробляється В. П. Беспалько, М. Є. Бершадським, В. В. Гузєєвим, М. В. Кларін, Г. К. Селевко, А. І. Умань та ін. В основі даного підходу покладено педагогічну технологію, розуміння якої до теперішнього часу розглядається 3 різних позицій. М. Бурголь, В. П. Кузовлев, В. Н. Монахов, Ю. Подурецкі [1] визначають педагогічну технологію як мистецтво, майстерність викладача і вихованців; як продуману модель спільної педагогічної діяльності з проектування, організації та проведення навчального процесу. У нашому дослідженні ми спираємося на дану точку зору. Технологічний підхід передбачає розкриття і опис основних характеристик педагогічної технології. У своїх дослідженнях ми спираємося на структуру, що включає: сутність, яка відображатиме головну проблему; цільові 
орієнтації; концептуальну основу, тобто короткий опис керівних ідей, принципів, що сприяють розумінню трактування ії побудови і функціонування; організаційні особливості, тобто зміст і структуру; процесуальну характеристику; навчально-методичне забезпечення, класифікаційну характеристику.

Таким чином, внутрішкільне управління - це складний процес і тому його осмислення може здійснюватися 3 різних точок зору, використовуючи розглянуті підходи для вирішення певного кола управлінських завдань. Розглянуті підходи орієнтовані на досить чітке виділення фрормальної структури управління, наявність якої обумовлює можливість жорсткої алгоритмізації внутрішкільного управління.

Таким чином, наявність алгоритмів управління забезпечує у шкільній практиці ефективне рішення однотипних проблем, що мають циклічний характер. Існує цілий ряд причин, внаслідок яких при спробі застосувати дані підходи до реальних фрактів життя школи виникають значні труднощі. Нами визначено головні з них:

1. Акцентування управлінських зусиль в основному на організаційно структурних аспектах діяльності школи на шкоду змістовному аспекту.

2. В рамках проблемно-орієнтованого підходу зроблена спроба вийти в змістовний аспект діяльності школи за допомогою виділення основних проблем. Однак недостатня розробленість критеріїв оцінки значущості виявлених проблем, переважання жорсткої алгоритмізації в управлінні у постійно мінливих зовнішніх умовах ускладнює реалізацію цього підходу в практичній діяльності.

3. Включення функції мотивації в управлінський цикл, що створює суттєві передумови для усунення зазначеної причини. Разом з тим слабка розробленість механізмів впливу на мотиваційну структуру соціальнопедагогічної системи «школа» в рамках розглянутих підходів призводить до домінування щодо їх реалізації в управлінській практиці одновимірних стратегій впливу на учасників освітнього процесу, в основі яких покладено монологічний тип взаємодії.

4. Домінування в школі режиму усунення наслідків відхилень від заданих параметрів розвитку освітнього процесу замість режиму запобігання збоїв в діяльності школи.

Цими причинами обумовлений той факт, що досить велике коло найрізноманітніших управлінських завдань залишається поза увагою керівника школи, про що й буде йти мова в подальших наших розвідках.

\section{Список використаних джерел:}

1. Бугдоль, М., Кузовлев, В.П., Подгурецки, Ю. (2004). Соціальні питання в управлінні якістю. Ополе-Елец.

2. Гончаренко, С.У. (1997). Український педагогічний словник. Київ: Либідь.

3. Давиденко, Т. М. (1989). Управління діяльністю вчителів щодо формування у школярів знань із заздалегідь заданими властивостями (автореф. дис. канд. пед. наук ). Москва, Російська Федерація.

4. Іванов, Д. А. (2008). Компетенції і компетентнісний підхід в освіті. Управління сучасною школою. Завуч, (1).

5. Про загальну середню освіту (Закон України). №651-XIV. (2008). Вилучено 3 https://zakon.rada.gov.ua/laws/main/651-14 
6. Філософський енциклопедичний словник. Вилучено 3 http://catalog.odnb.odessa.ua/opac/index.php?url=/notices/index/ldNotice:24375/Source:defaul

\section{ОСОБЛИВОСТІ МЕТОДОЛОГІЧНОГО АНАЛІЗУ ДОСЛІДЖЕНЬ ВПЛИВУ РІЗНИХ ФОРМ ТЕСТОВИХ ЗАВДАНЬ НА РЕЗУЛЬТАТИ ТЕСТУВАННЯ}

Гривко Антоніна Вікторівна

канд. пед. наук, ст. наук. співробітник відділу моніторингу та оцінювання якості загальної середньої освіти Інституту педагогіки НАПН України

УКРАЇНA

Теоретико-методологічним особливостей конструювання тестового інструментарію для оцінювання здобувачів загальної середньої $€$ вивчення актуальних наукових пошуків, сукупність яких формує методологію теоретико-практичних засад тестування.

Аналіз праць дав змогу зробити висновки про те, що наявність суперечливих поглядів різних науковців (зокрема про еквівалентність складності й діагностичної потужності тестових завдань закритих і відкритих форм ([1], [2]), наявність або відсутність впливу структури тестів на результати тестування ([3], [4]), доцільність використання моно- або поліформатних тестів для підсумкового оцінювання ([5], [6]) та ін.) визначається складністю досліджуваного питання та методичними особливостями проведення експериментів.

Так, М. Кастна і Б. Штангл [7] проаналізували численні дослідження пов'язані 3 визначенням, наскільки еквівалентними $€$ тестові завдання 3 множинним вибором і завдання з конструйованою відповіддю. Дослідниці дійшли висновку, що причиною відсутності однозначної думки науковців щодо цього питання $є$ зіставлення результатів наукових пошуків без урахування таких складників методики проведення досліджень, як особливості інструментарію (зокрема, конкретизація типу завдань певної форми) та оцінювання результатів (зокрема, застосовувані правила оцінювання поліформатних тестів).

Водночас, детальне вивчення методики проведення дослідження дає змогу виявити недоліки й запобігти помилок у подальших наукових пошуках. Для прикладу розглянемо дослідження впливу різних форм тестових завдань на числові показники відповідей учнів (тестові бали) [8], здійснене на підґрунті зіставлення результатів Єдиного державного екзамену за 2014 - 2016 рр. щодо виконання завдань із вибором однієї правильної відповіді та завдань, на які їх було замінено, - 3 декількома правильними відповідями та 3 конструйованими відповідями. За висновками дослідників, заміна фооми тестових завдань за умови незмінності оцінюваного конструкту (знання або вміння) практично не впливає на статистичні характеристики тестів: відповідно 
до проведеного аналізу складність завдань підвищилася неістотно, як і незначною мірою покращилася їх розподільча здатність [8]. Однак, на нашу думку, такі висновки $€$ недостатньо емпірично обґрунтованими 3 декількох причин. По-перше, за словами авторів, у представленому ними документальному дослідженні порівняння результатів виконання завдань різних фрорм було здійснено з похибками, оскільки порівнювались результати різних вибірок, а зміст аналізованих завдань був нетотожним. По-друге, результати представленого аналізу не дають змоги зробити узагальнені висновки про вплив фрорми завдання на статистичні характеристики тесту, оскільки, окрім змісту, вони диференціюються ще й за складністю передбачуваних для їх розв'язання дій (операційна складність): порівняймо, наприклад, завдання на заповнення пропусків і завдання на пояснення; завдання з вибором однієї правильної відповіді на запитання (перевіряють знання певного теоретичного конструкту) і завдання, які передбачають, що для вибору однієї правильної відповіді необхідно ще прочитати текст або виконати певні дії (знання і застосування теоретичного конструкту) - цей аспект у розглянутому дослідженні не враховано.

Виявлення недоліків у методиці проаналізованого дослідження зумовило врахування їх нами при вивченні впливу поєднання різних форм тестових завдань на результати тестування учнів 8 і 9 класів із української мови. Зокрема, аналіз когнітивної складності паралельних завдань різних форм дав можливість обґрунтувати й врахувати наявність залежності результатів виконання цих завдань від операційно-діяльнісного компонента їх складності. Так, вирішення завдань на встановлення відповідності (використані в тестах разом із паралельними завданнями інших форм) характеризуються циклічною повторюваністю мисленнєвих операцій і пов'язаним із цим зменшенням варіативності вибору потрібних дескрипторів, що підвищує вірогідність «здогадки». Цю тезу підтверджує аналіз зіставлення результатів тестування (рівень виконання завдань на встановлення відповідності в кожному разі вищий за рівень виконання паралельних завдань із множинним вибором однієї та декількох варіантів відповіді та завдань із конструйованими відповідями) та результатів аналізу впливу поєднання завдань різних форм у тесті: у кожному з поєднань, сила впливу яких на результативні показники сягає до 35\%, що є свідченням зниження діагностичної точності результатів тестування, присутні завдання на встановлення відповідності.

Отже, у процесі огляду наукових праць, пов'язаних із вивченням впливу різних форм тестових завдань на результати тестування, аналіз висновків їхніх авторів часто $€$ недостатнім. Виявлення причин неоднозначних висновків за різними дослідженнями, спрямованими на вивчення одних і тих самих питань тестології, уможливлює детальне вивчення усіх складників методики проведених експериментів (інструментарій, процедура його застосування, оцінювання та методи аналізу результатів дослідження).

\section{Список використаних джерел:}

1. Hancock, Gregory, R. (1994). Cognitive Complexity and the Comparability of Multiple-Choice and Constructed-Response Test Formats. The Journal of Experimental Education, 62/2, 143-157. DOI: 10.1080/00220973.1994.9943836 
2. Melovitz, Vasan, Ch. A., DeFouw, D. O., Holland, B. K., \& Vasan, N. S. (2018). Analysis of testing with multiple choice versus open-ended questions: Outcome-based observations in an anatomy course. Anat Sci Educ, 11:3, 254-261. https://doi.org/10.1002/ase.1739

3. Дятлова, К. Д. (2006). Исследование влияния разнообразия форм тестовых заданий на статистические характеристики теста. Вопросы тестирования в образовании, 4, $65-75$.

4. Решетникова, О.А. (2016). Что оказывает влияние на изменение контрольных измерительных материалов для государственной итоговой аттестации. Педагогические измерения, 2, 5 - 9 .

5. Marengo, D., Miceli, R., \& Settanni, M. (2016). Test unidimensionality and item format: Do mixed item formats threaten test unidimensionality? Results from a standardized math achievement test. Testing, Psychometrics, Methodology in Applied Psychology, 23:1, March, 25-36.

7. Kan, A., Bulut, O. \& Cormier, D. C. (2019). The Impact of Item Stem Format on the Dimensional Structure of Mathematics Assessments. Educational Assessment, 24:1, 1332, DOI: $10.1080 / 10627197.2018 .1545569$

8. Kastner, M., \& Stangl, B. (2011). Multiple Choice and Constructed Response Tests: Do Test Format and Scoring Matter? Procedia - Social and Behavioral Sciences, 12, 263-273. doi:10.1016/j.sbspro.2011.02.035.

9. Полежаева, М.В., Нурминский, А.И., Орехова, С.В., Полежаев, В.Д. (2018). Влияние формы задания на его статистические характеристики (на примере контрольных измерительных материалов ЕГЭ). Педагогические измерения, 3, 97 - 108.

\title{
ОСОБЛИВОСТІ НАВЧАННЯ ХУДОЖНЬОМУ ТКАЦТВУ НА ТЕРЕНАХ ПІВНІЧНО-СХІДНОЇ УКРАÏНИ XIX - ПОЧАТКУ XX CT.
}

\begin{abstract}
Гулей Ольга Володимирівна
заслужений майстер народної творчості України, старший викладач кафедри образотворчого мистецтва, музикознавства та культурології Сумський державний педагогічний університет імені А. С. Макаренка

УКРАÏHA
\end{abstract}

Зазначимо, що навчання ткацтву в XIX - на початку XX століття в ПівнічноСхідній Україні відбувалося поза межами звичних інституційних форм i починалося від 14-15 років, що було зумовлено розмірами ткацького верстата. Початок навчання відбувався після досягнення відповідного зросту та рівня фізичного розвитку учня (учениці): як тільки ноги дитини діставали до підніжок. Особливістю навчання ткацького ремесла, в основному, було спостереження за роботою матері й виконання самостійних спроб наслідування практичних вправ [1]. За спогадами кролевецького ткача Гринь від п'яти років діти були в ткацтві, сам Гринь навчався ткати у матері. До 13-ти років «сукав цівки», а від 13-ти почав навчатися ткати складні малюнки [2]. Підтвердження вікової періодизації навчання дітей у сім'ї ткачів знаходимо у праці В. ДоливоДобровольської: «Діти з шести, семи років починали сукати цівки, деякі вже з десяти років сідали за верстат» [3].

Наразі, крім сімейної форми, в досліджуваний період в Північно-Східній Україні навчання ткацтву також проходило у формі учнівства у досвіченого 
майстра. Наприклад, за архівними даними, у 1855 році серед ремісників міста Кролевець Роменського повіту ткачів було 150, підмайстрів - 20, учнів - 35. 3а даними А. Карася, за наступні 35 років кількість ткачів і їх учнів збільшилася у 8 разів при зростанні населення лише у двічі [4]. Це пояснюється збільшенням попиту на кролевецькі вироби. Доцільно вказати, що на початок XX століття ткачі означеного регіону майже зовсім відмовились від землеробства. Як стверджує $Є$. Спаська, в сім'ї на цей період ткацьким ремеслом займалися усі працездатні члени родини: жінки, чоловіки й діти [5].

Відтак, у Північно-Східній Україні другої половини XIX - початку XX століття ткацтву навчали переважно вдома, в сім'ї, або віддавали в науку до досвіченого майстра. Від кінця XIX століття деякі ткачі почали залишати своїх учнів робітниками на річну оплату: підліток отримував 5-6 крб, дівчина, котра уміла ткати - 10-12 крб, ткач - 30-35 крб на рік. Господар годував, а взуття та одяг робітник повинен був мати свої [3].

Отже, позаінституційне навчання художньому ткацтву на теренах ПівнічноСхідного регіону України означеного періоду відбувалося у формі сімейного навчання й виховання та індивідуально, у формі праці у досвіченого майстра.

\section{Список використаних джерел:}

1. Кісь, О.Р. (2012). Жіноча історія як напрямок історичних досліджень: становлення феміністської методології. Український історичний журнал, (2), 159-172.

2. Шевченко, Л. П. (1950). 3 історії Кролевецької промартілі «XX-річчя Жовтневої революції» (до 1917 р.): рукопис. (Кн. 1: запис № 1-21). АІМФЕ НАН України.

3. Доливо-Добровольская, В. А. (1894). Ткацкий промысел в Грайворонском и Кролевецком уездах. Отчеты и исследования по кустарной промышленности России. (Т. 2: cс. 80-88). Санкт-Петербург: Тип. В. Киршбаума.

4. Карась, А. В. Роль земства у розвитку ткацтва. Збереження історико-культурних надбань Сіверщини: матеріали четвертої науково-практичної конферениії (сс. 135-138). 21-22 квітня 2005, Глухів, Україна: РВВ ГДПУ.

5. Спаська, Є. Ю. (1959). Про рушники: рукопис. АІМФЕ НАН України.

\section{ОСОБЛИВОСТІ СИСТЕМИ ДОШКІЛЬНОЇ ОСВІТИ В БЕЛЬГІЇ}

Прохорчук Віра Андріївна

Педагогічний інститут Київського університету імені Бориса Грінченка

Науковий керівник: Кошарна Н.В. канд. пед. наук

Педагогічний інститут Київського університету імені Бориса Грінченка УКРӒ̈НА

Дослідженням проблеми навчання та виховання дітей дошкільного віку в Європейських країнах опікувалось багато вчених та педагогів-практиків В. Зебзеєва, С. Дудко, Л. Литвин, Т. Поніманська, Л.Козак, Н. Карпенко, Н. Мельник, М. Олійник, тоді як вивчення питання дошкільної освіти в Бельгії 
досі залишається відкритим, що й зумовило актуальність вибору теми наукового дослідження.

Структура системи освіти Бельгії охоплює чотири рівні: дошкільний вік (від 2 до 6 років); початковий (6 - 12 років); середній (12 -18); вища освіта 3 програмами тривалістю від 2 до 7 років. Специфіка системи освіти Бельгії обумовлена структурою самої держави, який визначається трьома рівнями, включає Федеральну державу, Фламандський, Валлонський та Брюссельський столичні регіони та спільноти - фламандська, французька та німецькомовна громади [2]. Зважаючи на мультилінгвальність Брюсельського мовного регіону, діти дошкільного віку вивчають французьку, голландську та німецьку мови.

Фламандська система освіти включає в себе дитячу (nursery) і початкову (primary) освіту для дітей віком від 2,5 до 12 років. У французькій громаді система освіти включає дитячі школи (nursery school), які відвідують діти від 2,5 до 6 років. До систем освіти німецькомовної громади належать ясла-садок (nursery school) для дітей віком від 3 до 5-6 [1].

Установи, які забезпечують дошкільну освіту в Бельгії, фінансуються державою, проте у згаданій структурі немає стандартизованої навчальної програми, багато дошкільних закладів пов'язані з початковими школами і зосереджені на підготовці до початкової освіти. Дошкільні заклади та початкові школи часто діляться будівлями та іншими приміщеннями. Деякі школи пропонують спеціальну дошкільну освіту для дітей з особливими потребами.

Безкоштовне дошкільне навчання (голландська: kleuteronderwijs; французька: enseignement maternel; німецька: Kindergarten) надається кожній дитині віком від 2 до 6 років. У більшості регіонів дитина може починати відвідування закладу дошкільної освіти, як тільки досягає цього віку, тому розмір групи для найменших дітей зростає упродовж року. Варто зазначити, що офіційно затверджених занять у дитячому садку немає, будь-яке навчання відбувається у формі гри.

Оскільки дошкільна освіта для дітей $2-6$ років є частиною системи освіти в Бельгії, загальні цілі, викладені в Указі про початкову школу [3], застосовуються як для закладів дошкільної освіти, так і для початкових шкіл. Цілі включають підтримку та сприяння соціально-емоційній, інтелектуальній, психомоторній та мистецькій сферах навчання. Законодавство здебільшого також діє як для дитячих садків, так і для початкових шкіл.

Конституцією Бельгії закріплено право на загальну освіту, підкреслюючи цінність свободи освіти та принцип рівності можливостей незалежно від статі, раси, етнічної приналежності чи віросповідання.

Метою системи дошкільної освіти у Бельгії $€$ навчити дітей дошкільного віку бути творчими і самостійними, розвивати їх пізнавальні здібності засобами гри, формувати навички спілкування у колективі, зберігаючи при цьому їх індивідуальність і неповторність.

\section{Список використаних джерел:}

1. Florian, Geyer. (2009). The Educational System in Belgium CEPS Special Report, Integrated Project of the European Commission's 6th Framework Programme "Citizens and governance in a knowledge-based society". Retrieved from http://aei.pitt.edu/14575/1/lncluded_FG_on_Ed_System_in_Belgium.pdf 
2. Gillian, Golden. (2017). Education Policy Outlook Belgium, OECD. Retrieved from http://www.oecd.org/education/Education-Policy-Outlook-Country-Profile-Belgium.pdf

3. Указ про початкову школу Бельгії. (1999). Вилучено з https://www.etaamb.be/fr/decret-du-26avril-1999_n1999033086.html

\section{DOI 10.36074/29.11.2019.v5.05}

\section{ПОСАДА ЯК ЧИННИК ВІДМІННОСТЕЙ У ПРОФЕСІЙНОМУ МИСЛЕННІ ПЕДАГОГІВ}

Лукіна Тетяна Олександрівна

докт. наук з держ. упр., професор, головний науковий співробітник відділу моніторингу та оцінювання якості загальної середньої освіти Інститут педагогіки Національної академії педагогічних наук України

УКРӒ̈НA

Кожна сфера діяльності людини поступово формує специфічне професійне мислення, що являє собою певний набір специфічних прийомів вирішення проблемних завдань, способів аналізу професійних ситуацій та прийняття відповідних професійних рішень. Не є виключенням і сфера освіти. Вченими досліджуються різні аспекти проблеми формування професійного, у т.ч. педагогічного мислення. Наприклад, М.М. Кашапов під професійним мисленням педагога розуміє сукупність характеристик, що «мають значення для продуктивності і цілеспрямованості виконання педагогічної діяльності» [5]. О.А. Орлов, розкриваючи сутність професійного мислення вчителя як цінності, зазначав, що воно характеризується неперервністю і постійною включеністю у практичну діяльність. Осмислення та наступне пояснення певної педагогічної ситуації, на думку дослідника, здійснюється педагогом на основі наявних у нього наукових знань та особистого досвіду [10]. М.М.Марусинець тлумачить сутність поняття «професійне мислення» з позиції рефлексії та саморефлексії. При цьому особливу увагу автор приділяє залежності залежність успіху професійної діяльності вчителя від рівня розвиненості професійного мислення у процесі розв'язанні навчальних та педагогічних задач [9]. O.V. Dysa досліджує особливості розвитку професійного мислення і доводить, що процес смислоутворення, як певний етап професіогенезу, відбувається під впливом різноманітних зовнішніх та внутрішніх чинників професійної діяльності [2].

Активно вивчаються питання, пов'язані з структури та особливостей формування професійного мислення педагога у залежності від його спеціальності [4].

JL. Хуан здійснив аналіз досліджень з проблеми формування та удосконалення професійного мислення педагога. Автор зазначає, що мислення вчителя є звичкою і стратегічним процесом збору інформації, її відображення, розуміння, вирішення проблем, прийняття рішень, ініціювання дій та накопичення практичної мудрості [11]. К. Дей у своїй праці стверджував, що для підтримки високого професіоналізму педагог повинен регулярно переглядати практику своєї роботи, а також шукати відповіді на питання «чому?» з погляду моральності та розумності [1]. 
Таким чином, професійне мислення і професійна діяльність тісно пов'язані між собою через певну проблемну ситуацію, яка одночасно виступає i професійною задачею, і предметом професійної діяльності. Вирішення цієї проблемної ситуації породжує творчий мисленевий процес. Розуміння та оцінювання ситуації, що виникає і потребує осмислення, здійснюється на основі професійного досвіду особистості, а значить, залежіть від характеру, особливостей і спрямованості професійної діяльності, у т.ч. посади як певного службового становища, що пов'язане з виконанням відповідних обов'язків.

Раніше в контексті вивчення різних аспектів запровадження компетентністного підходу до навчання, нами досліджено проблему сформованості оціночної компетентності педагогів [6], їх готовності до зміни методики проведення ДПА випускників гімназій [8], особливостей розуміння вагомості та призначення окремих функцій оцінювання [7].

Мета проведеного нами емпіричного дослідження полягала у виявленні відмінностей у розумінні педагогами основного призначення та способів використання результатів складання державної підсумкової атестації (ДПА) здобувачів базової загальної середньої освіти (випускників гімназій) у формі зовнішнього незалежного оцінювання (3НО) як певного прояву особливостей професійного педагогічного мислення. Основним інструментом виступала анкета. У дослідженні брали участь 47 методистів (М), 109 директорів закладів загальної середньої освіти (Д) та 73 вчителя різних спеціальностей (В).

В основу даного дослідження було покладено припущення, що посада педагогів впливає на прояв відмінностей їх професійного мислення. Ці відмінності будуть також проявлятися і при визначенні та оцінюванні ними різноманітних нововведень в системі освіти. Зокрема, досліджувалося припущення про те, що розуміння різними категоріями респондентів (методистами, директорами та вчителями) основного призначення ДПА у формі ЗНО та способів використання результатів її складання випускниками гімназій має відмінності, що обумовлені особливостями їх професійного мислення, яке формується посадою, тобто специфікою та вимогами посадових обов'язків педагогів.

Для опрацювання результатів дослідження було використано програмний пакет «Аналіз даних» MS Excel. Кожна позиція у таблицях (табл. 1 та табл. 2) обчислювалася як частка обраних відповідей від загальної можливої кількості відповідей у кожній групі респондентів, ХัХер - середнє значення часток.

Для з'ясування думок педагогів щодо найголовнішого призначення ДПА учасники опитування мали обрати по одному із запропонованих варіантів відповіді: а) виявляти реальний рівень навчальних досягнень учнів; b) сприяти вибору певного профілю навчання у старшій школі; с) здійснювати відбір учнів для елітного навчання; d) звичайне річне оцінювання.

Таблиия 1

Розподіл думок респондентів щодо найголовнішого призначення ДПА у формі ЗНО здобувачів базової загальної середньої освіти

\begin{tabular}{|c|c|c|c|c|}
\hline $\begin{array}{c}\text { Категорія } \\
\text { педагога }\end{array}$ & A & b & c & d \\
\hline Методисти (М) & 0,489 & 0,319 & 0,021 & 0,17 \\
\hline Директори (Д) & 0,45 & 0,358 & 0,278 & 0,193 \\
\hline Вчителі (В) & 0,548 & 0,26 & 0,055 & 0,137 \\
\hline Хсер & 0,496 & 0,3123 & 0,118 & 0,167 \\
\hline
\end{tabular}

[авторська розробка] 


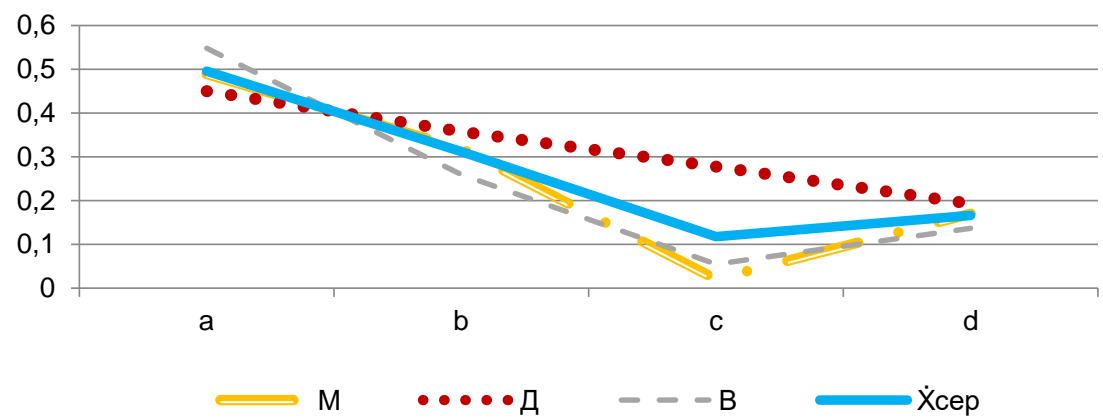

Рис. 1. Розподіл відповідей різних категорій педагогів щодо основного призначення ДПА у формі ЗНО

3 рис. 1 бачимо, що у педагогів переважає думка про те, що основне призначення ДПА для випускників гімназій полягає у виявленні реального рівня навчальних досягнень учнів (варіант а). Відповідно до концепції освітньої реформи, ДПА для випускників гімназій має забезпечити вибір того чи іншого профрілю навчання учня у старшій школі. Однак, у ході дослідження виявлено, що саме цей варіант формулювання найголовнішого призначення ДПА не викликав належної уваги з боку практично усіх груп посад педагогів (див. табл.1).

Незначні відмінності виявлено у виборі варіанту $d$ (звичайне річне оцінювання). Цікавим, на нашу думку, результат щодо вибору варіанта с) (здійснювати відбір учнів для елітного навчання). Методисти і вчителі продемонструвати схожість думок, а от директори надали йому суттєву перевагу.

Виявлено кореляцію між розподілом посад педагогів та варіантами відповідей за спадаючим характером $r=-0,0128$. Застосування однофакторного дисперсійного аналізу виявило наявність певного впливу посади педагога на визначення ними основного призначення державної підсумкової атестації у формі ЗНО здобувачів базової середньої освіти. Критерій Фішера $F(3,86)=6,41$ при $p=0,012<0,05$.

Сила впливу фактора посади (за Снедекером) [3] $\eta^{2}=5,458515284$.

Наступне завдання полягало виявленні впливу посади педагога на визначення ним способів використання результатів складання ДПА у формі ЗНО випускниками гімназій. Для цього учасникам анкетування пропонувалося обрати свій варіант відповіді серед запропонованих: а) учень має бути прийнятий до 10 класу незалежно від результату атестації; b) учень повинен перескласти ДПА на більш високий бал, щоб навчатися у 10 класі; с) учень відраховується зі школи; d) учень без свідоцтва про здобуття базової середньої освіти зараховується у 10 клас; е) учень зараховується до вирівнювального класу без свідоцтва про здобуття базової середньої освіти. 
Розподіл думок респондентів щодо найбільш доцільних способів використання результатів складання ДПА у формі ЗНО здобувачів базової загальної середньої освіти

\begin{tabular}{|c|c|c|c|c|}
\hline $\begin{array}{c}\text { Категорія } \\
\text { педагога }\end{array}$ & $\mathrm{a}$ & $\mathrm{b}$ & $\mathrm{c}$ & $\mathrm{d}$ \\
\hline Методисти (М) & 0,213 & 0,404 & 0,255 & 0,064 \\
\hline Директори (Д) & 0,248 & 0,303 & 0,532 & 0,156 \\
\hline Вчителі (В) & 0,123 & 0,37 & 0,356 & 0,096 \\
\hline Хссер & 0,195 & 0,359 & 0,381 & 0,105 \\
\hline
\end{tabular}

[авторська розробка]

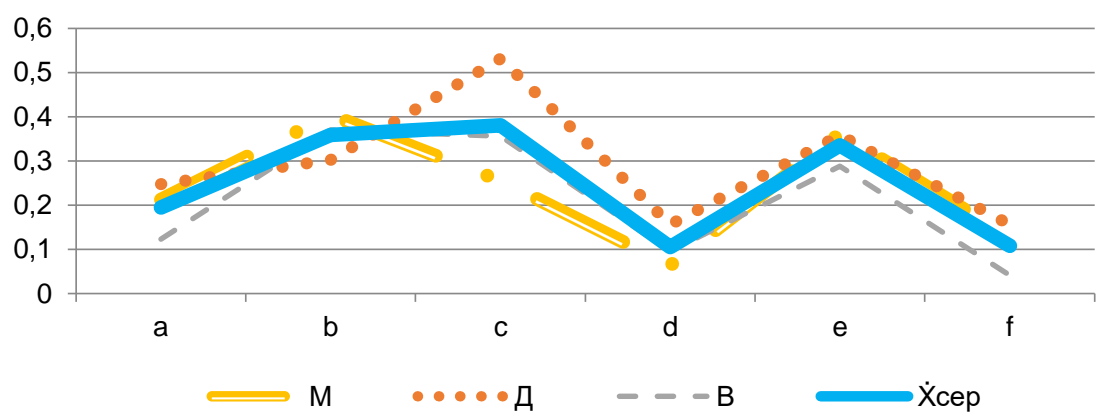

Рис. 2. Розподіл відповідей педагогів різних посад щодо найбільш доцільних способів використання результатів складання ДПА у формі ЗНО здобувачів базової $3 \mathrm{CO}$

Критерій Фішера $(3,86)=49,78$ за умови $p=<0,000$. Виявлено кореляцію $r=-0,0517$. Це свідчить про наявність достатньо сильного впливу посади педагога на вибір ними способу використання результатів складання ДПА у разі отримання здобувачем базової ЗСО низьких результатів оцінок.

Сила впливу посади як чинника визначення способу використання результатів складання підсумкової атестації (за Снедекером) [3]: $\eta^{2}=55,89$.

Висновки. Таким чином, виявлений статистично значущий вплив посади педагогів на розуміння ними деяких концептуальних позицій державної підсумкової атестації у формі зовнішнього незалежного оцінювання здобувачів базової середньої освіти, зокрема тих, що стосуються основного призначення цієї атестації та визначення за ії результатами подальшої освітньої траєкторії учнів, дає можливість розглядати посаду як один з чинників, які формують відмінності у професійному мисленні педагогів.

\section{Список використаних джерел:}

1. Day, C. (2002). Developing teachers: The challenges of lifelong learning. Landon, UK: Routledge.

2. Dysa O.V. (2015). Психологічні механізми та чинники розвитку професіійного мислення. Journal of Psychology Research, (T. 21: 9/1). Вилучено 3 http://www.psyresearch.dp.ua/index.php/psy/article/view/151

3. Snedecor, George W. (1937). Statistical Methods Applied to Experiments in Agriculture and Biology, Ames, IA: Collegiate Press. 
56 • Problèmes et perspectives d'introduction de la recherche scientifique innovante $\bullet$ Volume 5

4. Білосевич, І.А. (2011). Технічне мислення, як складова професійного мислення майбутнього вчителя технологій. Науковий вісник Ужгородського національного університету. Серія "Педагогіка, сощіальна робота“", (23), 16 - 18.

5. Кашапов, М. М. (2000). Психология педагогического мышления. Санкт-Петербург: Алетейя.

6. Лукіна, Т.О. (2013). Запровадження компетентнісного підходу до оцінювання якості освіти учнів в Україні: виклики та перешкоди. Анотовані результати науково-дослідної роботи Інституту педагогіки НАПН України за 2013 рік. (с. 106-107). Київ: Педагогічна думка.

7. Лукіна, Т.О. (2014). Компетентність педагога як передумова запровадження компетентністного підходу до оцінювання якості освіти учнів. В Ляшенко, 0.І.\& Жук, Ю.О. (ред.) Тестові технології оцінювання ключових і предметних компетентностей учнів основної і старшої школи. (с. 28 -45). Київ: Педагогічна думка. Вилучено з: http://undip.org.ua/news/library/monografii_detail.php?ID=3053.

8. Лукіна, Т.О. (2019). Проблеми підготовки педагогів до зміни методики проведення державної підсумкової атестації випускників основної школи. Компетентнісно орієнтоване навчання: виклики та перспективи: зб. тез I Всеукраїнської науково-практичної інтернетконференції (с. 68-69). 30 вересня 2019 р., Київ, Україна: Педагогічна думка. Вилучено з: ttp://undip.org.ua/news/library/zbirniki_detail.php?ID=9303

9. Марусинець, М. М. (2014). Професійне мислення вчителя: рефлексивний аспект. Актуальні проблеми соціології, психології, педагогіки, (23). Вилучено 3 http://apspp.soc.univ.kiev.ua/index.php/home/article/view/269

10. Орлов, А. А. (2006). Профессиональное мышление учителя как ценность. Тула: Изд-во ТГПУ.

11. Хуан, J. L. Educ Res Policy Prac (2015) 14: 247. https://doi.org/10.1007/s10671-015-9184-1.

DOI 10.36074/29.11.2019.v5.06

\section{ПРО ЛІНГВОДИДАКТИЧНІ ОСНОВИ РОБОТИ НАД КУЛЬТУРОЮ МОВЛЕНННЄВОГО СПІЛКУВАННЯ УЧНІВ}

Сокаль Марія Анатоліївна канд. філолог. наук, доцент, завідувач кафедри слов'янського мовознавства ДЗ «Південноукраїнський національний педагогічний університет імені К. Д. Ушинського

Зобенкова (Просвіріна) Світлана Олександрівна здобувач вищої освіти фракультету початкового навчання ДЗ «Південноукраїнський національний педагогічний університет імені К. Д. Ушинського УКРӒ̈̈А

Культура мовленнєвого спілкування, як показує аналіз наукової літератури, $€$ актуальним предметом лінгводидактичних досліджень (Т. Городілова, В. Капінос, Т. Ладиженська, Н. Ладиженська, М. Соловейчик, Г. Сорокіна, І. Стернін та ін.). Цій проблемі присвячені роботи провідних вітчизняних лінгвістів і методистів - Н. Бабича, О. Бобиря, М. Жовтобрюха, А. Каніщенко, Г. Коваль, Л. Мацько, А. Мовчун та Л. Мовчун, О. Пономарьової, 
О. Савченко, Л. Соловець, Л. Хоружей,О. Хорошковської та ін. Вони вивчають мовну культуру літературного мовлення, лінгвоекологічні питання, пов'язані 3 мовною ситуацією, мовним середовищем і мовною політикою, культурологічні питання, що стосуються історії виникнення мовленнєвого етикету, питання формування навичок культури мовлення у дітей в умовах шкільного навчання та сімейного виховання та ін.

Т. Городілова вважає, що в теорії навчання мовам, тобто лінгводидактиці, необхідно враховувати всі сторони мовленнєвого спілкування і розглядати його і як процес взаємодії. Відомо, що комунікативний процес мовленнєвого спілкування починається із встановлення психологічного контакту. Це відкриває шлях до смислового контакту і вищого рівня комунікації безпосереднього спілкування. Якщо $є$ розбіжність особистісних смислів, процес спілкування згортається. За Т. Городіловою, мовленєве спілкування це «відношення, що відкладається на основі змісту інформації друг до друга» [2]. У цьому аспекті в лінгводидактиці розробляється функціональний підхід до навчання, реалізується принцип свідомо-комунікативного навчання, використовується коммунікативно-пізнавальний метод.

Здатність до спілкування, на думку канд. пед. н. О. Кияченко, містить у собі:

- бажання вступати в контакт із навколишніми («Я хочу»);

- знання норм і правил, яких необхідно дотримуватись у спілкуванні 3 навколишніми («Я знаю»);

- уміння організувати спілкування («Я вмію») [3].

Для взаєморозуміння, на основі якого відбудеться спілкування, необхідно, щоб учасники спілкування розуміли не тільки зміст висловлювання, але й ситуацію спілкування, заради якої висловлюється сама думка. Тому завдання педагога - навчити дітей спілкуватися, взаємодіяти один з одним, розвивати необхідні вміння і навички спілкування.

Теоретична основа навчання культури мовленнєвого спілкування - це дисципліни, предметом вивчення яких $є$ мовлення. Поняття «мовлення» $€$ міжпредметним: воно розглядається в лінгвістиці, психологічній, психолінгвістичній, педагогічній літературі.

«Сучасний етап розвитку мовознавства характеризується як новими підходами до вивчення мови - невід'ємної частини повсякденного життя людини та процесів її спілкування, так і класичними, з-поміж яких і донині перспективними залишаються комунікативна лінгвістика (Ф.С.Бацевич, В. В. Богданов, П. Грайс, С. П. Денисова, А. А. Зернецька, С. М. Іваненко, О. С. Іссерс, А. В. Корольова, Ю. В. Косенко, Г. Г. Почепцов, О. О. Селіванова, І. І. Серякова, Й. А. Стернін та ін.) та прагматика з її теоріями мовленнєвих актів (Л. О. Азнабаєва, Н. Д. Арутюнова, Дж. Браун, Д. Вандервекен, Т. Т. Врабель, Дж. Гюль, М.К. Джибрин, А. В. Дедухно, В. Загерак, В.ІІ. Карабан, В.І. Карасик, Ю. В. Микитюк, Дж. Л. Остін, Дж. Р. Серль, Р. В. Серебрякова, І. П. Сусов, Н. А. Трофимова, Д. О. Фадіса, І. С. Шевченко та ін.)», - констатує Н. В. Павлик у своєму дисертаційному дослідженні [5].

Лінгвісти, як правило, пишуть про мовлення в плані його зіставлення 3 мовою: мовлення розглядають як реальний вид існування мови, його живу й безпосередню реалізацію. Лінгвістика мовлення має своїм об'єктом усі ті типізовані явища, які пов'язані з учасниками комунікації та обставинами спілкування, тобто з прагматичною стороною мовлення. Прагматичну сторону мовлення становлять компоненти мовленнєвої ситуації, всі ті немовні 
фактори й обставини, без яких мовленнєвий акт не може відбутися: мовець суб'єкт і адресат, обстановка мовленнєвого спілкування і той фрагмент об'єктивної реальності, про яку робиться повідомлення [4].

Подібне розмежування мови і мовлення є важливим для методики. Опираючись на нього, методисти розрізняють вивчення системи мови і вивчення функціонування мови; вивчення системи мовних понять і вивчення функціонування, застосування, використання мовних засобів. На цій основі розглядається зміст роботи 3 формування культури мовленнєвого спілкування молодших школярів.

Як зазначає І. Х. Стіліану, в процесі удосконалення мовленнєвої культури учнів першочергового значення треба надавати мові, меті мовлення, умовам спілкування і мовленнєвій ситуації. «Функціонально-стилістична мета мовлення передбачає добір оптимальних мовних засобів відповідно до потреб висловлювання. Соціально-психологічні умови спілкування визначають толерантне ставлення мовця до співбесідника, зумовлене віком, соціальним становищем, вимогами норм ввічливості тощо». Зумовленим екстралінгвістичними обставинами компонентом спілкування $є$ мовленнєва ситуація. Вона «зумовлює не тільки зміст, обсяг, синтаксичну організацію, але й форму мовлення, зокрема його темп, висоту тону, паузи тощо. Мовленнєва ситуація $€$ органічним компонентом спілкування, у багатьох випадках вона виступає і як засіб комунікації» [7].

Необхідно враховувати, що робота з розвитку навичок культурного мовленнєвого спілкування починається в сім'ї, але здобуває цілеспрямований, систематичний характер тільки із приходом дитини в школу. Саме в початковій школі закладаються основи культури мовлення i, ширше, увічливості, гарних манер, уміння жити в колективі, культури поведінки в громадських місцях і под., тобто комунікативної культури в цілому.

Відомо, що сформованість основних рис культури поведінки особистості тісно пов'язана із внутрішньою культурою людини. Саме форми зовнішньої поведінки відображають моральні цінності, естетичні потреби, ставлення до існуючих суспільних норм. Моральною основою спілкування $\epsilon$ доброзичливість і повага однієї людини до іншої. Складність розвитку навичок культурного спілкування (у тому числі мовленнєвого) у молодших школярів обумовлена тим фрактором, що внутрішні регулятори культури, система ставлення до навколишнього, моральні цінності в цьому віці тільки починають формуватися - порівн. несформованість емоційно-вольової сфрери учня початкової школи (невміння стримувати свої бажання, емоції), недостатній досвід соціальної поведінки, вплив негативних зразків поведінки (вулиця, телебачення, можливо - сім'я) і наслідування їм та ін. «Основними педагогічними методами формування знань у школярів про культуру поведінки є роз'яснення, позитивні приклади і зразки з художньої літератури та життя...», - пише д. пед. н. Л. Хоружа [8].

Об'єктом досліджень методистів $€$ мовлення як предмет навчання, саме тому вони, як правило, кажуть про «розвиток мовлення» 3 навчальнопедагогічної точки зору, на відміну від психологів, які теж уживають цей термін і яких цікавить насамперед сам процес становлення мовлення.

Методика розвитку мовлення має давню історію. Сучасний етап її розвитку спирається на досягненнями лінгвістичної науки в нових галузях (теорія лінгвістики тексту, психолінгвістика, зокрема, теорія мовленнєвої 
діяльності - О.О. Леонтьєв) і спробами об'єднати системно-описовий і комунікативно-діяльнісний підходи в початковому курсі мови (див. [1]).

Мовленнєвий етикет відносно недавно (в останні десятиріччя 20 ст.) був уведений у курс методики навчання молодших школярів, насамперед у зв'язку з розробкою нового напрямку - розвитку мовлення як засобу спілкування (роботи Т. Ладиженської, А. Маркової, О. Сороцкої та ін., порівн. книгу «Речь. Речь. Речь» Т. Ладиженськой (з'явилась у 70-х роках минулого століття), де широко представлені завдання, пов'язані із мовною етикою, а пізніше розробку колективом авторів під ії керівництвом навчальних посібників «Детская риторика» для початкової школи. У кожному розділі підручника $€$ матеріал для роботи над мовленнєвим етикетом. В українській школі як варіативна складова початкового навчання пропонується курс «Риторика» (автори - В. Науменко і М. Захарийчук).

Таким чином, сучасний шкільний учитель має наукову основа для викладання, орієнтованого на розвиток комунікативних умінь учнів, формування доречної (адекватної ситуації) мовленнєвої поведінки. У перспективі, на думку академіка М. С. Вашуленка, найактуальнішим $€$ таке лінгводидактичне завдання: побудова шкільного курсу мови як єдиного курсу теорії висловлювання (ідея російського психолога А. Маркової) - див. [1]. А завдання сьогоднішнього дня - формування й удосконалення вмінь і навичок висловлюватися і спілкуватися, володіти мовою у всіх тих сферах і видах мовленнєвої діяльності, які доступні молодшим школярам. I тут недостатньо просто знань мовної теорії, яка традиційно є предметом шкільного вивчення. Використання мови як засобу спілкування актуалізує ще й знання основних соціальних, ситуативних, контекстуальних правил, яких повинні дотримуватися всі носії мови, розуміння того, чому? Для чого? Коли? Де? Що саме? Як варто говорити в тих або інших ситуаціях. Дотримуючись загальнодидактичного принципу доступності, вчитель має ознайомити учнів із нормами комунікації і, головне, навчити учнів користуватися ними в реальній щоденній мовленнєвій діяльності (див. [1]).

3 огляду на вищевикладене, у роботі з культури мовлення можна виділити три основні моменти:

1) робота над правильністю творення мовних одиниць, тобто над мовними нормами;

2) робота над правильністю вживання мовних одиниць із урахуванням вимог контексту, тобто над мовленнєвими нормами; $[6])$.

3) роботи над комунікативно-доцільним уживанням мовних засобів (див.

\section{Список використаних джерел:}

1. Вашуленко, М. С. (2006). Українська мова і мовлення в початковій школі. Київ: Освіта.

2. Городилова, Т. Г. (1988). Развитие общения и проблемы лингводидактики. Русский язык в школе, (5), 41-45.

3. Кияченко, Е. А. (2002). Учим детей общаться. Начальная школа, (6), 63-67.

4. Ярцева В. Н. (ред.) (1990). Лингвистический энциклопедический словарь. Москва: Советская энциклопедия.

5. Павлик, Н. В. (2001). Коммуникативна та структурно-семантична організація фатичних мовленнєвих актів в англійській та українській мовах (на матеріалі драматичних творів кіния XIX - початку XX століть). [Дис. канд. філол. наук]. Національний педагогічний університет ім. М. П. Драгоманова, Київ. 
6. Соловейчик, М. С. (1986). Работа по культуре речи на уроках русского языка. Начальная школа, (7), 21-25.

7. Стіліану, І. Х. (2011). Культура мовлення старшокласників як лінгвістичне поняття в методологічному апараті підручника. Проблеми сучасного підручника, (11), 367-372.

8. Хоружа, Л. (2007). Формуємо культуру поведінки молодших школярів. Початкова школа, (2), 52-57.

DOI 10.36074/29.11.2019.v5.07

\section{ПРО ПРОФЕСІЙНЕ СТАНОВЛЕННЯ МАЙБУТНЬОГО ВЧИТЕЛЯ ПОЧАТКОВИХ КЛАСІВ}

Соколова Ганна Борисівна

доктор психологічних наук, доцент кафедри дефектології та фрізичної реабілітації ДЗ «Південноукраїнський національний педагогічний університет імені К. Д. Ушинського

Сокаль Світлана Анатоліївна здобувач вищої освіти Інституту фізичної культури, спорту та реабілітації Д3 «Південноукраїнський національний педагогічний університет імені К. Д. Ушинського

УКРӒ̈̈A

Модернізація та розвиток системи освіти в України, реформування системи навчання в напрямі інклюзії, забезпечення рівних прав на освіту для всіх дітей, формування загальноєвропейського освітнього простору робить особливо актуальними питання якісної професійної підготовки педагогів.

Досліджуючи процес підготовки майбутнього вчителя початкових класів науковці торкаються широкого кола питань: фрілософрії освіти, теоретикометодичних основ підготовки, методів та засобів професійної підготовки (А. Алексюк, В. Бондар, В. Бутенко, С. Гончаренко, О. Дубасенюк, А. Капська, А. Линенко, Л. Масол, Г. Падалка, О. Пєхота, О. Ростовський, О. Рудницька, Л. Савенкова, О. Савченко, В. Тименко, О. Шевнюк, О. Щолокова, Б. Юсов та ін.), системи психолого-педагогічної та методичної підготовки (К. Авраменко, Н. Дем'яненко, О. Кульчицька, О. Пономарьова, С. Сисоєва, Л. Хомич та ін.), формування професійних якостей, творчої активності студентів, готовності до різних видів діяльності (О. Антонова, О. Бабченко, В. Борисов, Л. Гусейнова, Г. Ніколаї, В. Шульгіна та ін.).

У педагогічній літературі рівні розвитку і професійного становлення особистості педагога визначаються у системі понять «підготовка» «готовність»

- «компетентність» - «педагогічна майстерність» - «професійна зрілість».

Готовність до діяльності педагога формується у процессі професійної підготовки. Отже, підготовка майбутнього вчителя розглядається як процес, а готовність - це, з одного боку, мета, а з другого - результат цього процесу (див. [1]). Професійна готовність майбутнього вчителя - це особистісна якість, що проявляється: 
- в позитивній самооцінці себе як суб'єкта майбутньої профеесійної діяльності;

- в прагненні займатися педагогічною діяльністю після закінчення 3 ВО. Вона дозволяє молодому фахівцю:

- успішно здійснювати свої професійні обов'язки;

- правильно використовувати набуті знання та вміння;

- бороти неочікувані перешкоди;

- успішно зд'йснювати самоконтроль.

Професійна готовність $€$ вирішальною умовою швидкої адаптації випускника до умов праці, та передумовою його подальшого професійного зростання (див. [2]).

Професійна підготовка педагогічних кадрів для початкової освіти $€$ специфрічною, оскільки учитель початкової школи має забезпечувати предметне навчання у різноманіх галузях: мовно-літературній, математичній, природничій, технологічній, інформатичній, громадянській та історичній, соціальній та здоров'язбережувальній галузях (за Державним стандартом початкової освіти), а також здійснювати різноманітну позакласну та позашкільну роботу. Це робить необхідним вироблення в майбутнього вчителя цілого комплексу різноманітних педагогічних умінь.

«Поняття «педагогічне вміння» означає володіння педагогом гнучкою системою усвідомлених, цілеспрямованих, взаємопов'язаних розумових і практичних дій, які дозволяють учителю успішно виконувати освітні функції в умовах, що змінюються. <..> Сутність педагогічного вміння полягає в оволодінні теоретичними і практичними діями в їх єдності, спрямованими на успішне виконання професійної діяльності» і виявляється через внутрішні (психологічні) і зовнішні (педагогічні) складові [3].

Отже, педагогічні вміння $є$ необхідними для професійної реалізації, та оскільки діяльність вчителя початкової школи поєднує багато складових, то і педагогічні вміння його мають бути комплексними, орієнтованими на вирішення комплексу навчально-виховних завдань. Такі вміння $є$ цілісним утворенням - ієрархічно взаємопов'язаною та взаємозумовленою сукупністю вмінь, що дозволяє забезпечити ефективну взаємодію вчителя з усіма суб'єктами навчально-виховного процесу. «Сутність комплексних педагогічних умінь полягає в оволодінні найбільш узагальненими, визначальними вміннями, що забезпечує їх широкий «перенос» на всю багатофункціональність діяльності вчителя початкових класів» [4]. Комплексні педагогічні вміння структурно співвідносяться з основними напрямами та фунціями роботи вчителя. Основний пласт цих вмінь пов'язаний з урочною роботою в учнівському колективі: навчальною та виховною діяльністю педагога. Але, окрім цього, до комплексу вмінь входять ще й такі, що забезпечують позаурочну виховну роботу з учнями, просвітницьку та організаційну роботу з батьками, професійну комунікацію з колегами вчителями, ділове спілкування з адміністрацією, зв'язки із громадськістю (див. про це $[3 ; 4])$.

Педагогічно доцільними фракторами (умовами) ефективного формування комплексних педагогічних умінь (за О. Острянською) є такі:

- зовнішня, загальна, пізнавальна, умова: усвідомлення студентами поняття, сутності, структури і видів педагогічних умінь, необхідних учителю початкових класів; 
- зовнішня, загальна, процесуально-організаційна умова: організація процесу і розроблення засобів особистісно орієнтованого фрормування комплексних педагогічних умінь;

- зовнішня, загальна, змістова умова: забезпечення педагогічно доцільної відповідності теоретичної і практичної підготовки майбутнього вчителя у процесі фрормування комплексних педагогічних умінь.

- різного роду внутрішні (мотиваційні, перцептивні, креативні) умови, зокрема, пов'язані із самоактивізацією студентів в освітньому процесі (див. [4]).

Від дотримання педагогічних умов залежить ступінь засвоєння студентами професійно орієнтованих знань, усвідомленість доцільності профресійних умінь, нестандартність застосування комплексних педагогічних умінь, творчий підхід до педагогічної діяльності (див. [3]).

Найбільш поширеним на сучасному етапі розвитку професійної освіти $€$ компетентнісний підхід. Головним результатом освіти в аспекті компетентнісного підходу визнається здатність до дії, до мобілізації необхідних в кожній конкретній ситуації наявних знань і досвіду, уміння використовувати знання на практиці. Це не означає, що нівелюється значення теоретичної підготовки, знань. Значущим визнається результат освіти поза межами освіти, у реальній практиці, а не те, що вивчили та запам'ятали (це лише передумови професійної готовності). Компетентність - це інтегрований результат освіти (див. [5; 6] та ін.).

Професійна компетентність є основою педагогічної майстерності - так характеризують рівень педагогічної діяльності, що ґрунтується на високому фаховому рівні педагога, його загальній культурі та педагогічному досвіді (див. [7]). За визначенням академіка І. Зязюна, засновника наукової школи 3 проблем педагогічної майстерності, відомого організатора вітчизняної вищої педагогічної освіти, «педагогічна майстерність - це комплекс властивостей особистості, що забезпечує самоорганізацію високого рівня професійної діяльності на рефрлексивній основі». Вона $€$ найвищим рівнем педагогічної діяльності, виявом творчої активності особистості педагога [8].

Педагогічна майстерність може удосконалюватись, її компоненти мають різні рівні прояву, вона - покажчик професійного розвитку вчителя, викладача, найвищим етапом якого $€$ професійна зрілість. Остання $€$ вершиною всієї життєдіяльності людини, результатом найвищої професіоналізаціі педагога, завершальним етапом його професійного розвитку та удосконалення, відображенням його найвищих досягнень, максимальних можливостей (див. [9]).

Отже, етапи (періоди) професійного становлення педагога - від його фахової підготовки в період навчання, та протягом подальшої педагогічної діяльності можливо представити у вигляді вертикального, спрямованого вгору вектора, що складається с відрізків професійна підготовка - професійна компетентність - професійна майстерність - професійна зрілість. Кожен 3 етапів характеризує певний рівень готовності до педагогічної діяльності.

\section{Список використаних джерел:}

1. Мішко, М. В. (2018). Організаційно-педагогічні умови формування готовності майбутніх учителів початкової школи до використання інтерактивних технологій навчання: Сучасні тенденції розвитку науки і освіти в умовах поглиблення євроінтеграційних процесів: 
збірник тез доповідей II Всеукраїнської науково-практичної конференції (с. 139-141). 1718 травня, 2018, Мукачево, Україна: Вид-во МДУ.

2. Гудзь, К. (2018). Готовність педагога до роботи в умовах інклюзивної освіти ЗНЗ. Педагогічний часопис Волині, (1(8)), 128-133.

3. Ярема, Н. В. Педагогічні умови формування комплексних педагогічних умінь у майбутніх учителів початкової школи: Сучасні тенденції розвитку науки і освіти в умовах поглиблення євроінтеграційних процесів: збірник тез доповідей II Всеукраїнської науково-практичної конференції (с. 239-241). 17-18 травня, 2018, Мукачево, Україна: Видво МДУ.

4. Острянська, О. (2000). Сутність і структура комплексних педагогічних умінь учителя початкових класів. Постметодика, (6 (32)), 25-28.

5. Яценюк, Л. (2018). До питань формування інклюзивної компетентності педагогів у контексті модернізації системи початкової освіти. Педагогічний часопис Волині, (1(8)), 168-170.

6. Зимняя, И. А. (2003). Ключевые компетенции - новая парадигма результата обучения. Высшее образование сегодня, (5), 34-42.

7. Гончаренко, С.У. (1997). Український педагогічний словник. Київ: Либідь.

8. Зязюн, І. А., Крамущенко, Л. В., Кривонос, І. Ф. (2004). Педагогічна майстерність. (2-е вид.). І. А. Зязюн (ред.). Київ: Вища школа.

9. Чайковський, М. (2012). Інклюзивна компетентність як складова професійної компетентності суб'єктів навчально-виховного процесу. Педагогіка $і$ професіійної освіт, (2), 15-21.

\section{ПРОФЕСІЙНА КОМПЕТЕНТНІСТЬ У ПІДГОТОВЦІ МАЙБУТНЬОГО ВЧИТЕЛЯ ТРУДОВОГО НАВЧАННЯ ТА ТЕХНОЛОГІЙ}

Великдан Юлія Віталіївна старший викладач кафедри теорії та методики технологічної освіти та комп'ютерної графіки ДВНЗ «Переяслав- Хмельницький ДПУ ім. Г.Сковороди»

УКРÄ̈̈A

Освіта в країні $€$ важливим стратегічним ресурсом для соціальноекономічного розвитку, яка повинна орієнтуватися на якісну підготовку молодого фахівців відповідно до змін, що відбуваються на ринку праці та гнучко реагувати на всі процеси, що відбуваються в світі. Якісний рівень освіти $\epsilon$ необхідною умовою для забезпечення економічного зростання держави, розв'язання соціальних проблем суспільства та розвитку особистості. Тому підготовка молодого вчителя в сучасному інформаційному суспільстві $\epsilon$ важливим педагогічним питання, і одним 3 елементів цієї підготовки $\epsilon$ використання компетентнісного підходу, який спрямований на підвищення освіченості студентів не за рахунок накопичення знань, що швидко змінюються, а саме здатністю використовувати набуті знання у сучасних реаліях як професійного, так і особистого життя. 
Формування професійної компетентності вчителя трудового навчання та технологій розглядається нині як невід'ємна складова реформи системи вищої педагогічної освіти в цілому, тому основна мета ЗВО передбачає підготовку такого освіченого фахівця, який має необхідні педагогічні знання, уміння i навички не лише технічного характеру а й певний рівень соціальнопрофесійної мобільності, конкурентоздатності на ринку праці та в різних сферах виробничої і педагогічної діяльності відповідно до потреб суспільства. У зв'язку з цим, у закладах вищої освіти під час усього навчально-виховного процесу гостро постає проблема підготовки професійно компетентних педагогів.

Кожний заклад вищої освіти створює оптимальні умови для надання якісних освітніх послуг, забезпечує якісну підготовку майбутніх фрахівців згідно компетентнісного підходу, спрямованого на фрормування компетентностей особистості, необхідних для майбутньої професійної діяльності. Основними характеристиками майбутнього вчителя мають стати професіоналізм, компетентність, самоорганізація, креативність, суспільний інтерес до компетентнісного підходу. Адже, професійна компетентність вчителя - це сукупність його особистісних якостей, загальної культури та кваліфікаційних знань, умінь, методичної майстерності, гармонійна інтеграція яких в педагогічній діяльності дає оптимальний результат.

Набуття вчителем професійної компетентності полягає в тому, що професійне знання має формуватися водночас на всіх рівнях: методологічному, теоретичному, методичному, технологічному. Це потребує розвиненого професійного мислення, здатності добирати, аналізувати і синтезувати здобуті знання в досягненні педагогічної мети, цілісно уявляти технологію їх застосування. Складові компоненти професійної компетентності, запропоновані О. Біляковським формують ідеального професіонала, що уособлює суспільні запити й потреби, відображає вимоги до вчителя сучасної школи. Розглянемо основні компоненти [1]:

- Методична компетентність включає засвоєння педагогом нових методичних і педагогічних ідей, підходів до навчально-виховного процесу в сучасних особистісно-зорієнтованих, розвивальних, креативних технологіях, володіння різними методами, прийомами і формами організації навчання.

-Психолого-педагогічна компетентність охоплює володіння психологопедагогічною діагностикою; уміння здійснювати індивідуальну роботу на основі результатів педагогічної діагностики, виявляти особистісні особливості школярів, визначати і враховувати емоційний стан людини, грамотно вибудовувати взаємовідносини з колегами, учнями, батьками

- Інформаційно-технологічна компетентність передбачає вміння і навички роботи з ІКТ; застосовувати раціональні прийоми пошуку, аналізу, адекватного відбору, систематизації, використання інформації; самостійно створювати різноманітні тестові завдання; враховувати дидактичні принципи, закономірності, способи, форми організації навчального процесу для його оптимізації на основі комп'ютеризації; дохідливо й чітко викладати навчальний матеріал $з$ огляду на специфіку предмета, суб'єктний досвід школярів, рівень їхньої підготовки, життєвий досвід і вік; уміння перебудовувати за необхідності план і хід викладу навчального матеріалу. 
- Полікультурна компетентність містить знання педагогом культурних, національних надбань, менталітету представників різних національностей, досягнень та звершень українського народу; толерантне ставлення до культури і традицій представників інших народів.

- Загальнокультурна компетентність передбачає досягнення високого рівня розвитку у суспільному, професійному й духовному житті; освіченість у галузі викладання предмета, високої ерудиції та культури поведінки тощо.

Розвиток професійної компетентності - в руках самого вчителя, оскільки він усвідомлено регулює стандарти своєї поведінки на основі набутого педагогічного досвіду. «Досвід стає джерелом професійного зростання вчителя лише тією мірою, якою вона є об'єктом структурованого аналізу: нерефлексований досвід безкорисний і з часом веде не до розвитку, а до професійної стагнації вчителя» (М. Уолес). Тільки усвідомлений досвід має сенс, через аналітичну діяльність здійснюється рефлексія, яка перетворює «сирий» досвід у особистісне присвоєне знання. У процесі рефлексії відбувається усвідомлення не тільки свого педагогічного досвіду, але й досвіду інших педагогів. Професійному зростанню вчителя й підвищення рівня його професійної компетентності сприяють: високий духовно-моральний імідж навчального закладу, що забезпечують сприятливі творчі умови роботи; систематична самоосвітня діяльність вчителя, яка включає навчання на курсах підвищення кваліфікації; участь у проектах, конкурсах, фестивалях, конференціях, семінарах, педагогічних майстернях, роботі методичних об'єднань, творчих груп тощо; особистісно-зорієнтована методична підтримка діяльності вчителя; акцент на інноваційному, творчо-пошуковому компоненті методичної діяльності; об'єктивна оцінка праці; моральне й матеріальне стимулювання [2].

Отже, професійна компетентність вчителя трудового навчання та технологій - це інтегрована властивість особистості, що володіє комплексом професійно значущих для вчителя якостей, має високий рівень науковотеоретичної й практичної підготовки до творчої педагогічної діяльності та ефективної взаємодії з учнями в процесі педагогічної співпраці на основі впровадження сучасних технологій для досягнення високих результатів.

Впровадження в освіту України компетентнісного підходу, обумовлюється підготовкою випускника на вдале працевлаштування, на його стимулювання до набуття та постійного поглиблення потрібних компетентностей.

\section{Список використаних джерел:}

1. Ціпан, Т. С. (2016). Професійна компетентність сучасного вчителя. Інноватика у вихованні, (3), 174-181.

2. Біляковська, О. О. (2012). Професійна компетентність учителя як складова ефективної педагогічної діяльності. Науковий вісник Мелітопольського державного педагогічного університету. Серія: Педагогіка, 229-234. 


\title{
ПСИХОЛОГІЧНІ КОМПОНЕНТИ СТРУКТУРИ МЕТОДИЧНОЇ КОМПЕТЕНТНОСТІ ВИКЛАДАЧА УСНОГО ПЕРЕКЛАДУ
}

\begin{abstract}
Пасічник Тетяна Дмитрівна
кандидат педагогічних наук, доцент, доцент кафедри англійської мови факультету перекладознавства, Київський національний лінгвістичний університет УKPAÏHA
\end{abstract}

Питання підготовки викладачів перекладу у закладах вищої освіти України $€$ недостатньо вивченим, хоча його актуальність $€$ безумовною, зважаючи на зростаючу роль перекладачів у сучасному світі.

До структури методичної компетентності викладача усного перекладу ми включаємо як методичні знання, навички, вміння та здатності, що складають когнітивно-діяльнісний компонент, так і психологічні якості, які відносимо до мотиваційно-вольового, ресрлексивно-оцінювального та соціально-комунікативного компонентів. Мотиваційно-вольовий компонент включає позитивне ставлення викладача усного перекладу до своєї роботи, зацікавленість у викладанні та задоволення від роботи, сформованість пізнавальних мотивів, бажання займатися самоосвітою та саморозвитком, прагнення досягати професійних цілей, наполегливість, здатність зосереджуватися на виконанні методичних завдань, здатність до ціннісного засвоєння знань, самовдосконалення та самореалізації у професійній діяльності, наявність інтересу і бажання вирішувати методичні завдання та ін. Рефрлексивно-оцінювальний компонент характеризується здатністю здійснювати самоаналіз своєї професійної діяльності, а також свого відношення до неї, здатністю об'єктивно та критично оцінювати результати власної методичної діяльності та регулювати ії, здатністю викладача адекватно оцінювати рівень розвитку своєї методичної компетентності, переосмислювати способи досягнення цілей навчання, визначати шляхи покращення своєї роботи, передбачати та планувати стратегію діяльності 3 урахуванням конкретної ситуації та методичного завдання, вибирати альтернативні способи вирішення методичних завдань тощо. Соціальнокомунікативний компонент структури методичної компетентності викладача усного перекладу передбачає наявність у викладача організаційних i комунікативних здібностей, здатності вибудовувати стратегії взаємодії зі студентами, обирати способи спілкування, розуміти особливості, інтереси та потреби майбутніх перекладачів, реалізовувати методичні цілі шляхом створення партнерських стосунків зі студентами та іншими викладачами, здатності викладача ефективно організовувати спілкування та обмін інформацією, здатності адекватно сприймати та передавати інформацію, а також своє відношення до неї, вмінь відстоювати свою точку зору, переконувати, поважаючи при цьому позиції та цінності інших учасників спілкування, розвивати у студентів пізнавальні здібності, професійноособистісні вміння та якості, необхідні для усного перекладача, виховувати у студентів повагу до своєї професії тощо. Усі психологічні якості, вміння та 
здатності викладача усного перекладу фрормуються у процесі його становлення як фахівця впродовж навчально-пізнавальної та професійної діяльності.

\title{
Список використаних джерел:
}

1. Черноватий, Л.М. (2013). Методика викладання перекладу як спеціальності: підручник для вищих закладів освіти за спец. Переклад. Вінниця: Нова Книга.

2. The EMT Translator Trainer Profile (2013). Competence framework. Retrieved from https://europa.eu/dgs/translation/programmes/emt/key_documents/translator_trainer_profile_en. pdf

\section{РЕЙТИНГОВА СИСТЕМА ОЦІНЮВАННЯ УСПІШНОСТІ СТУДЕНТІВ 3 ІНОЗЕМНОÏ МОВИ}

\author{
Леонова Олена Миколаївна \\ Національний технічний університет України \\ «Київський політехнічний інститут імені Ігоря Сікорського»
}

УКРÄ̈HA

Система освіти в сучасному економічному світі повинна постійно змінюватись. По-перше, зміни необхідні для того, щоб готувати високоякісних спеціалістів в певній сфері та для конкурентоспроможності в цілому. По-друге, система освіти України повинна реагувати на світові тенденції та зміни. На сьогоднішній день відбувається доволі багато істотних реформ, котрі охоплюють як шкільну освіту, так і вищу професійну.

Будь-які зміни (реформи в нашому випадку) потребують певного часу для розробки, апробації, зміни та впровадження. І після цього необхідний певний час для того, щоб ці реформи не просто почали працювати, а давати певні (бажано позитивні результати).

Введення рейтингової системи оцінювання успішності студентів було однією з таких змін. Старше покоління скоріш за все розгубиться в сучасних оцінках учнів та студентів, оскільки знання школярів оцінюються за дванадцятибальною шкалою, а студентів по стобальній системі.

3 одного боку, звісно, і студентам, і викладачам треба перевчатись та адаптуватись до даної РСО, але з іншого боку вона дає більше можливостей якомога повно та досконало оцінити знання студентів.

РCO в вищих навчальних закладах впроваджувалось одночасно 3 модульною системою викладання дисциплін, що дало додаткові можливості викладачу оцінювати успішність студентів з певного предмету або дисципліни. Отже, що собою представляє рейтингова система оцінювання успішності студентів з іноземної мови? На кредитний модуль «іноземна мова» (на різних курсах ця дисципліна, як і модуль, називається по різному) виділяється сто балів, котрі студент, виконуючи всі завдання, може заробити. Потім зароблена кількість балів трансформується в оцінку: 95-100 балів - відмінно, 85-94 - дуже 
добре, 75-84 - дуже добре, 65-74 - задовільно, 60-64 - достатньо, менше 60, але не менше 30 - незадовільно, менше 30 - не допущено.

3 вищесказаного зрозуміло, що для здачі заліку або екзамену студент повинен набрати щонайменше 60 балів. Але в сьогоднішньому світі, де міжнародні зв'язки України набирають все більшої сили (економіка, дипломатичні зв'язки, наукова та дослідницька співпраця, міжнародні конференції та публікація наукових статей в міжнародних та закордонних журналах і т.д.), тому і знання іноземної мови студентам будь-якої спеціальності надзвичайно важливі та необхідні.

Що саме повинні виконати студенти протягом навчального року, щоб заробити свої бали? Останнім часом з РСО видалили штрафні бали за відсутність на занятті без поважної причини (в цьому питанні студентам надається значна свобода - якщо вони пропускають заняття (мова йде про іноземну мову), то вони маю право та можливість відпрацювати та опанувати матеріал дистанційно: за допомогою дистанційних курсів, або окремо розроблених дистанційних завдань, поставити викладачу питання он-лайн за допомогою будь-яких зручних для обох учасників діалогу соціальних мереж або месенджерів, опрацювати матеріал та переслати його електронною поштою, створити презентацію, написати твір, есе, статтю і т.д.

Основна частина балів виділяється на основний матеріал практичних занять. 80 балів зі 100 студенти можуть отримати за практичні завдання виконання домашніх завдань, робота на парі, виконання самостійної роботи студентів (СРС). В залежності від кредитного модулю та кількості практичних занять - студенти отримують максимально 2,5 або 5 балів за кожне заняття (це залежить від кредитного модуля та кількості годин практичних занять). Далі 20 балів студенти можуть набрати завдяки написанню модульної контрольної роботи, підсумкового тесту, презентації теми зі спеціальності, захисту ресрерату і т.д.

\section{РОЛЬ ЕМОЦІЙНОГО ІНТЕЛЕКТУ У ПРОФЕСІЙНІЙ ДІЯЛЬНОСТІ ФІЗИЧНОГО ТЕРАПЕВТА}

ORCID ID: 0000-0002-4347-8907

Волошко Лариса Борисівна

канд. пед. наук, доцент, в.о. завідувача кафедри фізичної терапії та ерготерапії Полтавський національний технічний університет імені Юрія Кондратюка УКРАÏHA

Актуальність дослідження. В останні роки розвитку набув емоційний менеджмент. Для того, щоб забезпечити злагоджену роботу фрізичного терапевта у складі міждисциплінарної команди, спеціалісту необхідно вміти управляти власними емоціями, оскільки «хелперський» тип професії передбачає постійні контакти з хворими людьми, які потребують реабілітаційного вручання [1], що часто спричиняє синдром емоційного вигорання. 
Матеріали та методи дослідження. Дослідження базується на теоретичному аналізі даних літератури.

Результати дослідження. Проблеми емоційного інтелекту є порівняно новими у сучасній науці, їх розглядало обмежене коло науковців, зокрема I. Андрєєва, Н. Курмишева, Г. Пальм, А. Савенков та ін. Відомо, що різні види праці несуть неоднакову емоційну складову, тому можемо виділити наступні види праці: емоційна, частково емоційна, неемоційна. Емоційну працю характеризують як безпосередньо суб'єкт-суб'єктну взаємодію «обличчям до обличчя» у ході щоденних професійних дій. Зокрема, професійна діяльність фізичного терапевта $є$ яскравим прикладом емоційної праці, 3 великим ризиком емоційного вигорання.

Термін «емоційна праця» був введений А. Хохшільдом у книзі «Керована душа : комерціалізація людського почуття» в 1983 р. Автор стверджує, що така робота підпорядковується «почуттю правил» (управлінню власними емоціями у відповідності до умов певної соціальної ситуації) та насправді означає комерціалізацію почуттів [2]. Неемоційна праця - це праця, у ході якої працівнику не доводиться контактувати з клієнтами, отже, такий вид професій не відноситься до соціономічних. Від осіб неемоційної праці не потрібні фальшиві емоції на догоду клієнтові. Частково емоційний праця - $є$ проміжним варіантом між емоційним і неемоційним видами праці. Однак, на нашу думку, такий поділ видів праці є умовним, оскільки ніхто не застрахований від негативних наслідків, пов'язаних з роботою. Співробітники емоційно й частково емоційної праці схильні до стресу, співробітники неемоційної праці - до стану монотонії (нудьги), і ніхто з них не застрахований від синдрому емоційного вигорання.

У 1991 році психологами П. Селовеєм та Дж. Майєром було введено поняття емоційного інтелекту (англ. EQ). Американський психолог Д. Гоулмен на матеріалах психологічних та соціологічних досліджень довів, що успіх у житті залежить не тільки від логічного інтелекту (IQ), але й від емоційного $\mathrm{EQ}$. Науковці виділили два підтипи емоційного інтелекту: міжособистісний та внутрішньоособистісний. Емоційний інтелект забезпечується самоконтролем та полягає в умінні дозувати емоції. Він проявляється у сфері спілкування і відбиває внутрішній світ особистості, його зв'язки з поведінкою в реальному житті [2].

Цікавим є дослідження щодо можливості впливу на емоційний інтелект. $€$. Файнберг [3] вказує на таку залежність: чим вищий рівень освіти та доходи, ти більш високий EQ. Ми вважаємо, що спеціаліст може розпочати професійне життя з високим рівнем емоційного інтелекту, але з часом він може знизитися, якщо особистість набуває досвіду негативних емоційних реакцій внаслідок дії хронічних стресорів, або в умовах, де ії ображають чи зневажають.

Внаслідок тривалого впливу професійних стресів середньої інтенсивності розвивається синдром емоційного вигорання (CEB) - захисна реакція організму, процес поступової втрати емоційної, когнітивної та фрізичної енергії, що виявляється в симптомах емоційного, розумового виснаження, фізичного стомлення, особистої відстороненості і зниження задоволення виконанням роботи. Виділяють три ключові ознаки СЕВ. Розвитку СЕВ передує період підвищеної активності, коли людина повністю занурена в роботу, забуває про 
70 • Problèmes et perspectives d'introduction de la recherche scientifique innovante $\bullet$ Volume 5

власні потреби, а потім настає перша ознака - виснаження - почуття перенапруги та вичерпання емоційних і фізичних ресурсів, що не проходить після нічного сну.

Іншою ознакою CEB $є$ особистісна відстороненість - фахівця майже ніщо не хвилює у професійній діяльності, ніякі обставини не викликають емоційного відгуку, що неприпустимо для фрізичного терапевта. Третьою ознакою $є$ відчуття втрати ефективності, тобто відсутність бачення власних перспектив у професійній діяльності, зниження задоволення роботою, втрата впевненості у свої професійні можливості.

Висновки. 1. Емоційний інтелект володіє ще до кінця не вивченим потужним стресозахисним та прогностичним потенціалом, його якісна відмінність від відомих стратегій подолання стресу полягає в умінні не лише ефективно долати та адаптуватися до емоційногенних ситуацій, а й попереджати їх на когнітивному рівні. 2. Для фізичних терапевтів, як представників соціономічної професії, необхідно зосередитися над виробленням певного «емоційного імунітету», формуванням уміння надситуативного реагування на складні стресогенні ситуації професійної діяльності у галузі охорони здоров'я.

\section{Список використаних джерел:}

1. Волошко, Л.Б. (2006). Формування професійної компетентності майбутніх фрахівців з фізичної реабілітації у процесі вивчення медико-біологічних дисциплін (дис. ...канд. пед. наук). Київ.

2. Гоулман, Д. (2009). Эмоциональный интеллект. М.: АСТ Москва; Владимир: ВКТ, 2009.

3. Файнберг, Е. (2007). Эмоциональный интеллект: владеть страстями выгоднее, чем умом. Вилучено з https://psyfactor.org/news/eq.htm

\section{РОЛЬ ПЕДАГОГА В ПРОЦЕССЕ ОСУЩЕСТВЛЕНИЯ SCRUM ТЕХНОЛОГИИ}

Бобр Арина Дмитриевна

студентка I курса магистратуры фракультета иностранных языков ГОУ ВО МО «Государственный социально-гуманитарный университет»

Мигдаль Ирина Юрьевна

канд. филол. наук, доцент кафедры германо-романских языков и методики их преподавания факультета иностранных языков ГОУ ВО МО «Государственный социально-гуманитарный университет» РОССИЙСКАЯ ФЕДЕРАЦИЯ

В течение последней декады процесс обучения всё больше подвергается различным модификациям из-за повышающегося количества требований к системе подготовки достойных кадров для рынка труда. Считается неэфффективным традиционное обучение, в рамках которого педагог носитель всей необходимой информации, который передаёт знания «из уст в уста». Сегодня роль преподавателя и его деятельность в аудитории 
пересматривается; тенденция такова, что теперь педагог выступает помощником, советчиком в добыче знаний и достижении целей. С появлением большего количества ресурсов, где можно найти всю необходимую информацию, одного учебного пособия недостаточно для сдачи государственного экзамена или приобретения полезного знания, которое будет использовано обучающимся и после окончания образовательного учреждения.

В системе образования происходят коренные изменения, которые выражаются в появлении и становлении различных инновационных технологий, способствующих улучшению качества обучения и оптимизации трудозатрат самого преподавателя. На данный момент одной из самых популярных методик является eduScrum, название которого сложилось из английских слов «education» и «Scrum». Данная образовательная технология уже успела себя зарекомендовать как эффективная, простая в применении система, в которой обучающиеся выступают как добытчики знаний, самостоятельно работающие в группах. Изначально была разработана методология Scrum для сфреры бизнеса и IT, где появилась нужда в реорганизации работы над крупными проектами. Целью данной технологии было установление системного подхода к выполнению задач по принципу командной работы и полной автоматизации работников.

Модель Scrum была разработана Дж. Сазерлендом и К. Швабером в конце $\mathrm{XX}$ века и представляла собой работу укомплектованных специалистами команд в течение спринтов - отрезков времени, за которые выполняются намеченные задачи проекта. Данная технология привлекает внимание благодаря положительным отзывам и репутации, которую она успела заполучить в американских, японских, а затем уже и в российских компаниях. Однако в образование её внедрила группа учителей из Голландии во главе с Вилли Вейнандсом - преподавателем химии, который вдохновился работами Сазерленда о Scrum. По его словам, Вейнандс был недостаточно удовлетворён результатами практических работ своих подопечных, что привело его к поиску новых приёмов в обучении [2].

В результате в 2011 году eduScrum появился на свет как образовательная технология, переложившая принципы и основные элементы Scrum на реалии сферы образования. С недавних пор она применяется и во многих школах России в программах различных предметов: от русского языка до информатики. Данная методика имеет ряд положений, согласно которым и осуществляется её внедрение на уроках.

1. eduScrum основывается на командной работе, следовательно, первым шагом в его внедрении является распределение обучающихся в рабочие группы. Однако, важным дополнением выступает тот факт, что обучающиеся должны выбирать команду, основываясь на практических навыках товарища, а не на принципе дружбы.

2. Обязателен Scrum-мастер каждой группы для устранения препятствий слаженной работе и подбадривания членов команды. Их выбирает сам педагог (или обучающиеся). Scrum-мастер имеет право набрать команду на этапе организации работы.

3. После объяснения правил данной технологии аудитории и пояснения вида конечного продукта деятельности необходимо проработать задачи и 
разделить их между командами (в зависимости от типа проекта или учебной работы, которая была выбрана).

4. Устанавливается протяжённость спринта - отрезка времени, за который команды осуществляют рабочую деятельность. Важное дополнение: в течение спринта нельзя убирать или добавлять новые задачи для решения, поскольку это повлияет на общий лад работы и ретроспекцию.

5. В начале и конце каждого урока в рамках eduScrum проходят stand-up собрания, на которых обучающиеся выясняют, что было сделано вчера для достижения цели, что будет делаться сегодня и какие препятствия образуются.

6. Каждой командой ведутся Scrum-доски (плакаты, онлайн-версии и т.п.), на которых обучающиеся отмечают задачи, находящиеся в разработке, сделанные задачи и те, которые предстоит осуществить в заданном спринте.

7. В конце каждого спринта осуществляется ретроспекция, т.е. анализ командной работы, определение посильности выбранных задач на данный отрезок времени, отчёт перед преподавателем о проделанной работе.

Система применения eduScrum достаточно подробно прописана Сазерлендом и командой Вейнандса, однако при ближайшем рассмотрении встаёт вполне очевидный вопрос: что всё это время делает педагог? Известно, что обучающиеся работают в тщательно отобранных командах, добывают знания самостоятельно и успешно справляются с задачами без помощи учителя. Есть ли место в Scrum педагогу?

Проблема, поставленная анализом данной педагогической технологии, представляет собой слабое место в методике, поскольку сам eduScrum является инновацией. Для её решения необходимо обратиться к первоисточнику - создателю всей методологии Scrum - Джеффу Сазерленду. В своих трудах он обращает внимание на деятельность руководителя во время внедрения технологии в ІТ-корпорациях для устранения неполадок в работе над важным проектом. Согласно Сазерленду, двумя необходимыми факторами для слаженных действий команды являются понимание общей цели и полная автономность группы, что выражается в отсутствии прямого контроля заказчика или генерального директора компании. [1] Команда самостоятельно выбирает индивидуальный темп работы в соответствии с задачами, выделенными на спринт.

Однако, в условиях абсолютной автономности любой контролёр не важен; его присутствие или же отсутствие никаким образом не влияет на команды. Так кажется только с первого взгляда, если воспринимать руководствующее звено в качестве лица, только осуществляющего различные проверки и вмешивающегося в работу Scrum-групп. И здесь, по словам Дж. Сазерленда, процветают лишь те руководители, которые осознают изменение своей роли в процессе осуществления Scrum. Он соглашается с тем, что многим приходится нелегко, отказываясь от привычного контроля подчинённых и вмешательства в их ежедневную деятельность. Но, следуя правилу осознания общей цели, руководитель способен привести своих коллег к небывалым успехам и высокому уровню эффективности.

Также, роль лидера в данной концепции заключается в том, чтобы минимизировать вторжение извне, обеспечить комфортные условия работы для Scrum-команд и быть в доступности для своих подчинённых. Все вышеперечисленные элементы характеризуют прогрессивного руководителя, 
осознающего важность не своей личности, а проекта, и уважающего своих коллег.

В материалах, описанных и разработанных Сазерлендом и Вейнандсом, можно найти опорные сигналы для решения проблемы о роли педагога в рамках преподавания по Scrum. Перенося концепцию руководителя на образовательный процесс, становится ясно, что лидером компании здесь выступает сам учитель. Преподаватель здесь и заказчик проекта, и лидер подготовительной кампании, и регулятор действий и непредвиденных ситуаций. Суммируя примеры деятельности руководителя и перекладывая Scrum на реалии общеобразовательных учреждений, можно выделить некоторые закономерности для следования в осуществлении eduScrum в школе:

1. В первую очередь педагог - организатор деятельности. Именно он объясняет принципы Scrum, помогает в формировании команд и задаёт параметры проекта.

2. Педагог - регулятор деятельности. Он определяет сроки сдачи и продолжительность спринтов, обеспечивает слаженную работу учеников, регулируя влияния извне (соответствие календарно-тематическому плану, наличие олимпиад и ВПР, участие в конкурсах и т.д.).

3. Также педагог - консультант. Во время прохождения спринтов он открыт для обсуждения различных деталей и проблем обучающихся, подсказывает выход из тупиковых ситуаций и указывает на дополнительные ресурсы поиска.

4. Педагог - лектор. В некоторых ситуациях при рассмотрении особенно сложных тем учитель может выступать в качестве лектора, т.е. объяснить материал самостоятельно, однако важно не злоупотреблять данной формой работы.

5. Необходимо помнить, что в Scrum педагог также и контролёр, поскольку он и есть заказчик проекта. В его обязанности входит оценка конечного продукта и личного вклада каждого обучающегося, разбор недостатков работы команд и постоянное наблюдение.

Таким образом, роль преподавателя в рамках осуществления eduScrum меняется и становится многокомпонентной. Среди перечисленных закономерностей для педагога невозможно выбрать одну и действовать согласно данной модели. Каждый учитель в праве самостоятельно выбирать процентную составляющую своей роли в образовательной технологии в зависимости от сложности проекта, календарно-тематического плана, длительности спринтов и т.п. Педагог здесь не может быть ограничен, поскольку eduScrum в первую очередь - это творческая деятельность и совместная работа учителя и ученика.

\section{Список используемых источников:}

1. Сазерленд, Джефф. (2019). Scrum. Революционный метод управления проектами (4-е изд.). Москва: Манн, Иванов и Фербер.

2. Delhij, A., van Solingenand, R., Wijnands, W. (2015). The eduScrum Guide. http://eduscrum.nl/en/file/CKFiles/The_eduScrum_Guide_EN_1.2.pdf. 


\section{СУЧАСНІ ІНФОРМАЦІЙНІ ТЕХНОЛОГІЇ У ПРОФЕСІЙНІЙ ПІДГОТОВЦІ МАЙБУТНІХ ПЕДАГОГІВ}

\section{Литвин Андрій Феодорович}

кандидат педагогічних наук, доцент кафедри теорії

та методики професійної підготовки

ДВНЗ «Переяслав-Хмельницький державний педагогічний

університет імені Григорія Сковороди»

УКРӒ̈HA

Внаслідок інформатизації суспільства змінюється структура та зміст педагогічної освіти. В сучасних умовах невідкладною потребою вищої педагогічної освіти є підготовка випускника педагогічного навчального закладу до професійної діяльності в інформаційному суспільстві. У зв'язку зі зміною ролі інформації в суспільстві необхідно сфрормувати інформаційну компетентність майбутнього педагога. За таких умов забезпечення спрямованості освіти на професійний та особистісний розвиток майбутніх педагогів потребує оптимального використання нових інформаційних технологій.

Інформатизація освіти - це не лише зміна технічної озброєності педагогічної праці, це зміна всього комплексу поглядів і підходів педагога, його готовності передавати свої знання і досвід. Це формування педагогічної культури нового типу, яка потребує оновлення змісту освіти, підходів і методів, організаційних фрорм професійної підготовки. Інформатизація діяльності педагога передбачає використання в навчально-виховному процесі інноваційних засобів навчання, зокрема комп'ютерної та телекомунікаційної техніки, з метою раціонального й інтенсивного процесу формування знань, умінь і навичок, передачі, комутації та переробки навчально-методичної інформації [1].

Проблемам професійної підготовки педагога в сучасних умовах присвячені дослідження багатьох фрілософрів та педагогів (В. Андрущенко, С. Гончаренко, Р. Гуревич, І. Зязюн, В. Кремень, О. Пєхота, Л. Пуховська та С. Сисоєва та ін. ін.), психологів (Г. Балл, І. Бех, О. Кульчицька, Л. Мітіна, В. Моляко, В. Семиченко та ін.).

Особливості підготовки майбутніх педагогів різних спеціальностей до використання нових інформаційних технологій у навчальному процесі розглядають (М. Жалдак, О. Комар, В. Кондратова, Г. Кручиніна, Е. Разинкін, М. Левшин, Д. Мазоха, О. Шиман, В. Фрадкін та ін.)

Впровадження інформаційних технологій навчання у практику професійної підготовки педагога супроводжується рядом проблем. Це й недостатня мотиваційна готовність викладацького складу, яка спричинена недостатньою сформованістю інформаційної культури, неготовністю змінювати традиційну організацію навчального процесу і систему контролю за успішністю студентів, неготовністю розробляти нові навчальні елементи та їх програмний супровід.

Профресійна підготовка майбутніх педагогів із застосуванням інформаційнокомунікаційних технологій $€$ основною передумовою і перспективою для 
майбутнього.

Застосування інформаційно-комунікаційних технологій в галузі освіти і безпосередньо в діяльності майбутнього педагога стає загальною необхідністю. Впровадження інформаційно-комунікаційних технологій у навчально-виховний процес забезпечить поступовий перехід освіти на новий, якісний рівень. Інформаційно-комунікаційні технології позитивно впливають на всі компоненти системи навчання: мету, зміст, методи та організаційні форми навчання, засоби навчання, що дозволяє вирішувати складні і актуальні завдання педагогіки для забезпечення розвитку інтелектуального, творчого потенціалу, аналітичного мислення та самостійності педагогічних працівників. Для ефективної модернізації освіти та оновлення технічного арсеналу засобів навчання необхідно оптимізувати реалізацію державних програм, спрямованих на інформатизацію, комп'ютеризацію та оновлення матеріальнотехнічної бази шкіл, надання всім вільного доступу до мережі Інтернет. [2]

Основною метою впровадження сучасних інформаційних технологій в навчання $\epsilon$ сприяння різнобічному розвитку особистості, підвищення продуктивності праці, наповнення її творчим змістом. Впровадження сучасних інформаційних технологій у професійну підготовку майбутніх педагогів потребує поєднання всебічного розвитку особистості, наповнення професійної підготовки індивідуальним змістом, врахування інтегративного підходу та специфіки майбутньої професії.

Висновок. Отож, формування готовності майбутнього педагога до інноваційної діяльності в інформаційному освітньому просторі $\epsilon$ актуальною проблемою сучасності. Оскільки, сучасне інформатизоване та високотехнологічне суспільство потребує фрахівця, який є не тільки різнобічно розвиненою особистістю, але й спеціалістом, здатним швидко адаптуватися до освітніх інновацій, що привносяться інформаційно-комунікаційними технологіями, спроможним ефективно розв'язувати професійні завдання за допомогою новітніх технологій, здібним до самостійного перенавчання, самостійного удосконалення власної підготовки. Зумовлюється потреба у підвищенні ефективності формування готовності майбутніх педагогів до практичної діяльності шляхом використання сучасних інформаційних технологій у навчально-виховному процесі.

\section{Список використаних джерел:}

1. Гуржій, А., Волинський, В. \& Коцур, В. (2003). Інформатизація освіти і проблеми створення комп'ютерних програмнопедагогічних засобів навчання. Освіта України, (23), 9- 10.

2. Bestreferat. Вилучено з http://www. bestreferat. ru/reat-213190. html 


\section{ТРЕНІНГ ДЛЯ СТАРШИХ ПІДЛІТКІВ-ВИХОВАНЦІВ ШКІЛ-IHTЕРНАТІВ}

ORCID ID: 0000-0001-8595-1961

Єрьоміна Лілія Євгенівна

Мелітопольський державний педагогічний університет імені Богдана Хмельницького

УКРАЇ̈А

Профрілактика вживання наркотичних речовин у сучасному суспільстві набуває особливого значення, адже у період культурної та соціальноекономічної кризи найбільш вразливими до соціально-негативних явищ $є$ підлітки, які виховуються поза межами сімейного оточення. Теми 3 попередження наркоманії серед дітей є окремим напрямом профілактичної роботи соціального педагога в школі-інтернаті. У науково-педагогічному досвіді є чимало робіт, автори яких висвітлюють можливі форми та методи профілактики наркоманії в закладах освіти, наприклад, С. Архипова, В. Афранасьєва, І. Звєрєва, А. Капська, Г. Майборода, О. Удалова, С. Шишкунов, І. Шишова та ін.). Мета даної публікації полягає у висвітленні теми тренінгу, його структурних елементів та отриманих результатів після його впровадження у соціально-виховний процес школи-інтернату. Наведемо опис проведеного нами тренінгу. Тема: «Наркотики як загроза світового масштабу». Мета: розширити рівень поінформованості підлітків з проблем, пов'язаних із вживанням наркотиків, з'ясувати найбільш поширені причини їхнього вживання підлітками, вплив на організм і соціальні наслідки згубної пристрасті; сформувати прагнення протидіяти вживанню наркотичних речовин, займати активну життєву позицію. У ході проведення тренінгу ми мали розв'язати наступні завдання: діагностувати рівень знань вихованців щодо означеної проблеми; надати інформації учасникам про причини і наслідки уживання наркотиків, їх впливу на загальний розвиток людини; сформувати навички оцінювання ситуації ризику та сприяти усвідомленню вихованцями потреби у відповідальності за власні рішення; перевірити рівень засвоєння інформації. Відповідно структури тренінгу нами запропоновано такі складові: вступ (ознайомлення з темою та метою зустрічі, прийняття правил); оцінка рівня інформованості, актуалізація проблеми, інформаційний блок (мозковий штурм «Нароктики: без «за», «тільки проти»?»; інформаційне повідомлення «Статистика України»; вправа «Початок і фрінал»; вправа «Шприц як засіб допомоги - кому і навіщо?»; вправа «Веселка замість шквалу»; завершення роботи, перевірка рівня засвоєння інформації («Конгрес у школі-інтернаті»; вправа «Стежина чи широкий шлях»). 3 метою оцінки ефективності проведення тренінгу ми запропонували учасникам (учням Новомиколаївської школи- інтернату Запорізької області) перед початком тренінгу відповісти на запитання анкети «Знаю і не знаю». Так, наприклад, з 19 учасників рівень обізнаності з проблеми вживання наркотичних засобів розподілився наступним чином: низький рівень 13 учнів (68\%), середній рівень - 6 учнів (32\%), високого рівня не було виявлено. І, відповідно, по завершенні тренінгу учасник відповідали на ті ж запитання. Порівнюючи відповіді, було виявлено певні 
зміни: низький рівень 9 учнів (47\%), середній рівень - 10 учнів (53\%), високого рівня не було виявлено. Отже, ефективність даної роботи підтверджено, завдання - розв'язано та мету - досягнуто. Перспективу подальших досліджень вбачаємо у розробленні комплексу тренінгових вправ, що сприятимуть більш якісній організації профілактичної діяльності з підлітками в закладах освіти.

\title{
Список використаних джерел:
}

1. Капська, А. Й., Карпенко, О. Г., Лук'янова, Н. Л. \& Підлісна, Н. Б. (2001). Деякі аспекти профрілактики тютюнопаління серед школярів: методичні рекомендації для шкільних психологів та класних керівників. Київ: Європринт,.

2. Федорченко, Т. Є. (2003). Кроки до здоров'я (Профрілактика вживання неповнолітніми наркотичних речовин).

3. Сприяння просвітницькій роботі «Рівний-рівному» серед молоді України щодо здорового способу життя». (Програма).

DOI 10.36074/29.11.2019.v5.08

\section{УДОСКОНАЛЕННЯ ТЕХНІКО-ТАКТИЧНОЇ ПІДГОТОВКИ БОРЦІВ ВІЛЬНОГО СТИЛЮ НА ЕТАПІ ПІДГОТОВКИ ДО ВИЩИХ ДОСЯГНЕНЬ}

\begin{abstract}
Первачук Олег Ігорович
викладач циклової комісії «Гуманітарної та соціально-економічної підготовки» Відокремлений структурний підрозділ - Коледж телекомунікацій та комп'ютерних технологій Національного університету «Львівська політехніка»

Первачук Ростислав Вікторович викладач каферди «Атлетичних видів спорту» Львівський державний університет фрізичної культури УКРӒ̈̈А
\end{abstract}

Методика початкової техніко-тактичної підготовки борців повинна вдосконалюватися на основі дослідження змагальної діяльності та майстерності провідних спортсменів, тобто з дотриманням первинності змагань і вторинності тренувального процесу.

В останні роки у вільній боротьбі, відповідно внесеним змінам до правил 2013 і 2018 років, відбуваються істотні зміни в змісті змагального поєдинку, регламенті змагань, змінились уявлення про методику підготовки висококваліфікованих спортсменів. Так, в сучасній боротьбі скоротився час сутички, процес єдиноборства став проходити активніше й агресивніше. Це вимагає від борців якнайшвидшого вирішення техніко-тактичних завдань i застосування ефрективних атакуючих комбінаційних дій. Разом 3 тим, спостерігаються і негативні тенденції: звуження змагального технічного арсеналу і збіднення тактики поєдинків [1]. Крім того, на думку провідних фахівців: Є.В. Ручки, Ананченка К. В., Айсуєва Л.Д. та багатьох інших, існуюча 
методика навчання все ще недостатньо враховує вимоги сучасної боротьби, що негативно позначається на зростанні спортивної майстерності борців і визначає актуальність даного дослідження [2;3].

Проведений аналіз літератури показав, що тактика ведення поєдинку $є$ недостатньо вивченим розділом тактичної підготовки спортивної боротьби, внаслідок чого тактика ведення поєдинку залишається слабкою ланкою в системі підготовки борців вільного стилю. Отже, існує необхідність внесення коректив у методику технічної i тактичної підготовки кваліфікованих спортсменів-борців вільного стилю і розробки відповідної програми.

Для розробки ефективної діючої програми удосконалення техніко-тактичної підготовки борців вільного стилю, необхідно в перші чергу чітко окреслити її основні мету і завдання.

Основною метою пропонованої програми $\epsilon$ удосконалення технікотактичної підготовки борців вільного стилю на основі загальнодидактичних принципів і принципів спортивного тренування з використанням приватних методик навчання і врахуванням сучасних вимог змагальної діяльності.

Основним завданням програми $є$ вдосконалення професійних вмінь та навиків кваліфрікованих борців вільного стилю на етапі підготовки їх до вищих досягнень.

Програма розроблена за методикою програмованого навчання, що передбачає поділ матеріалу на окремі частини, реалізацію в кожній з них конкретних завдань і використання методів контролю його засвоєння. Технікотактична підготовка згідно розробленої програми здійснюється на основі загальнодидактичних принципів і принципів спортивного тренування 3 використанням приватних методик навчання.

Тренувальний процес включає дві складові:

- навчання техніці боротьби;

- цілеспрямоване вдосконалення техніки боротьби.

Для навчання та вдосконалення техніки боротьби використовуються такі групи методів тренування:

- без противника (на перших етапах навчання);

- з умовним противником (допоміжними пристосуваннями - манекенами і т.д.);

- з партнером (які допомагають і створює вигідні ситуації); з противником (протидіє напарником).

Для навчання техніці боротьби використовуються методи:

- цілісний;

- розчленований (по частинах);

- розучування за допомогою вправ, що підводять;

- ігровий метод.

Для цілеспрямованого вдосконалення техніки боротьби використовуються методи:

- розчленований (по частинах);

- розчленовано-конструктивний (комбінований) метод;

- моделювання (формальне моделювання, ігрове протиборство за певними правилами, ффункціональне моделювання епізодів і ситуацій змагального протиборства).

Методом цілісної вправи проводиться навчання досить простим прийомам, розчленованим методом - складнішим в координаційному відношенні прийомам. Метод цілісної вправи є найбільш ефективним, так як він дозволяє 
формувати руховий навик з використанням різних методичних прийомів. Метод розучування за допомогою вправ, що підводять, полягає в послідовному виконанні вправ, що призводить до оптимального виконання самого розучуваного руху, що значно підвищує швидкість його засвоєння.

На всіх етапах виконання програми необхідно забезпечити високий рівень мотивації, індивідуальний підхід, розвиток фізичних і вольових якостей, необхідних для ефективного виконання прийомів.

При методі моделювання модельні характеристики кращих спортсменів служать орієнтиром у побудові навчально-тренувального процесу, в тому числі в проведенні тренувальних, контрольних та відбіркових сутичок. Вони також дають інформацію для побудови раціональної тактики поєдинків з ймовірними суперниками в майбутніх змаганнях. Для цього в тренуванні моделюються різноманітні ситуації, які можуть скластися в сутичках з ними. При цьому основою для моделювання тренувальних завдань можуть бути класифікація елементів техніки і тактики спортивної боротьби, а також результати аналізу змагальної діяльності найсильніших борців.

Структура програми удосконалення техніко-тактичної підготовки борців вільного стилю показана на рис.1:

\begin{tabular}{|c|c|}
\hline Дні тижня & Вид занять \\
\hline Понеділок & $\begin{array}{l}\text { Елементи рекреації (15хв) } \\
\text { Основне тренування (1,5год.) } \\
\text { Елементи техніко-тактичного аналізу } \\
\text { Ігрові елементи }(0,5 \text { год.) } \\
\text { Елементи рекреації }(15 \mathrm{xв})\end{array}$ \\
\hline Вівторок & $\begin{array}{l}\text { Елементи індивідуальної та самостійної роботи (за складеною в } \\
\text { залежності від особливостей іх фізнчного стану інднвідуальною } \\
\text { програмою) }\end{array}$ \\
\hline Середа & $\begin{array}{l}\text { Елементи рекреації (15хв) } \\
\text { Варіатнвна складова тренування(45хв) } \\
\text { Основне тренування }(1,5 \text { год.) } \\
\text { Елементи техніко-тактичного аналізу } \\
\text { Варіативна складова тренування }(0,5 \text { год.) } \\
\text { Елементи рекреації (15хв) }\end{array}$ \\
\hline Четвер & $\begin{array}{l}\text { Елементи індивідуальної та самостійної роботи (за складеною в } \\
\text { залежності від особливостей ї фізнчного стану інднвідуальною } \\
\text { програмою) }\end{array}$ \\
\hline П'ятнищя & $\begin{array}{l}\text { Елементи рекреації (15хв) } \\
\text { Основне тренування }(1,5 \text { год.) } \\
\text { Елементи техніко-тактичного аналізу } \\
\text { Варіатнвна складова тренування }(0,5 \text { год.) } \\
\text { Елементи рекреаціі }(15 \mathrm{xв})\end{array}$ \\
\hline Субота & \multirow{2}{*}{$\begin{array}{l}\text { Вихідні дні } \\
\text { Елементи рекреації } \\
\text { (за бажанням) }\end{array}$} \\
\hline Неділя & \\
\hline
\end{tabular}

Рис. 1. Структура програми удосконалення техніко-тактичної підготовки борців вільного стилю 
Структура програми удосконалення техніко-тактичної підготовки борців вільного стилю включає в себе наступні елементи:

- Основне тренування.

- Варіативна складова тренування (являє собою змінну складову, яку обирає тренер у відповідності до виникаючої потреби розширення програми основного тренування).

- Елементи техніко-тактичного аналізу (Предметом якого можуть бути: ефрективні техніко-тактичні дії, що становлять арсенал провідних борців світу; тактика ведення поєдинку; особливості сучасної практики суддівства на відповідальних міжнародних змаганнях зі спортивної боротьби, корекція технічних дій).

- Ігрові елементи (виявлені і уточнені спеціалізовані гри, які відображають ситуації, що найбільш часто зустрічаються в спортивних поєдинках i цілеспрямовано впливають на техніко-тактичну підготовленість; ігрові види спорту).

- Елементи рекреації (спортивний та оздоровчо-спортивний масаж, який проводиться перед кожним тренуванням та після нього самостійно або в парах і допомагає організму впоратися з навантаженнями).

- Елементи індивідуальної та самостійної роботи (Індивідуальний підхід в навчанні забезпечує органічний взаємозв'язок між початковим навчанням i вищою спортивною майстерністю).

Дана схема дозволяє задіювати спортсменів у тренуваннях фрактично кожного дня, зміюючи характер навантажень, а також містить елементи фізичної та пасивної рекреації для відновлення сил та покращення загального самопочуття.

Основне тренування умовно можна поділити на три етапи:

1) розминка;

2) робота над вправами: вправи на засвоєння, відпрацювання, закріплення, повторення.

- матеріал на занятті розбивається на ряд завдань;

- вправи та прийоми вивчаються від простіших до складніших;

- здійснюється поточний контроль засвоєних вмінь та навиків.

3) спаринги.

Варіативна складова програми являє собою змінну складову, яку обирає тренер у відповідності до виникаючої потреби розширення програми основного тренування.

До варіативної складової розробленої програми входять:

- Крос, пробіжка на свіжому повітрі;

- Силові вправи («кубинський жим»);

- Вправи на розтяжку (стречинг).

Важливим предметом елементу аналізу $€$ корекція технічних дій 3 враховуванням ії виду, причини виникнення і індивідуальних особливостей борця, яку можна застосовувати на всіх етапах програми. Щоб усунути типові помилки при навчанні технічної дії необхідно виокремити невдалі елементи прийомів, пояснити нюанси, щоб спортсмени зрозуміли правильність необхідної техніки з біомеханічної точки зору.

Для наглядності предмету аналізу можна використовувати різні технічні засоби зі зворотним зв'язком (наприклад відеозапис поєдинків на смартфоні чи відео з мережі Internet). 
Ігрові елементи служать ефективним засобом комплексного розвитку фізичних якостей спортсменів (спритності, сили, швидкості, витривалості та ін..) під час вирішення основних рухових завдань, що особливо важливо для борців вільного стилю, яким важливо мати хорошу реакцію і вміти швидко приймати рішення в стресових ситуаціях.

В якості рекреаційних елементів я обрав спортивно-оздоровчий масаж перед тренуванням та після його закінчення. Масаж перед тренуванням допоможе розігріти м'язи і запобігти можливим травмам від неправильної підготовки м'язів до спортивних занять. Інтенсивний масаж м'язів після тренування з приділенням особливої уваги тим групам м'язів, на яких сконцентровано основне навантаження. Вид тренувального масажу і ступеня його інтенсивності підбираються безпосередньо в залежності від м'язів, на які буде націлене основне навантаження.

Згідно програми два дні в тиждень виділяються на індивідуальну роботу 3 тренером та самостійну роботу спортсменів за індивідуальною програмою тренувань, складеною тренером 3 врахуванням їх фрізіологічних та психологічних особливостей. При цьому зростає частка самостійної роботи і спортсмени займаються з урахуванням індивідуальних темпів засвоєння знань, умінь і навичок (при постійному контролі за їх діяльністю зі сторони тренера). Це дає змогу виробляти індивідуальний стиль і тактику ведення поєдинку, формувати й удосконалювати коронну техніку на основі знову освоюваних і постійно оновлюваних способів тактичної підготовки і використання сприятливих динамічних ситуацій.

Для навчання та вдосконалення техніки боротьби застосовуються найрізноманітніші контрольно-тренажерні пристрої, манекени, мішки і т.д., від наявності і якості яких залежить ефективність тренувань.

\section{Список використаних джерел:}

1. Актуальні проблеми розвитку традиційних і східних єдиноборств: Збірн. наук. праць $X$ міжн. Інтернет наук. - метод. конфр. (10). Х.: Національна академія Національної гвардії України, 2016.

2. Ручка, Є. В. (2016). Удосконалення методики підготовки юних борців вільного стилю. Науковий часопис,(15): Науково-педагогічні проблеми фізичної культури (фізична культура і спорт), (10) 104-108.

3. Ручка, Є. В. (2016). Удосконалення підготовки юних борців в умовах динамічного розвитку вільної боротьби. Траектория науки, 2(7). Вилучено 3 http://pathofscience.org/index.php/ps/article/view/71. 


\title{
ФОРМУВАННЯ ПСИХОЛОГІЧНОЇ ГОТОВНОСТІ ДІЯЛЬНОСТІ ВИКЛАДАЧА ПРИ ВИКЛАДАННІ МАТЕМАТИЧНИХ ДИСЦИПЛІН
}

\begin{abstract}
Полякова Євгенія Віталіївна
студентка МТ-Б16

Донецький національний університет імені Василя Стуса

Данильчук Оксана Миколаївна

кандидат педагогічних наук, старший викладач кафедри прикладної математики Донецький національний університет імені Василя Стуса

УКРАЇ̈А
\end{abstract}

у час соціальних трансформацій, що зумовлюють нові соціальноекономічні умови професійної діяльності, особливої ваги набувають внутрішні, психологічні ресурси особистості. Стійкість, стабільність та якість професійної діяльності обумовлюється особливостями психологічної готовності майбутнього фахівця. Чільне місце займає особистісна готовність до професійної діяльності майбутніх викладачів як фахівців, покликаних розказати і показати, що математика дійсно присутня в житті кожного.

Аналізуючи та досліджуючи, як педагогічний так і психологічні аспекти процесу викладання математики в загальноосвітніх навчальних закладах, ми побачили, що дуже важко працювати із незацікавленою дитиною. А в час сучасних технологіях зацікавлених все менше в математиці, тож потрібна неабияка психологічна підготовка майбутнього фахівця, хоча частіше за все далі після школи більшість хочуть бути програмістами, економістами, правовиками і т.д.

Тому, умови формування психологічної готовності студентів до викладання математичних дисциплін в умовах соціальних трансформацій, на наш погляд, висвітлені недостатньо. Що говорить, про актуальність проблеми та її недостатня розробленість, які і зумовили вибір теми даної статті.

Реальна практика демонструє, що найчастіше успіху в соціальній та професійній кар'єрі досягають далеко не випускники педагоги 3 дипломом 3 відзнакою, а ті з них, які виявляли активність, реалізовували себе в різних видах діяльності: громадській, культурній, комунікативній, науковій, а навчальна діяльність - лише одна з них. Можна констатувати, що оцінка якості підготовки випускника за його знаннями та вміннями, що демонструються на поточних і підсумкових іспитах, неадекватно характеризує дійсний рівень їх готовності до успішної професійної діяльності.

Знання та вміння, як зазначає Г.І. Ібрагімов, - лише мізерна частина особистісних властивостей, що впливає на успішність діяльності, спілкування, поведінки фахівця. I поки результативним критерієм якості підготовки фахівців буде успішність з предметів, керівники та викладачі, студенти і їх батьки основні зусилля традиційно будуть спрямовувати саме на цей компонент - на формування знань. Тому питання фрормування психологічної готовності до професії, на сьогодні $€$ ключовим моментом, що визначає всю спрямованість 
освітнього процесу в навчальному закладі, який здійснює професійну підготовку майбутніх фахівців.

Формування психологічної готовності студентів до навчання або готовність до змін діяльності в контексті психологічної готовності при викладанні математичних дисциплін обумовлений всією системою навчально-виховної роботи вищої педагогічної школи. Разом з тим цей розвиток залежить від правильних уявлень про педагогічну діяльність і про навчання як про щось, що забезпечує можливість здійснення життєвого покликання. Зазвичай, склалась думка, що становлення майбутнього вчителя відбувається в межах часу навчання його у вищому навчальному закладі. Але студент приходить сюди вже з певними знаннями, сформованими вміннями, із певними уявленнями про професійну діяльність, які він отримав протягом попереднього періоду життя (дитячий садок, школа, сім'я). Ще в ранньому дитинстві, в сім'ї, «закладається духовна основа життя: любов до життя і до людей, довіра до оточуючого світу, оптимізм щодо себе і інших, почуття обов'язку, відповідальності» [2]. Це складає гуманістичну складову структури особистості вчителя. В дошкільному віці модель педагогічної поведінки дорослих актуалізується в сюжетнорольових іграх; у догляді за молодшими набувається певний виховний досвід; засвоюється зміст соціально-рольових функцій вихователя. Особливо важливий період для засвоєння дитиною фрагментів педагогічного досвіду дорослих $є$ навчання у школі. Саме тут формується уявлення про особливості педагогічної діяльності, відбувається становлення відношення до професії вчителя. Для молодшого школяра вчитель не тільки авторитет, а для більшості - «ідеал». Саме в шкільному віці, в процесі спілкування з учителем закладаються основи побудови моделі «я - ідеальне» майбутнього викладача. Все це сприяє тому, що студент-першокурсник має власний проект майбутньої професійної діяльності і поведінки, своє бачення професії «вчитель».

Під професійною математичною компетентністю Я.Г. Стельмах [3] розуміє інтегративну властивість особистості, що забезпечує готовність самостійно і відповідально застосовувати математичний інструментарій відповідно до завдань професійної діяльності, а також системоутворювальні компоненти, показники яких у вигляді математичних компетенцій свідчать про теоретичну та практичну готовності випускників вищих професійних закладів до професійної діяльності. Проте низка питань (методичні умови та модель формування математичної компетентності тощо) залишаються недостатньо розробленими.

Ефективність та результативність формування професійних компетенцій значною мірою залежать від викладача. У роботах вчених-педагогів Л.Г. В'яткіна, Н.С. Журавської, Л.М. Журавської, І.І. Кобиляцького, В. Оконя, Л.І. Рувинського, Н.В. Рум'янцевої, В.Ф. Шаталова, М.І. Шевандріна, Ю.Ю. Щербаня та ін., аналізуються різні ролі викладача залежно від міри його втручання в навчальну діяльність студентів: 1 - «лектор» як джерело компетентностей, 2 - «керівник» як дієвий організатор процесу самостійної роботи студентів, 3 - «консультант», що здійснює дієву допомогу студентам при наявності у них значних утруднень у самостійній навчальній діяльності, 4 
- «модератор» - спостерігач, але арбітр, який тільки спрямовує самостійну навчальну діяльність.

Мотивація пізнавальної діяльності характеризує ставлення людини до оточуючого світу і пов'язана з виникненням потреби в його пізнанні. Якщо потреба виражає необхідність, а мета - конкретизовану потребу, то мотиви характеризують внутрішні причини цих процесів. Система потреб і мотивів відображається в інтересах, які мають велику спонукальну силу. Інтерес змушує людину прагнути пізнання, виявляє потреби та мотиви діяльності, і в той же час стає ії метою. Інтереси і мотиви тісно пов'язані і для навчального процесу виступають основою, на якій виникають, закріплюються і розвиваються знання, вміння, навички і практичний досвід студентів. Якщо такий взаємозв'язок існує, то процес пізнання здійснюється активно. Психологія відводить значне місце такому важливому для навчання психологічному процесу, як сприйняття. Сприйняття тісно пов'язане 3 осмисленням і розумінням змісту навчального матеріалу і $€$ важливим фактором успіху в навчанні. Якщо розуміння пов'язане з певним мотивованим напрямком розумової діяльності студентів, то воно виступає головною умовою глибини засвоєння навчального матеріалу, виділення у ньому закономірностей. Важливою властивістю мислення $є$ увага, яка в психології вважається основною формою організації пізнавальної діяльності та початковою сходинкою розуміння. Якщо вдається привернути і зберігати постійну увагу до нового матеріалу, підвищується й рівень активності студентів [1].

Профресійне ж учіння має сприяти осмисленню уявлень про педагогічну діяльність, які сформовані на власному досвіді вчорашнього старшокласника, «наближати його до когнітивної моделі педагогічної науки»; професійне учіння повинне перевіряти відомі ідеї, знайомі питання, узагальнювати, уточнювати у новому світлі, давати їм нове бачення.

Розвиток особистості студента, а значить, і його психологічна готовність до професійної діяльності, на різних курсах має наступні риси: 1) перший курс: адаптація до умов вузівського навчання, залучення до студентських форм життя; 2) другий курс: найбільш напружена навчальна діяльність студентів, загальна підготовка; 3) третій курс: початок спеціалізації, подальший розвиток і поглиблення професіональних інтересів студентів; 4) четвертий курс: перше реальне знайомство зі спеціальністю в період проходження практики, переоцінка студентами багатьох цінностей життя і культури; 5) п'ятий курс: формування чітких практичних настанов на майбутню сферу діяльності.

Професійна самосвідомість студента - усвідомлення студентом себе як майбутнього фрахівця, здатність адекватно оцінювати рівень сформованості професійно важливих якостей, свої досягнення, невдачі й помилки в професійній діяльності. Це психологічний показник успішності професійного розвитку та професіоналізації його особистості, формування відповідального ставлення до майбутньої роботи.

Виробнича (педагогічна) практика - це перше профресійне випробування студента, уявлення особистості про себе як про професіонала, ступінь ідентифрікації її образу з образом професіонала виступає як результат дії мотивації й слугує індикатором мотиваційної сфери особистості, що 
обумовлює ставлення до професійної діяльності. Після практики підвищується самооцінка готовності до самостійної роботи в школі. Виробнича практика впливає і на відношення студентів до педагогічної професії. Це відношення $€$ суперечливим і залежить від конкретних переживань дій студентів. Проте часто породжуються внутрішньо-особистісні конфлікти, які супроводжуються заниженням професійної самооцінки, втрати інтересу до професії вчителя. Саме в такій ситуації студент-практикант потребує підтримки зі сторони методистів, вчителя зі стажем, бо на уявлення студента про себе («Яідеальний») істотно впливає оцінка його як вчителя керівника виробничої практики.

Педагогіка й психологія вищої школи, вдосконалюючи та уточнюючи свої методи дослідження, встановлюють зв'язки з низкою математичних наук (математична статистика, теорія ймовірності, математична логіка, кібернетикою, теорією інформації та інформатикою, з нейропсихологією та нейрокібернетикою, теорією моделювання, 3 соціальними науками (насамперед, із соціальною психологією та соціологією). Ще одна галузь педагогічних знань, яка інтенсивно розвивається, - це дидактика вищої школи - наука про вищу освіту й навчання у вищій школі [2].

Тому, до найважливіших практичних завдань, які постають перед педагогікою й психологією вищої школи в період реформування вищої освіти в Україні, висуваються наступні вимоги:

- створення науково-педагогічної, методичної та психологічної бази для контролю за педагогічним процесом, повноцінністю змісту та умовами психічного розвитку студентів, їх особистісним зростанням і професійним становленням як майбутніх фахівців;

- організація оптимальних форм навчально-професійної діяльності та спілкування студентів для успішного засвоєння ними всієї різноманітності профресійних функцій і необхідних соціальних ролей;

- надання психологічної допомоги та підтримки всіх учасників педагогічного процесу, особливо в періоди особистісних життєвих криз, у тому числі й професійних випробувань.

\section{Список використаних джерел:}

1. Данильчук, О.Н. (2013). Самостоятельная работа студентов как один из организационных факторов кредитно-модульного обучения математике. Socialinis Ugdymas Social Education (Nr.4(36)) 131-141.

2. Дудка, Г.Я. (2011). Класифікація наук в контексті фундаменталізації сучасної освіти. Розвиток педагогічних наук в Україні і Польщі на початку XXI століття, 504-511.

3. Стельмах, Я.Г. (2011). Формирование профрессиональной математической компетентности студентов - будущих инженеров. (автореф. дис. на соискание научной степени к.пед.н.) Самара, Россия. 


\section{SECTION XII. SCIENCES PHILOLOGIQUES}

\section{FOREIGN LANGUAGE IN THE INTERNATIONAL BUSINESS COMMUNICATION}

Maryna Antonivska

teacher

Kyiv National University of Culture and Arts

UKRAINE

Nowadays world is rapidly globalizing and improving, which is reflected in the changing language system. Economic and cultural relations are strongly linked in all countries of the world. Business has an unlimited influence on the development of international relations, which naturally goes beyond the control of one country and leads to the need for international contacts in this field.

Business communication at the present stage of society is the most widespread form of social communication. The globalization of economic activity is gaining momentum: the geography of partner countries is expanding, the number of international companies with foreign partners is increasing, and the links between them are increasing. New economic and business development prospects have enabled the broad masses of the population to engage in commercial and organizational activities.

All this is reflected at both production and management levels of organizations. There is a need for employees' special training in order to increase their competence not only in professional terms, but also in the culture of business communication. Mastering the basics of oral and written business language is the key to successful negotiations, business meetings, telephone conversations, correspondence, documentation. These circumstances were the impetus for learning linguistic forms of business communication and enhancing the linguistic competence of people engaging in social and legal relations with each other. Business letter, like any business text, is a genre of formal business style and is a written and spoken work that has all the basic general text characteristics. Appeal to the syntactic level of business text is determined by the fact that grammar plays a major role in the construction of structural features of the text. Pragmatic factors are an important element in the choice of expression structure.

Nowadays, due to the significant changes that have taken place in our economy, its integration into the world market, whose international language is English, there is an urgent need to train professionals who speak business English. English is recognized as a language of international communication not only in business but among its various uses (international negotiations, air and sea navigation, etc.), this field is distinguished by its considerable specialization at different levels of the linguistic hierarchy. Business language is regulated not only in vocabulary, syntax, but also in graphics, the use of paralinguistic means, various communication channels, etc. Many people around the world, for whom it is not native, actively use it in their daily professional activities. Due to the expansion of foreign economic 
relations of our country, the increase in the number of people involved in business activities, international standards, in particular, the norms and rules of business English, are penetrating into Ukrainian language.

Over the last 10-15 years, the gap between theory and practice has narrowed significantly in this area.

However, despite the fact that many aspects of business English have already become the subject of detailed study, the real life and English patterns, as a means of oral and written business communication, still requires scientific reflection. Particularly noteworthy are the peculiarities of English business communication translation.

References:

1. Bakhov, I. (2009). Intercultural aspect of future translators professional competencies formation. Scientific research. Experience. Kharkov.

2. Canale, M. \& Swain, M. (1983). From communicative competence to communicative language pedagogy. Language and Communication. London: Longman.

\section{FUNCTIONAL CHARACTERISTICS OF INTERNATIONAL ECONOMIC TERMINOLOGY}

Tetiana Pavlus

applicant for bachelor degree in Germanic languages and literatures (translation included)

National Transport University

Liudmyla Moshkovska

Senior lecturer

National Transport University

UKRAINE

With the rapid development of logistics in Ukraine and the processes of deepening international economy, including trade relations, intermodal transportation chains, the lexical systems of English and Ukrainian languages are being constantly enriched with new economic units. Due to the improvement of different branches terminology systems and subsystems with special ordering of their components in both English and Ukrainian languages are also updated by a great variety of neologisms, author's terms, international lexicon. So, one of the urgent tasks of modern linguistic science is the internationalization of economic, in particular, customs terminology.

Investigation of the morphological structure of terms, their types according to the sphere of application, combinability properties in the context of the sentence or the whole text enables to identify and classify newly formed or borrowed terminological units for better understanding their semantic and functional loading and avoiding the ambiguity of their interpretation. The process of internationalization of English economic terms contribute to the development of general linguistic orientation (which is lexical systems' interrelations in our study), the expansion of opportunities 
for their semantic analysis, rapid and long memorization of special terminology as well as the constant replenishment of Ukrainian economic vocabulary. The tendency towards internationalization is particularly notable in the formation of customs terminology system due to the significant impact of related economic operations, legal procedures, transport services and tourism at the national and international levels. Such integration of branches leads to the creation of a common morphological and lexical fund in the language system. The internationalization of terminology becomes a necessary means of communication in the period of great social change, intensification of international communication and economic contacts. In this regard, both in the practice of international communication and in the linguistic science, there is a growing concern about possible correlations of national vocabulary and internationalisms which must comply with phonetic and lexico-grammatical norms of another language so that their availability will enrich another lexical system without contradicting it or supplanting national lexemes.

There is no consensus among linguists about the content of the concept of "international language fund" regarding the number of languages in which the borrowed word must be used in order to be considered international. Thus, Danish linguist Otto Jespersen [1] considers the international character of vocabulary not in the number of languages in which the word is used, but in the number of people who use this or that linguistic unit. Most experts are of the view that in order to be international, terms must be used in at least three widespread non-related languages of the world and should function in different fields of science. According to the research made, the internationalisms taking on the function of economic terms in the Ukrainian and English languages are the words having a similar meaning, sounding form and undergoing transliteration or transcribing techniques in translation. Based on syntagmatic relations, many internationalisms of nonterminological character or terms-internationalisms combining with customs terms within the sentence form new customs terminological units that denote names of customs documents, organizations, procedures, dues/ taxes and services: input dumping, customs tariff, import duty, customs certificate, documents on customs clearance. They are mainly two componential noun clusters with the head wordinternational lexeme and can be illustrated by the following models: Internationalism + Term, Term + Internationalism, Internationalism + Prep. + Compound Term.

Internationalization of the economic terminological fund manifests itself in the similarity of the content and expression planes as well as the structural forms of the new economic terminology of English and Ukrainian languages which contributes to their semantic community. Therefore, the internationalization of language systems for special purposes implies, above all, their harmonization at the conceptual and functional levels. The use of internationally standardized definitions of concepts is a very important aspect of trade and other economic processes facilitation [2]. Under such circumstances fruitful cooperation, cross-cultural links, trade, joint ventures, other forms of international activity and professional communication will make it possible for linguists to further advance the replenishment process of the Ukrainian lexical system.

\section{References:}

1. Jespersen, O. (1928). An international language. London: Allen and Unwin.

2. United Nations. Trade facilitation implementation guide. Retrieved from http://tfig.unece.org/contents/customs-terminology-trade-definitions.htm 


\section{ТЕХНИКАЛЫҚ АУДАРМАНЫҢ ТЕОРИЯ ТҰРҒЫСЫНАН ТУЫНДАЙТЫН КЕЙБІР ҚИЫНДЫҚТАРЫ ТУРАЛЫ}

\section{Маржан Қалжанқызы Нұрмаханова}

фрилология ғылымдарының кандидаты, тіл білімдері кафедрасының доценті Алматы энергетика және байланыс университетінің

Эльмира Турсынқызы Ахметова
аға оқытушысы
Алматы энергетика және байланыс университетінің
ҚАЗАКСТАН РЕСПУБЛИКАСЫ

Қазіргі қоғамдағы ақпараттық үрдістер ғаламдық сипатқа ие. XX ғасыр бізге ғылыми-техникалық прогресс, ақпараттық технологиялар және цифррлық экономика дәуірін ашты. Әлем дамудың жаңа деңгейіне жетті. Мыңжылдық өзгерудің ерекше белгісі - ынтымақтастық пен мемлекеттердің өзара түсінушілігі.

Қазақстан тарихи дамудың қазіргі кезеңінде ауқымды ақпараттық ізденіс жағдайында. Қазақстан халқының бүгіні және болашақ тарихи алдағы әлеуметтік, саяси, мәдени, экономикалық, рухани дамуы мәселесі республикадағы аударма ісінің жағдайы туралы мәселені алға қойды. Аударма жұмысының ерекше өзектілігі - республикалық интернетті құру, мемлекеттік тілге негізделген байланыс және ақпараттық жүйелерді құру қажеттілігі болды.

Техникалық аударма мәселесін егжей-тегжейлі зерделеу қажеттілігі бұрыннан қалыптасты. Техникалық аудармалар туралы айтатын болсақ, бұл аударма өте қажет, өйткені ол басқалардан айтарлықтай ерекшеленеді.

Техникалық аударманың өзіне тән тілдік ерекшелігі - ондағы терминологиялық сөздердің болуы. Ғылыми және техникалық мәтіндерді аудару кезінде терминнің рөлі маңызды, өйткені ғылыми ұғымдарды нақты терминологиялық түсінігін талап етеді. Дұрыс аударудың негізгі шарты, яғни түпнұсқа терминнің әртүрлі мағынада жеткізуге қызмет ететін аудармашының дұрыс сөздерін таңдау - талқыланып жатқан нәрсені дұрыс түсіну. Шетел елден енген терминді дұрыс түсіну сонымен қатар оның аудармасы үшін дұрыс сөз таңдау мүмкіндігін білдіреді. Терминнің тағдырын (терминді пайдалану, термин жасау) зерттеуші шешеді. Сондықтан, терминнің мағынасын және оны пайдалану заңдылықтарын анықтайтын, ұлттық терминологиялық мұраға сезімтал болып, оның даму болашағын көретін адам. Ғылымның дамуы бұрын белгісіз заттарды белгілейтін арнайы сөздердің пайда болуымен қатар жүреді. Осылайша тіл ғылымға терминология арқылы енеді. Терминдер қатаң шектеулі болуы керек және сөздің, құбылыстың және ұғымның нақты арақатынасы болуы керек. Қазір республика өмірінде болып жатқан өзгерістер, нарықтық экономикаға өту, ғылыми-техникалық прогресс терминологиялық қордың дамуын тездетеді. Терминология өзінің ресурстарын әр түрлі көздерден толықтырады.

Терминдерді аудару мәселесі терминологияның негізгі мәселелерінің бірі болып табылады. Терминдердің қолданылу аясы ғылыми әдебиеттер болып табылады және олар кез-келген ұлттық нақышпен ерекшеленбейді. Терминдердің қажетті сәйкестігін іздеудің қалай жүргізілгені туралы бірнеше мысалдар келтірілген тілдердің тарихын қарастыра отырып, атап айтқанда: 
шет тілінен тамыр алу арқылы, бұрыннан бар сөздің мағынасын шамалы немесе ұқсастырып аудару арқылы ғылыми терминологиямен жұмыс жасаудың қиындығын көрсететін келесі факторлар анықталды: 1. Ғылыми терминологияның қолданысы кең, сондықтан аудармашы үшін ғана емес, сонымен қатар маман үшін де барлық терминдерді білу мүмкін емес. 2. Елде бірігу мәселесі, сондай-ақ терминдердің тілдерге қосылуы. Өздеріңіз білетіндей, термин дегеніміз - бұл білімнің немесе қызметтің арнайы саласы ұғымын білдіретін сөз немесе сөз тіркесі, ал техникалық терминология ғылым, технологиялар мен қолөнер жетілдірілген сайын үнемі өзгеріп, байыта түсетін тілдің қозғалмалы динамикалық бөліктерінің бірі болып табылады.

Жалпы, ғылым тілі төмендегілерді кеңінен қолданумен сипатталады.

- өзге тілден енген, халықаралық сөзжасамның модельдері және лексикалық элементтер (макро-, микро-, интер-, метр, граф, қосымша және басқалары: интерполяция, экстраполяция, микрометр);

- жұрнақтарсыз зат есімдер: қысу, домер, артық жүктеме;

- іс-қимыл, жай-күйін, қозғалыс, күй білдіретін зат есімдер - ние, -ость, ство, -ие, -ка, -ция және т.с.с. ұғымдарын білдіретін зат есімдер: астатичность, трассирование, аппроксимация, абсорбция, съемка;

-ик, -ал, итель, -ен сын есімдер: геоцентрлік, микрометриялық, орбиталық, жерге орналастыру;

- салыстырмалы сын есімдердің негізінен қалыптасқан зат есімдер: су мөлшері, мысалы;

- қисық типтегі негізделген формалар: дөңгелек, салмақ орташа;

- зат есім -тел, құралды, құралды, қимыл жасаушыны білдіреді.

Термин бір мәнді емес, синонимдік мағынасыз, контекске қарамай, термин терминмен аударылған - толық және абсолютті эквивалент. Терминнің аудармасы түпнұсқа тілінің (ТT) сөзін аударушы тілдің (АT) сөзімен алмастыру қажет емес.

Ғылыми мәтінде, яғни өзінің табиғи ортасында термин номинативті рөл атқарады: бұл нақты тұжырымдаманы білдіретін белгі. Мысалы, егер орыс тілінің күнделікті сөйлеуіндегі сөз өрісі бірнеше ұғымды білдірсе, онда ғылымитехникалық мәтінде бұл сөз: «кез-келген күштердің әрекеті көрінетін кеңістік»: электромагниттік өріс, гравитациялық өріс. Ғылыми терминология - қазақ тілінің сөздік қорын толықтыратын маңызды қабаттардың бірі.

Қазақ тілінің қазіргі даму кезеңінің ең айқын көрсеткіші - әлеуметтікэкономикалық, саяси және әлеуметтік өмірдің жаңа құбылыстарының, ғылымның, техниканың, өндірістің, мәдениеттің, өнердің әртүрлі салаларына қатысты жаңа атаулардың пайда болуын бейнелейтін көптеген неологизмдердің пайда болуы. Концентрация - шоғырлану, концентрация. Коэффициент полезного действия - пайдалы әсер коэффициенті және т.б. Сөйлемдегі бір тілден екінші сөзге дұрыс аударма немесе синтаксистік үйлесімділік лексикалық үйлесімділіктен кем емес. Егер ғылыми-техникалық аударманың дәлдігі туралы айтатын болсақ, онда ол сөзбе-сөз және мағыналық болуы мүмкін.

Әдеби дәлдік грамматикалық оралымдарды механикалық көшіру, терминологиялық және лексикалық құралдарды дұрыс таңдамау және сөйлемнің бастапқы құрылымын өзгертпеу нәтижесінде қалыптасады. Мұндай дәл аударма сөзбе-сөз аудармаға жақын және оны нашар аударма ретінде қабылдауға болады.

Аударма сауаттылығы: 
- қазақ тіліндегі эквиваленттерді дұрыс таңдамау, «жалған аудармашылар»;

- стандартты емес немесе стандартты емес терминологияны қолдану;

- қазақ тіліне тән емес грамматикалық құрылымдарды есептеу;

- мәтіндерді негізсіз қысқарту;

- орынсыз сөзді жоғалту;

- түсіндірме сөзді қолдану;

- орысша сөйлемнің сөз тәртібін көшіру.

Семантикалық дәлдік екі тілдің стильдік ерекшеліктерін терең түсіну қайнар көзі мен аудармашы - және сөйлемдегі олардың құрылымы мен сөз тәртібіндегі айырмашылықтарды білу, оның мағынасын сақтау үшін түпнұсқа әрпінен алыстау мүмкіндігі, аударушы тілдің оралымдарын қолдана білу. Мазмұнды дәл беру (семантикалық дәлдік) ғылыми-техникалық әдебиет аудармашысынан сипатталатын тақырыпты және орыс және қазақ тілдерінің ерекшеліктерін жақсы білуін талап етеді. Мысалы, шығарылғаннан деген сөзге өосылатын жұрнақтардың тәртібін сақтау.

Қазақ тіліндегі етістіктің негізіне 2жақтың жекеше түрінің бұйрық райы алынады (кел, айт, бер, жаса).

Мысалыға алсақ шық етістігінің -ар шартты рай жұрнағы болып келеді (және де қ қатаң дауыссыз Ғ ұяң дауыссызға айналады ).

- ыл - суффф. Ырықсыз етіс

- ған - суффр. Өткен шақтың есімше фрормасы

- нан -шығыс септік жалғауы.

Орыс және қазақ тілдерінің лексикалық үйлесімділігі френомені зерттелмеген тақырып, бірақ мәтіндерді бір тілден екінші тілге аударған адамдарға таныс, мысалы:

Старый человек - Кәрі адам, Карт кісі;

Старые взгляды - Ескірген қөзқарас;

Старая книга - Ескі кітап;

Решить задачу - Есепті шығару;

Снять пальто - Пальто шешу;

Снять головной убор - Бас киімді алу;

Снять кино - Кино түсіру;

Снять напряжение - Шиеленісті жою;

Берілген мысалдар қазақ және орыс тілдеріндегі лексикалық үйлесімділіктің мысалдары болып табылады.

Лексикалық үйлесімділік / сәйкессіздік мағынасына жақын аударманы жүзеге асыруда үлкен рөл атқарады.

Сөйлемдегі бір тілден екінші сөзге дұрыс аударма немесе синтаксистік үйлесімділік лексикалық үйлесімділіктен кем емес.

Техникалық мәтінде сөйлемдегі сөздердің реттілігінің ақпараттық рөлін аудармашы ескеруі керек, осылайша алынған аударма мәтіні түпнұсқа мәтінінің мағынасын жеткілікті түрде көрсетуі керек. Сөздіктерде орыс тіліндегі етістіктердің сөйлемнің бағыныңқы бөлігімен синтаксистік сәйкестігі мүмкіндігі әрдайым ескеріле бермейтіндігін, синтаксистік вербальды бақылауды жүзеге асыратын орыс жағдайлары мен предлогтарының дұрыс мағынасын дәл табу мүмкін емес екендігін мойындауымыз керек. Бұл орыс тілінен қазақ тіліне аударудағы кейбір қателіктерді түсіндіреді.

Ғылыми-техникалық мәтіннің жеке сөйлемдерін аударудың мысалын қарастырыңыз. 
Аударманың 1-нұсқасы. Қара түсті және асыл металдарды өндіру мен өндірісі ертеден-ақ адам баласы мен қоғамнын жасампаз еңбегінің аса маңызды бөлігін құрайтыны белгілі боған. Бұл қөп жағдайда елдің экономикалық қуатты мен оның әлемдік аренадағы саяси салмағын қөрсетеді.

Аударманың 2(түзетілген)нұсқасы. Ертеден-ақ адам баласы мен қоғамның жасампаз еңбегінің аса маңызды бөлігін құрайтың болып қара, тұсті және асыл металдарды қазу мен өндіруі табылады да, көптеген сәттерде елдін экономикалық куатты мен оның әлемдік аренадағы саяси салмағын көрсетеді.

Алғашқы аудармашы орыс тіліндегі жалпы сөйлем мүшелерін (мысалы, қатысушылық, қатысымдық айналым) ретке келтіру тәртібін қазақша бере алмады және бір жағдайда қатысушылық бұрмалану арқылы қиындаған сөйлемді екі жай сөйлемге айналдырды, ал екінші жағдайда сөйлемдегі сөз тәртібін өрескел бұзды. қазақша нұсқасының мағынасын түсіну.

Техникалық терминдерді тұрақтандыру мен жүйелеуде терминологиялық сөздіктердің маңызы зор. Салааралық терминологиялық сөздіктердің типтік мысалы - әртүрлі елдерде таратылған политехникалық сөздіктер.

Ғылыми-техникалық әдебиеттерді аударуға қойылатын басты талап аударманың түпнұсқаға сәйкестігі. Бұл сөз латынша шыққан (лат. Adaeguatus -тең, дұрыс, жақын). Ғылыми-техникалық аударманың жеткіліктілігіне ақпарат, ғылыми-техникалық дәлдік және түпнұсқаның стилистикалық ерекшеліктерін ескере отырып қол жеткізіледі.

Тиісті аударма түпнұсқаны толықтай алмастыра алады, бірақ мағынасы сақталады. Мұндай аударма эквивалент деп те аталады (лат. Aeguivalens балама, балама, эквивалентті) немесе түпнұсқа (гр. Aythentikos - түпнұсқаға сәйкес, жарамды, шынайы, дереккөз негізінде). Бүкіл аудармада сол термин ұғымды немесе тақырыпты білдіру үшін қолданылуы керек. Сіз кез-келген кәсіпорында қабылданған жергілікті терминдерді, сондай-ақ архаизм терминдерді қолданудан бас тартуыңыз керек. Мақсатты тілдің барлық грамматикалық нормаларын сақтау керек, күрделі грамматикалық құрылыстарды болдырмау керек, ал аударылған ақпарат ең қарапайым және түсінікті (қол жетімді түрде) көрсетілуі керек.

ФИТ Халықаралық аудармашылар федерациясы Дубровникте қабылдаған «Аудармашының хартиясы» (Югославия, 1973): «Аудармашы өзі аударатын тілді жақсы білуі керек, ең бастысы, ол аударып жатқан тілді жақсы білуі керек» (1 бөлім) , 6-тармақ).)

Сонымен, екі тілді де жақсы білетін аудармашы да интерпретациялық аударманы орындауға және оның мазмұнын түсінуге, жаңа сөзді білуге және шетел тілінің мәтіннен оның мағынасын түсінуге міндетті. Сонда ғана сапалы аударманы жүзеге асыру үшін қажетті негізді қамтамасыз етуге болады. Жоғарыда айтылғандарды қорыта келгенде, техникалық аударманың тағдыры мен тәжірибесі аудармашының біліктілігі мен тәжірибесіне байланысты болады екен.

\section{Әдебиеттер тізімі:}

1. Денисов, П.Н. (1989). О некоторых общих аспектах изучения языков науки// Современные проблемы терминологии в науке и технике. Наука. Москва, Росиия.

2. Жаксылыков, А.Ж. (2006). Актуальные проблемы организации переводческого процесса в современном Казахстане. КазНУ. Алматы, Казахстан. 


\title{
ТЕХНИКАЛЫК ЖОҒАРЫ ОКУ ОРНЫДАРЫНДА ҚОЛДАНЫЛАТЫН ТЕРМИНОЛОГИЯЛЫҚ СӨЗДІКТЕРДІ КҰРУ ПРИНЦИПТЕРІ
}

\author{
Маржан Қалжанқызы Нұрмаханова \\ филология ғылымдарының кандидаты, доцент \\ Алматы энергетика және байланыс университеті \\ Эльмира Турсынқызы Ахметова \\ аға оқытушы \\ Алматы энергетика және байланыс университеті \\ КАЗАҚСТАН РЕСПУБЛИКАСЫ
}

Энергетика, радиотехника және жылу энергетикасы бойынша студенттер сөйлемдерді еркін оқи алады, мәтіннің мағынасын дұрыс түсінеді. Бірақ кезкелген тілдің ғылыми стилінің негізгі компоненті - арнайы сөздер мен тіркестер, яғни терминдер болып табылады. Кездейсоқ және сирек кездесетін лексикалық және грамматикалық материалдары бар оқулықтар мен оқу құралдарының өте көп болып кетуі қазіргі терминологияның ең қарамақайшылықты мәселелерімен байланысты - терминді терминдік емес терминнен бөлінген әдістер мен терминдердің шектеуі, сонымен қатар термин еместерден терминдерді шектеу мәселесімен байланысты сұрақ тудыртатын заманауи терминдермен тығыз байланысты болады.

Ғылыми терминология - қазақ тілінің сөздік қорын толықтыратын маңызды қабаттардың бірі. Қазақ тілінің қазіргі даму кезеңінің ең айқын көрсеткіші әлеуметтік-экономикалық, саяси және әлеуметтік өмірдің жаңа құбылыстарының, ғылымның, техниканың, өндірістің, мәдениеттің, өнердің әртүрлі салаларына қатысты жаңа атаулардың пайда болуын көрсететін көптеген неологизмдердің пайда болуы.

Ғылыми-техникалық мәтінді аудару кезінде көп жағдайда олар аударма тілінде (АТ) бұрыннан бар дайын терминдерді қолданады. А.С. Гердтің «Ғылыми-техникалық лексикография негіздері»[1] атты кітабында әр түрлі терминологиялық сөздіктерді құру принциптерін сипаттайды: дереккөздерді таңдау, сөздік қорын қалыптастыру, мағыналарын түсіндіру тәсілдері.

Көбінесе терминологиялық сөздіктердің (ТС), ұсынылған терминдердің тізімдерінің, терминологиялық стандарттардың болмауы, классификаторларды, рубрикалар мен ақпараттық тезистерді әзірлеу қажеттілігі туындайды. Салааралық ТС мысалы ретінде әртүрлі елдерде кеңінен таралған политехникалық сөздіктер болып табылады. ТС негізгі көздері - жетекші ғалымдар мен практиктерге тиеселі білімнің осы саласына қатысты монографиялар мен мақалаларды жинақтау болып табылады.

Көптеген университеттік оқулықтар қызығушылық тудырады, өйткені оларда ғылымның ұғымдары мен терминдерінің ең нақты және дәл анықтамалары бар. ТС-ге ірі энциклопедияда көрсетілген, сонымен қатар салалық энциклопедиялар мен сөздіктерде келтірілген саланың барлық терминдері енгізілуі керек. 
Сөздіктерде орыс тіліндегі етістіктердің сөйлемнің бағыныңқы бөлігімен синтаксистік сәйкестігі мүмкіндігі әрдайым ескеріле бермейтіндігін, синтаксистік вербальды бақылауды жүзеге асыратын орыс тіліндегі септіктері мен жұрнақтарының дұрыс мағынасын дәл табу мүмкін емес екендігін мойындауымыз керек. Бұл орыс тілінен қазақ тіліне аударудағы кейбір дқрекі қателіктерді түсіндіреді.

Оқу терминологиялық сөздігі, біздің ойымызша, бағдарламаның барлық мәтіндік материалдарын көрсетіп, оқу мәтінінде кездесетін барлық терминдерді қамтуы керек, ал терминдердің белсенді сөздігі ең аз болуы керек, оған осы мамандық бойынша ең көп таралған (ең жиі кездесетін) терминдер ғана енуі керек.

Біз «Радиотехника, электроника және телекоммуникациялар» мамандығы терминдерінің екі тілді сөздіктерінің түсіндірмелері мен әдістемелік ұсыныстары бар электрондық файл құрастырдық, сөздікке енгізу үшін көрсетілген мамандық терминдерінің тізімін таңдадық. Қол жетімді және сәйкес оқу сөздіктерінің ауқымы кең.

Келесі сөздіктер біздің назарымызға алынды: «Техникалық терминологиялық сөздік», 50000 терминнен тұрады және практикалық бағытқа ие, құрастырушы Құдайбергенов Р.[2]. Терминді басқа тілге аударғанда бір емес, бірнеше мағына беріледі. Негізгі сөз (мағынасы бойынша) орналасқан жері бойынша бірінші сөз ретінде берілген, әртүрлі техникалық анықтамалық кестелер әдістемелік негізделген. Бұл сөздіктің принциптерін белгілі бір мамандыққа арналған сөздік қорды құру кезінде қолдануға болады.

Авторлары А. Берікұлы, Шайхин Б.М. «Қазақша-орысша, орысша-қазақша терминологиялық сөздік» [3] атты сөздік құрылысын қолданушыға қол жетімді етуге тырысты. Сөздіктің артықшылығы - ол оқу үрдісімен тығыз байланысты. Бұл сөздікті екі тілді лексиканы құрастыруға негіз ретінде алуға болады.

Редактор Е. Арын «Орысша-қазақша түсіндірме сөздігіне» (физика) [4] электроника және байланыс, электротехника саласындағы ең көп таралған 1700-ге жуық терминдерді енгізді. Түсініктеме қазақ және орыс тілдерінде беріледі, мысалы: радиобайланыс - радио толқындарының көмегімен жүзеге асырылатын электр байланысының түрі; радио байланстары - радиотолқын арқылы атқаратын электр байланысының түрі. Бір аудармасы жоқ терминдерге баса назар аударылады.

Редактор А. Ю. Ишлинский «Политехникалық сөздігін» [5] анықтамалық ретінде қарастырған. Ғылыми-техникалық өрнектерді түсіну мен қолдануды жетілдіру, оларды инженерлік есептеулерде қолдану үшін әртүрлі техникалық кестелер берілген: үйкеліс коэффрициенттері және т.б.

Әзірленетін оқу сөздігін құрастырған кезде қысқартулардың үлгілері ұсынылған. Б. Б. Ағатаеваның «Орысша-қазақша терминологиялық сөздігі оқу құралы» [6] жоғарыдағылардан құрылымы жағынан өзгеше. Орыс тіліне аударылған барлық терминдер оқу мәтінінен таңдалады, олардың қазақ тілінде түсіндірмесі берілген, мысалы: связь - байланыс; а) адамдар арасында ақпараттың берілуі; б) адамдар арасында хабардың берілуі. Бұл құрылымды жаңа бағыттағы мамандықтар бойынша оқу сөздігін құрастыруда пайдалануға болады. 
Терминдер сөздігін жасаудағы алғашқы тәжірибеміз сөздікте «бүтінніңбөлігі», «тегі-түрі» немесе онымен байланысты әр түрлі ассоциациялық қатынастарға қатысты әртүрлі кәсіби ұғымдарды білдіретін сөз тіркестерінің болуы керек екенін көрсетеді. Студент 150 жаңа терминді үйренуі керек. Оқу лексикасының жалпы көлемі 100-ден 200 бірлікке дейін, оны 1, 2, 3 курс студенттері оқытушымен және сабақтан тыс өз бетінше оқу барысында оқиды. Осындай бірқатар терминологиялық бірліктерді игере отырып, студент өз мамандығы бойынша мәтіндерден ғылыми ақпаратты оңай ала алады, өйткені лингвистикалық статистикаға сәйкес алғашқы кең таралған сөздер мәтіннің немесе сөйлесудің 80\% құрайды. Студенттер, ең алдымен, тіпті егер термин жалпы қолданыстығы (бастапқы) мағынадан басталып, әртүрлі бағыныңқыларға қатысты болса да көп мағыналы терминдерге бағытталуы керек.

Жоғарыда келтірілген сөздіктерді талдау негізінде біз:

1) студенттерге терминдердің барлық мағынасын емес, тек мамандандырылуына тікелей қатысты терминдерді ұсыну керек;

2) өйткені құрылған сөздіктер оқуға арналғандықтан және олардың мақсаты ретінде осы сала бойынша көптеген сөздер мен сөз тіркестерін қосуды мақсат етпейді, студенттер өз мамандықтары бойынша бағдарламалық әдебиеттерді оқу барысында кездесіп қалуы мүмкін жағдайларды ғана бейнелеу;

3) термин аударылғаннан кейін аударылған тілде қысқаша түсініктеме беру;

4) қазақ тіліне аудармасы бар интернационалдық сөздерді қосу.

\section{Әдебиеттер тізімі:}

1. Герд, А.С. (1986). Основы научно-технической лексикографрии. Издательство Ленинградского университета. Ленинград, Россия.

2. Кудайбергенов, Р. (2009). Технический терминологический словарь. Издательский дом «Таймас».Алматы, Казахстан.

3. Берикулы, А.Б., Шайхин, Б.М. и др. (2000). Казахско-русский, русско-казахский терминологический словарь. Электроника, радиотехника и связь. Рауан. Алматы, Казахстан.

4. Арын Е. (ред). Русско-казахский толковьй словарь. Физика. (2006). Павлодар: Павлодарский государственный университет им. С. Торайгырова.

5. Ишлинский А. Ю. (ред). (2000). Политехнический словарь. Москва, Россия.

6. Агатаева, Б.Б. (2004). Многоканальная связь. Русско-казахский терминологический словарь-пособие. Алматы: Гылым. 


\title{
THE COMMUNICATIVE SITUATION IN THE BROADCAST POLITICAL INTERVIEW
}

\author{
Tetiana Striuk \\ Ph.D. student \\ Zaporizhzhia National University \\ UKRAINE
}

Social conditionality of language use attracts attention not only psychologists, sociologists, but also linguists. The interest in the processes of speech generation and its impact on society noticeably intensified. In this context political discourse becomes a tool for manipulating public opinion, because the role of the media as a mediator between politicians and people in a democratic society is undeniable. The components of communication and their functions were described by F. Batsevich, R. Jacobson, U. Eko, J. Lotman and others. Despite the numerous publications on communicative linguistics, the psycholinguistic bases of communication between the politician and the journalist remain a relevant source for studies.

G. Pocheptsov emphasizes that the end of the twentieth century took communication processes to a new level. It is about the phenomenon of information wars (by E. Tofler's definition) [6]. Consequently, the researcher identifies elements of the communication process: the target audience, the channel, the goal, the communicative knowledge, the context [6]. For example, F. Batsevich refers to the components of communication: the addresser (the speaker), the addressee, the message, the communication channel, the information (communicative noise), filters, the feedback, context and situation [6]. A similar model is followed by O. Issers [2]. The scientist pays special attention to the techniques of influence on the interlocutor and the choice of optimal language means, defines a person as a subject and object of linguistic influence. In view of the foregoing, it seems appropriate to consider the psycholinguistic basis of the communicative situation in the broadcast political interview genre.

The purpose of the article is to describe the main psycholinguistic features of the communicative situation in a political broadcast interview. According to the purpose of the research, the following tasks are set: to consider the existing approaches to studying the communicative situation in general; identify the psycholinguistic aspects and roles of communicators in political broadcast interviews.

The exchange of information in the modern world is not only a communicative act but also assumes the functions of a political, sociological lever intentionally aimed at the addressee. It is important to distinguish the term of «interaction» (set of connections and interactions of people, societies, subjects in which information, experience, skills, and performance are exchanged) [1] and the term of "communication» (semantic and ideally meaningful aspect of social interaction) [1].

Considering the fact that we are interested in the political broadcast interview, it is necessary to determine the peculiarities of socio-symbolic regulation of the behavior of the interlocutors (for example, the politician and the journalist or journalists) [5]. Modern pragmalinguistics studies speech acts as a unity of three components: locative, illocutionary and perlocutionary [5]. The perlocutionary effect can be achieved by hidden influence, using not explicit but implicit means (in 
particular, implicature or hidden content). The hidden influence can arise not only because of the author's pre-conceived efforts but also by itself due to the peculiarities of the recipient's perception and social experience. The unintentional perlocutionary act sometimes leads to certain actions of the addresser, such as misspellings, incorrect links, etc. It is mainly characteristic of oral speech [5].

The political broadcast interview is an implementation of the above-mentioned speech acts, so it is advisable to consider their typology on different grounds. The Ukrainian linguist G. Pocheptsov distinguishes the following types of communicative-intentional content: the approval; the promise sentence; the threat sentence; sentences that have a structural question mark [5]. The main components of communication in terms of speech act are the addresser (speaker), the addressee (listener) [5].

O. Feldman, K. Kinoshita, and P. Bull conclude that broadcast political interviews have their own distinctive features and a defined set of rule and norms dominated by the roles and functions of the interviewer(s) and the interviewee(s). First, these interviews are staged performances that take place with the participation of journalist(s) and political officer(s) or expert(s) and in which the ultimate addressee is absent from the actual event. The interview is enacted for the benefit of an "overhearing audience" whose probable expectations shape what is being said and how. Both the interviewer and the interviewees (politicians or experts) will have the general viewers in mind. Second, there is the pattern of "turn-taking system" that noticeably defines the conflicting functions of interviewer(s) and interviewee(s) as both are working to generate discourse for the "overhearing audience" in a two-way process [7].

In the political broadcast interview, it is advisable to distinguish the role of a journalist who is the "translator» of the society's sentiment and the coordinator of the interview script. That is, a journalist mediates between the addresser and the addressee.

P. Zernetsky proposed models of the following combinations of interconnections between components of a speech communication situation: addressee-oriented speech acts; interpersonal-oriented speech acts; cognitively oriented speech acts (This can be described by the scheme "Objective - message»). Accordingly, according to the E. Hirsch's theory of cultural literacy, a sufficient level of cultural literacy is a prerequisite for intercultural communication, which implies an understanding of background knowledge, values, psychological and social identity inherent in a particular culture [5]. Therefore, such knowledge determines the willingness of the listener to interpret an illocutionary or perlocutionary act.

O. Kuzmenko states that the essential feature of the interview is that the listener (viewer) feels free to be able to draw their conclusions about the interviewee, despite the interviewer's probable attempts to impose some position on the audience [4]. It is advisable to mention G. Pocheptsov's statement, which is that a successful communicator conducts his communication in a proven way. This is a variant of an actor that anticipates the reaction of the audience, as he has extensive experience of the performances [6].

For example, the following components of communication significantly affect the format and course of the television debate or television interviews (in view of its dialogical form) and at the same time regulate the perception of the recipientviewers: kinetic (gestures, facial expressions) [3]; proxemic (modeling of communicative space and conditions of communicative act) [3]; phononics (features of intonation, phonics, pauses) [3]. 
The viewer as the end consumer of the message [1] can evaluate the interviewee's behavior and communicative intentions (the intended or intuitive intent of the addresser who determines the internal program of speech and the way to implement) [1]. Communication strategies are flexible and depend on pragmatic factors [1]. The implementation of a journalist's intentions and politics are limited situation and rules of communication, communicative laws [1], social norms.

The situational context of communication [1] in a political television interview is historically predetermined to cover the most pressing issues, key events that bother people, from the first person, that is, the President. The socio-psychological dimension [1] is a dominant type of communication. It is right to point out, $\mathrm{N}$. Kondratenko, that the mass media direct and sometimes simulate political communication in the right direction, creating a special reality similar to the author's fictional world. But if in the text the reader doesn't equate objective reality with the described author, then in political discourse, on the contrary, the created world is replaced by the real [3].

Conclusion. This study demonstrates that the communicative situation in a political broadcast interview is governed by the intentions of the communicators. A comprehensive study of the communicative roles of politicians and journalists in a television interview is promising.

\section{References:}

1. Batsevich, F. S. (2004). Osnovy komunikatyvnoi linhvistyky. Kyiv.

2. Issers, O. S. (2003). Kommunikativnye strategii i taktiki russkoj rechi, (3 edition). Moscow. [in Russian].

3. Kondratenko, N. V. (2007). Ukrainskyi politychnyi dyskurs. Tekstualizatsiia realnosti. Odesa.

4. Kuzmenko, O. Y. (2015). Osoblyvosti komunikatyvnoi sytuatsii interviu ta yiyi skladnykiv. Science and Education a New Dimension. Philology, III(9), 58 - 61 [in Ukrainian].

5. Kuzmenko S. I. (2012). Osnovy psykholinhvistyky [in Ukrainian].

6. Pochepcov G. G. (2001). Teoriya kommunikacii. Moskva [in Russian].

7. Feldman, O., Kinoshita, K. \& Bull Peter B.. (2015). Culture or communicative conflict: The analysis of equivocation in broadcast Japanese political interviews. Journal of Language and Social Psychology, $65-89 . \quad$ Retrived from doi.org/10.1177/0261927X14557567 


\title{
THE CONCEPT «IDIOSTYLE» AND ITS STRUCTURE IN CONTEMPORARY LINGUISTIC STUDIES
}

\author{
Kost' Bohdan Mykhailovych \\ Uzhhorod National University \\ UKRAINE
}

Problems relating to various aspects of style occupy the central place in linguistics. The speculation about the presence of the unique characteristic pattern of language use or the so-called "authorial fingerprint" in each author's style has been put forward as the main hypothesis in most studies.

The interest in the author's linguistic personality arose with the advent of the anthropocentric research paradigm in linguistics when the attention of scholars switched from an object to a subject of cognition. In a narrow sense, a linguistic personality is understood as "a personality expressed in a language (texts) and through a language, a personality reconstructed in its main features based on linguistic means" [1]. In a broad sense, a linguistic personality is "a set of human abilities and characteristics that determine the creation and perception of speech works (texts), which differ in the degree of structural and linguistic complexity, depth and accuracy of reality reflection, and a certain target orientation" [1].

Despite the fact that these definitions are the most common in studies of linguistic personality, there are many other interpretations of the analysed term which is determined by various approaches to research object. Moreover, the term "linguistic personality" is still used synonymously with other concepts: speech personality, communicative personality, communicative competence, idiostyle, speech portrait, etc. This is due to the fact that scholars use different approaches to the study of this phenomenon. However, it is important to note that the presented notions are not complete synonyms: they are reflections of one of a linguistic personality's facets. Thus, the concepts of idiostyle and idiolect are part of the linguistic personality as a whole.

Unfortunately, nowadays there is a terminological confusion of the terms idiostyle and idiolect, moreover, it is not possible to give an exact definition of these concepts, nor to accurately differentiate them, since various sciences are engaged in studying the text. Studying the text only from one point of view would be incomplete since language is a complex, multi-level system.

According to M.N. Kozhina, idiostyle is a combination of linguistic and stylistictextual features inherent in the speech of a writer, as well as of individual speakers of a language. An idiolect is a combination of structurally-linguistic features (stable characteristics) used in the speech of an individual native speaker [2].

Due to the variety of definitions, it can be concluded that they all state that the term idiolect is much broader than the term idiostyle, since it is logical to conclude that each native speaker can have his/her specific idiolect, but not every native speaker can have his/her idiostyle.

There are also other synonyms to the term "idiostyle": individual style, individual manner, individual style of writing, etc. The individual author's style is generally understood as "a system of individual and aesthetic use of means of verbal expression that are specific to a certain period of the development in fiction 
literature" [3]. O.E. Filimonova defines the analysed notion as "the peculiarities of the individual manner of the author's use of language to achieve the desired effect" [4].

According to many linguists, the writer's style is characterized by an individual synthesis of forms of verbal expression and a content plane. M. V. Yermolayev argues that "the writer's language is the structure of his/her life. Style is its special rhythm. To understand correctly the author's language means to feel its emptiness and vastness, to see its insanity and admit it into yourself, i.e. to experience enlightenment» [5].

V.V. Vinohradov uses the term "the author's individual style" and defines it as: "a peculiar, historically determined, complex, but representing the structural unity of the system of means and forms of verbal expression in its development <...> according to his/her (the writer's) artistic intentions, all language means used by the artist are united, internally connected and aesthetically justified in the author's individual style" [6].

The dictionary of stylistic terms under the editorship of L. P. Stolyarova offers the following definition to the studied phenomenon: "an individual style, or idiostyle, is inherent to a certain artist of word or any language carrier, the speech peculiarities of which become the subject of attention" [7]. V. K. Voynov offers the following interpretation: "in the sense in which we speak of the system or the consistency of a language, we can also speak about the system or the consistency of an individual style as a minimal "sub-language", as a combination of sustainable skills of national language use by a separate language carrier" [8].

M. P. Brandes identifies three levels in the structure of the author's individual style: the objective-psychological level, the subjective-psychological level, and the language level. In addition, he introduces the concept of "the style of the epoch", which emerges at a certain period as a manifestation of the nation's cultural development conditioned by the historical situation [9]. We completely share the scholar's point of view since we believe that the individual style does not only reflect psychological peculiarities of the author's personality, but also his/her individual features that are determined by the social consciousness, political, ethnic, and religious peculiarities, national identity of the writer, specific stylistic features of that historic era in which he/she lived and created his/her works.

The basis of the objective-psychological level of the author's individual style is comprised of such features as his/her way of thinking and imagination that have a direct relevance to the design of the content. Thus, M. P. Brandes distinguishes between two types of writers, depending on the character of perception: the visual type and the hearing (acoustic) type [9]. The basis of the subjective-psychological level of the author's individual style consists of expressiveness, emotiveness, qualities, connected with the coordination of language elements into an integral ensemble. The determining factor of this level is represented by such personal qualities of the author as his/her temperament, the type of higher neural activity associated with a varying degree of emotional stress, the type of character. M. P. Brandes writes that, depending on the type of the neural activity, we can distinguish different emotional stress: acute in a choleric, reduced in a phlegmatic [9]. This assertion is debatable, but not meaningless, since, in our opinion, the type of character can influence the author's manner of presentation.

On the language level, the author acts as a practical figure. On the language level, the following features of style can be identified: compliance with the language rules, the "skill" of performance, the use of language means. The language skill of 
the writer, associated with his/her talent, is his/her individual manifestation in the full sense of the word.

In summary, we should note that the author's individual style is commonly understood as a system of individual and aesthetic use of means of verbal expression that are specific to a certain period of fiction literature development. In addition to reflecting psychological peculiarities of the author's personality, individual style also manifests the author's individual features that are determined by the social consciousness, political, ethnic, and religious peculiarities, national identity of the writer, specific stylistic features of that historic era in which he/she lived and created his/her works.

\section{References:}

1. Караулов, Ю. Н. (2002). Русский язьк и языковая личность. Москва: Издательство ЛКИ.

2. Кожина, М. Н. (2006). Стилистический энциклопедический словарь русского языка. Москва: Флинта: Наука.

3. Гвердцители, Л. В. (1983). Язык писателя и национальный литературный язык: (аспект кодифрикации и лексикограффирования). Тбилиси: издательство Тбилисского университета.

4. Филимонова, О.Е. (2001). Язык эмоций в английском тексте. Санкт-Петербург: Изд-во РГПУ им. А.И. Герцена.

5. Ермолаев, М. В. (1998). Безумие языка или язык безумия. Язык и стиль художественного произведения (с. 23 -39). Курган.

6. Виноградов, В. В. (1959). О языке художественной литературы. Москва: Государственное издательство художественной литературы.

7. Столярова, Э.А. (2003). Части речи. О.Б. Сиротинина (ред.) Разговорная речь в системе функциональных стилей. Грамматика. (с. 4-47). Москва: Едиториал. 2003.

8. Войнов, В. К. (1972). Количественный анализ текста для описания индивидуального стиля (автореф. дисс. ... канд. фил. наук). Киев, Украина.

9. Брандес, М. П. (1990). Стилистика немецкого языка. Москва: Высшая школа.

\section{THE SPECIFICS OF THE NOMINATIVE BEHAVIOR OF THE UKRAINIAN CITY DWELLERS IN THE ZOONYMY FIELD}

\section{Svitlana Sablina \\ Ph.D. (Philology), Associate Professor of the Ukrainian language Zaporizhzhya National University \\ UKRAINE}

Stratification of the speech behavior of a modern city dweller is becoming more and more interesting for the domestic and foreign researchers. And urban (and rural) zoonymy is just that illustrative layer of the language that is very sensitive to changes in society and demonstrates, for example, a certain turning point in the aesthetic and sociocultural tastes of modern Ukrainians. The virtual line of the 80s90 s of the twentieth century is considered the one which identifies a turning point in the nominative behavior of Ukrainians: the end of the 90 s of the XX century and the beginning of the XI century were marked by new and fairly clear trends in the nomination of animals. 
This phenomenon was explained by O. A. Stishov [1], in particular, refers to the intensification of public life in these decades, which were marked by significant and deep socio-cultural changes, that have caused significant changes in the language habits and tastes of Ukrainians. Although it is necessary to take into account factors of non-language nature, which now act and influence the change of Ukrainian lexical priorities: democratization of all branches of public life; significant weakening of censorship and self-censorship; changes in the social structure of Ukrainian society; necessity, feasibility, practical needs of the speakers; words fashion - aesthetic tastes of a particular time; search for new expressive means. Almost all of these factors have influenced the modern preferences of Ukrainian citizens. With the rapid development of the sphere of innovative technologies, the spread of multimedia space, nominative priorities of Ukrainians are clearly shown by zoonyms.

In our case, when pets are named by modern Ukrainian citizens, all these factors may be true, but we should not forget about the linguistic and psychological reasons. Moreover, "the possibility of choosing a language tool from a set of nominations does not always have only a linguistic justification. Since the psychological associations that underlie the nomination realities are very different, if not random. This means that not language creates a thought, but a thought leads language" [2].

So, drawing attention to such warnings and chronologization, the purpose of intelligence is to find out the nominative priorities of Ukrainian citizens when naming pets (cats and dogs). The research source was a card catalog created during 20122018 with more than 3,000 city zoonyms (felonyms and kinonyms) based on questionnaires, databases of veterinary clinics, and social media posts (Facebbok, Instagram).

Modern urban zonyony is a surprisingly dynamic and well-developed nominative system that is sensitive to changes in society. Earlier the townspeople often called their pets, taking into account the tradition or guided by the characteristic features of zoonyms [3], but now the trend has changed. For example, in one third of the cases, modern city dwellers name their pets by a person's name. The motivation for a pet to be named by a modern citizen using a person's name is often simple - for many people an animal is another full member of the family. If we take into account that caring for pets is already a social habit and that it is due to modern culture, as the American psychologist Harold Herzog shows [4], it is quite clear why modern city dwellers resort to human names in more than a third of cases when they name cats and dogs.

If, when naming children, people are somewhat limited by nomination opportunities (traditions, harmony, generally accepted registries), then when naming animals, there are no such obstacles, and therefore citizens are free to choose and can fully implement their own imagination. However, in a third of cases the owners of animals still do not come up with occasionalisms, but use ordinary human names. In fact, there is a tendency to name animals the colloquial version of the human name, which is consistent with the household model of behavior of citizens in relation to animals: Asia (from Anna), Archi (from Archibald), Yasia (from Yana), Lili, Lika, Liksi (from Liliia), Niusia, Niushka (from Natalia), Zheka, Zheksa (from Yevhenii), Makha, Mashka, (from Mariia).

However, talking about the relevance of Ukrainian traditional pet names, based on traditional Greek-Slavic human names, it is steadily decreasing, while American 
traditional pet names are becoming more popular among Ukrainian pets owners and are widely used by employees of veterinary clinics, shelters and ordinary animal lovers: Adam, Clyde, Maggie, Rocky, Toby, Lola, Sophie, Sadie. In general, most of the words that came from onyms registered nicknames of modern city animals comes from English ordinary names of people, and previously used Greek-Slavic names are now more and more replaced by Anglicisms: Adel, Berta, Delf, Erin, Kevin, Kollinz, Odri, Ralf, Set, Fiona, Clyde, Maggie, Rocky, Toby, Sadie, Miut, Miuzett, Merry, Merylin, Mikhael, Naomi, Richard.

An illustrative fact of the foreign influence in urban zoonymy is detected in the fact that very often a name of a famous person from the sphere of modern culture (the world of fashion, cinema, politics) is the basis of a felinonym or kinonym. The frequency of such nicknames is symptomatic, and considering the modern nominative fashion, it is not random: Bush, Leon, Armani, Dzhekson, Dysnei, Merylin, Khadson, Adolf, Adams, Barak, Tramp, Oliver, Huchchi, Dekster, Lambert, Ozzi, Stinh, Chak, Kruz, Niuton, Marchelo Mastroiany.

The traditional nicknames of animals include those that with the owners associate with the heroes of literary works, movies, cartoons. With the advent of Disney cartoons, those nicknames that are used in films to denote animals and people became frequently used, and most often modern Ukrainians prefer the names of the heroes of American cinema: Baffi, Chesire, Maila, Nemo, Mario, Panda, Ralf, Roksi, Simba, Urfin, Fiona, Simba, Harfild, Rusalochka, Tom, Mikki, Batman, Homer, Hoblyn, Zorro, Nyndzia, Sylver, Sylvestr Stallone, Rembo, Dzhek.

Another peculiarity of Ukrainian citizens in the nomination of pets - the motivation for choosing a nickname is directly related to ancient mythology, while Slavic mythology is ignored, and, we believe, undeservedly. Especially often mythologemes are the basis of kinonyms, apparently due to the association with the size and strength of an animal. For example, the most common nicknames in Ukrainian from mythologemes for bullterriers and rottweilers are Yupiter, Mars and Zevs. Among the felinonyms associated with Egypt are Kleopatra, Nefertiti, Ramzes.

Whereas years before the nickname of the animal was mainly called upon to carry not only an identificational but also a characteristical function, for example, indicate the time of birth of the animal (Martyn, Berizka), the color or other characteristic of the fur (Ryzhyk, Dymka, Pushok), the specific behavior (Spliukha, Zhulka), now similar internal semantics of zoonyms is being increasingly blurred. The trend towards the selection of loan words, motivated by some fur characteristics, based on which animal owners form occasionalisms: Nehra, Nihera, Blondi, Naiti, Snouch, Blekan, Redik, Redzhyna. This also does not add optimism, because it indicates that the nominative priorities of modern Ukrainian citizens are given to borrowing. This is further prooved by the eloquent series of kinonyms and felonyms, which are based on frequently used "fashionable" loan-appealatives: China, Laksheri, Lakshmi, Starbaks, Dolar, Yevro, Baunti, Biuty, Best, Dota, Fleshka, Baks, Dolar, Yevro, Bumer, Kiber, Jaz, Joker, Jadai, Gyp, Eros, Nishtiak, Khaker, Khamer, Fest.

For a modern Ukrainian citizen, unlike a resident of the city of the 80s - early 90 s of the XX century, the name of the animal is less and less associated with a tradition. There are very ingenious owners who create unusual occasionalisms 
based on specific or borrowed lexical resources using modern word-formation models and the chance to meet very unusual nicknames grows with time: Barbatsutsa, Kokymota, Koshmi, Kusama, Kusymona, Murliashka, Murrkysia, Murchetta, Fronda Chudeta, Bandi, Dzhakuzia, Kotobubz, Kustiara, Limuryng. But most of the citizens are still guided by modern life realities, therefore the felinonyms and kinonyms Kryza, Voina, Arnold, Baks Banni, Balbes, Barbi, Beibik, Bekinhem, Betmen, Bumer, Burzhui, Heroin, Hilza, Dota, Mazhor, Mersedes, Khabibi, ChupaChups, Cyber, Jaz, Joker, Jadai, Jip, Eros, Nishtiak, Khaker are no longer surprising either in motivation or in the fact of the naming itself. Nevertheless, we should note that such nicknames are often based on borrowed nomens, while nomination precedents based on specific material among occasionalisms and direct transfers are decreasing.

Conclusions. The priority of the borrowed onyms and appellatives as the foundations of modern zoonyms suggests that modern nominative models in the field of urban zoonymy are taken not from the Ukrainian language, but most often from English and other European languages.

\section{Список використаних джерел:}

1. Стишов, О. А. (2005). Українська лексика кіния XX століття (с. 387). Київ: Пугач.

2. Вардзелашвили, Ж. А. (2011). Метафорические номинации в языковой картине мира. Тбилиси: Изд-во ТГПУ им. С.-С.Орбелиани.

3. Гусева, Е. В. (2002). Традиционные и частотные клички животных в языковой картине мира современного горожанина. Вестник Московского университета. Серия 9. Филология, (4), 91-104.

4. Harold, A. Herzog. (2014). Biology, culture, and the origins of pet-keeping. Animal Behavior and Cognition. DOl: 10.12966/abc.0. Вилучено з https://paws.wcu.edu/herzog/research.html

\section{«БЕРЕМЕННОСТЬ И «БЕСПЛОДИЕ» КАК ТРАДИЦИОННАЯ ОППОЗИЦИЯ В ФОЛЬКЛОРЕ ВОСТОЧНЫХ СЛАВЯН (НА ПРИМЕРЕ РУССКИХ ВОЛШЕБНЫХ СКАЗОК)}

Антоненко Наталия Павловна

канд. филол. наук, доцент кафредры украинознавства Киевский национальный университет строительства и архитектуры УКРАИНА

\section{І. Бесплодие и бездетность.}

Беременность, благополучное родоразрешение и материнство - одни из ключевых этапов сакральной истории личности, которая отражена в фольклоре восточных славян - в заговорах, казках, песнях (в том числе колыбельных), верованиях и традициях. Данные ситуации традиционно обладали высокой ценностью, множеством пожеланий для успеха и, конечно же, запретов. Например, нельзя перешагивать через коромысло (чтобы было правильное положение плода или будет болеть спина), нельзя пинать кошек 
и собак (у ребенка будет щетина, или будет «собачья старость»), нельзя во время вязания соединять нитки между собой узлами и т.д. [1].

Современные словаи определяют термин «бесплодие», как болезнь репродуктивной системы, которая выражается в отсутствии клинической беременности после 12 или более месяцев регулярной половой жизни без предохранения от беременности [9]. Явление бесплодия редко, но встречается и в фольклоре восточных славян - но речь идет не о двенадцати месяцах попыток зачатия, а о всей жизни в целом («В некотором царстве жил царь с иарицей, и не было у них детей» [2]). Неполная семья в фольклоре, когда в ней нет детей - это всегда величайшее горе. При этом упоминание этого фракта всегда неспроста - развитию основного действия будет предшествовать рассказ о том, как чудесным образом в семье все же появился ребенок. Сказка и заканчивается всегда созданием новой семьи [4].

Нарушения на уровне детородной функции расценивается фольклорной традицией как телесная аномалия. Бесплодие (отсутствие способности к деторождению) - состояние, наказания, несчастье, грех, позор [8] и помощи искали у различных трав, деревьев, людей. При бесплодии, женских болезнях, фригидности девушки обращались к рябине [11]. Бездетность в фольклоре рассматривается как страшное проклятие, серьёзная фризическая ущербность, а отношение к бездетным людям было сострадательное, как к инвалидам [12].

В русских волшебных сказках с неспособностью к рождению детей сталкиваются, прежде всего, представители высших сословий (цари, купцы): «В некотором царстве жил царь с царицей, и не было у них детей» [2]. Реже - представители хтонического мифомира: «Я с тобой триста лет живу, а у нас не было ни единого детища» [6], а также давно вышедшие из репродуктивного возраста люди: «Жил был старик и старуха. Детей у них не было» [6].

\section{II. Беременность.}

Процесс вынашивания ребёнка, родовой обряд и похоронный были очень похожи и были зеркально противопоставлены друг другу в фольклорной традиции восточных славян. Если в похоронах человека надо было правильно проводить на тот свет, то в родовом обряде надо было правильно принять человека с того света [7].

Ситуация беременности практически не характерна для русских волшебных сказок. Сказка начинается почти всегда тем, что герой достиг возраста инициации, а заканчивается свадьбой до рождения детей. Важно, что в сказке дети не умирают, а только рождаются - спираль жизни раскручивается в одну сторону.

Беременность в русских волшебных сказках считается актом вторжения потусторонних сил в жизнь человека, но преодолеть бесплодие можно при помощи сакральных ритуальных действий.

\section{III. «Таинство зачатия».}

Отсутствие детей в сказке, как и в фольклоре в целом, считается великим горем, поэтому происхождение ребенка всегда таинственно - дети в волшебной сказке появляются таким же волшебным способом. Если в сказке рождается ребенок, то он мгновенно наделяется «потусторонними» признаками или обладает сверхъестественными способностями. Т.В. Краюшкина выделяет три основных способа: чудесное зачатие, рукотворное тело и рождение из части тела. Чтобы женщина забеременела, в ее тело 
извне должен попасть некий предмет или субстанция (обладающие оплодотворяющей силой) [5], а также появление ребенка из яйца, которое символизирует собой модель мира.

- Чудесное зачатие путем сакрального приготовления пищи: "...жил царь с царищей, и не было у них детей. Сколько ни горевали, сколько знахарей ни звали - нет и нет у них детей. ... Повара рыбку вычистили, вымыли, сварили, а помои на двор выплеснули. Проходила мимо корова, помои полизала. Девка-чернавка положила рыбку на блюдо - отнести царице - да дорогой оторвала золотое перышко и попробовала. А царица рыбку съела. И все три понесли в один день, в один час: корова, девкачернавка и царица. И разрешились они в одно время тремя сыновьями» [2]. В фольклоре восточных славян рыба традиционно является символом плодородия, медиатором между мифомирами, символом беременности, а также рождения мальчика в русской волшебной сказке. При этом в фольклоре «...лещ и окунь снятся к рождению мальчика, плотва и щука - девочки» [3]. В данных контекстах реализованы синекдохические модели заговорных текстов (для рождения ребенка достаточно прикосновения даже к части сакрального).

- «Изготовление» ребенка из доступных материалов: снега, глины, теста, каши или дерева встречается во многих славянских сказках (Ивась, Жихарко, Лутонюшка, Снегурочка) - «Сделай колыбельку, я положу деревяшечку в колыбельку и буду качать...Встают утром - а в колыбельке сынок маленький» [2].

- Происхождение части от целого. "Один раз крошила баба на столе свеклу, торопилась и отрезала себе мизинчик... замотала пальчик в беленькую тряпочку и положила на теплую лежанку. Пальчик лежал-лежал, и вывелся из него маленький беленький мальчик» [10].

- Появление ребенка из яйца. «Сидит старик на яйцах двадцать одну неделю. Вывел старик двадцать сыновей» [172]. Появление человека из яйца, как модели мира, является проявлением мифопоэтических воззрений восточных славян и символики яйца как атрибута восстановления/рождения мира.

«Беременность» и «бесплодие» традиционно противопоставлены друг другу в русских волшебных сказках (по аналогии с оппозициями день/ночь, левый/правый, живой/мертвый). В отличие от славянской фольклорной традиции (где есть «промежуточные варианты» между жизнью и смертью потерчата, нерожденные дети, «в утробе убиенные»), в русских волшебных сказках встречается исключительно амбивалентные оппозиции живой/неживой. Русская волшебная сказка не знает абортов, выкидышей, замерших беременностей - жизнь либо дается ребенку, либо нет (что является отражением амбивалентности восприятия восточных славян). И если да, то ребенок в русской волшебной сказке появляется волшебным образом.

Бесплодие является одним из ключевых маркеров ирреальности в русских волшебных сказках. Беременность и рождение ребенка в таких случаях наступает благодаря повторному вторжению потусторонних сил в жизнь человека - дети появляются из яйца, из подручных средств или материалов, а также обладают необыкновенной внешностью и фантастическими способностями. 


\section{Список использованных источников:}

1. Диникеева, Ю. Г. (2014). Обряды, связанные с ожиданием ребенка русских Башкортостана: история и современность. Изъято из http://psytolerance.info/young.php?c=1375345650\&s= 1416167174.

2. Аникина, В. П. (сост.). (1986). Живая вода: сборник русских народных песен, сказок, пословии, загадок. Москва: Детская литература.

3. Кабакова, Г. И. (2001). Антропология женского тела в славянской традиции. Москва: Ладомир.

4. Корепова, К. Е. (1992). Русская волшебная сказка: антология. Москва: Высшая школа.

5. Краюшкина, Т. В. Чудесные дети и их появление на свет в русских народных волшебных сказках Сибири и дальнего востока. Вилучено 3 https://cyberleninka.ru/article/n/chudesnyedeti-i-ih-poyavlenie-na-svet-v-russkih-narodnyh-volshebnyh-skazkah-sibiri-i-dalnego-vostoka.

6. Народные сказки. Библиотека русской сказки в 10-ти томах (Т. 2.). (1992). Москва: Возрождение.

7. Панкеев, И. А. (2008). Обьчаи и обряды русского народа. От крестин до поминок. Москва.

8. Толстой, Н. И. (ред.). Славянские древности: этнолингвистический словарь: в 5 m.; Т. 1. (1995); Т. 2. (1999); Т. 3-4. (2009). Москва: Международные отношения.

9. Словарь Терминов ВРТ. Пересмотренный ИКМАРТ и ВОЗ словарь терминов ВРТ. (В. Корсак \& 3. Успенская, пер.). (2009). Изъято из https://www.who.int/reproductivehealth/publications/infertility/art_terminology2_ru.pdf.

10. Свиридова, Л. (сост.). (1989). У ключика у гремучего: Дальневосточный фольклор. Владивосток: Дальневост. кн. изд-во.

11. Чернышева, В. Г. (2015). Рябина. Изъято из https://myphs.jimdo.com/2015/01/09/pябина/.

12. Шангина, И. И. (2000). Русские дети и их игры. СПб.

\section{ВІДТВОРЕННЯ МОДАЛЬНОСТІ У ПРОМОВАХ ПОЛІТИЧНИХ ЛІДЕРІВ ВЕЛИКОЇ БРИТАНІЇ}

\section{Вдовиченко Ольга Олександрівна}

здобувач вищої освіти факультету лінгвістики та соціальних комунікацій Національний авіаційний університет

Науковий керівник: Сітко Алла Василівна канд. фріл. наук, доцент кафедри англійської фрілології і перекладу Національний авіаційний університет УКРАÏHA

Серед багатьох складних питань, які вивчає сучасне мовознавство, важливе місце займають проблеми перекладу. Як відомо, процес перекладу не $є$ простою заміною одиниць однієї мови одиницями іншої мови. Навпаки, це складний процес, який включає в себе цілу низку операцій [1].

Останніми десятиріччями у мовознавстві спостерігається перенесення акцентів у дослідницьких інтересах з вивчення мови як внутрішньої системи, в якій усе взаємопов'язане на вивчення мови-мовлення як діяльності або як дії 
[2]. Об'єктом дослідження мовознавчої науки уже довгий час виступає речення як багатоаспектна одиниця.

Модальність належить до найсуттєвіших характеристик речення i трактується як категорія, що виражає зв'язок висловлювання з реальною дійсністю. Однак, особливо цікавим $є$ відтворення дієслів, що виражають модальність на прикладі промов політичних лідерів Великої Британії. Проте, перед тим як досліджувати категорію модальність у політичному дискурсі, спочатку необхідно визначити, що означає саме поняття «політика». У більшості праць з політології сам термін «політика» трактується як «діяльність державних органів, об'єднань громадян та окремих осіб у сфері відносин між країнами, націями, великими групами людей, яка спрямована на розподіл влади та економічних ресурсів в країні, реалізацію та відстоювання своїх інтересів» [3]. Більшість політичних дій за своєю природою є мовленнєвими діями. Мова потрібна політикам для того, щоб інформувати, давати вказівки, приймати закони, акти, переконувати, тощо. А отже і застосування дієслів категорії модальності саме у політичному дискурсі має певні особливості.

Наведемо приклад з промови Джефрі Хау з застосуванням модального дієслова have to, яке, як було зазначено раніше позначає зумовлену обставинами повинність:

I have to say that I find Winston Churchill's perception more convincing, and more encouraging for the interests of our nation [4] - Я мушу сказати, що вважаю сприйняття Вінстона Черчиля більш переконливим і більш заохочуючим для інтересів нашої нації. [5].

У даному випадку суб'єктом здійснення повинності виступає сам суб'єкт висловлювання - британський державний діяч, член Консервативної партії Джефрі Хау. В українському перекладі застосовуємо відповідник «мусити».

Дієслово be to у поєднанні з інфінітивом основного дієслова виражає необхідність, що є результатом певного плану або ж домовленості.

But government's role is going to be to organize provision - like stakeholder pensions not fund it all through ever-higher taxes [4] - Але роль уряду повинна полягати у забезпеченні - як пенсії зацікавлених сторін не повинні фрінансуватися через підвищення податків [5].

Наведене вище висловлювання належить Тоні Блеру, прем'єр-міністру Англії. Висловлювань з таким відтінком повинності, необхідності у політичному дискурсі небагато, і всі вони безпосередньо мають відношення до інших суб'єктів, які, на думку суб'єкта висловлювання, зобов'язуються до чогось. Тобто суб'єкт висловлювання у політичній промові намагається уникнути розмов про свої обов'язки за попередньою домовленістю або певним планом. Що стосується перекладу на українську мову, то дане дієслово також слід перекладати як «бути повинним», «необхідно» в залежності від контексту оригінального твору позаяк саме враховуючи контекстну ситуацію, перекладач має можливість підібрати необхідну модель перекладу [6].

Трохи ширшого використання політичними лідерами Великої Британії набуло дієслово should, що має своєрідний відтінок поради. Наведемо приклади

з промов Тоні Блера та Ніка Клегга:

I should also say a final word of thanks to the Tory Party. Let's be honest, we'd never have done so well without them [4] - Я також повинен сказати останнє 
слово подяки партії Торі. Давайте будемо чесними, ми б ніколи не зробили так добре свою роботу без них [5].

Приклад з промови Ніка Клегга, британського політика, лідера Ліберальних демократів, колишнього віце-прем'єр-міністра Великої Британії:

We believe ministers should spend money as carefully as if they'd borrowed it from a friend [4] - Ми віримо, що міністри повинні розпоряджатися грошима так обережно, наче вони позичили їх у друга [5].

Необхідно зазначити, що дієслово, що виражає моральний обов'язок стосується не лише самого суб'єкта промови, що виражається займенником I, а й суб'єкта, що включає інших осіб (we). В українському перекладі знову ж помічаємо, що should перекладається як «повинний», «необхідний», але 3 відтінком певної настанови чи поради, оскільки існування у одиниці МО одного або декількох перекладних відповідників ще не означає, що ці відповідники будуть обов'язково використані під час перекладу. Як стверджує А.В. Сітко, у багатьох випадках умови використання мовної одиниці у контексті змушують перекладача відмовитись від використання мовної одиниці регулярного відповідника і знайти такий варіант перекладу, який би найбільш повно передав значення цієї одиниці у даному контексті [6].

Must вживається для вираження наказу, поради, заборони, обов'язку по відношенню до іншої людини або ж до самого себе, який необхідно обов'язково виконати. Також must може використовуватися для вираження вірогідності чогось або впевненості мовця у чомусь.

Наведемо приклад з промови Девіда Кемерона:

We must take everyone through with us on some of the difficult decisions we have made [4] - Ми повинні показати усім деякі з складних рішень, які ми прийняли [5].

Варто підкреслити, що саме у політичному дискурсі must має значення важливого обов'язку, який $є$ нагальним для виконання. В українській мові перекладом цього слова $€$ «повинний».

Варте уваги і модальне дієслово сап, що має значення фізичної здатності робити щось:

Making these savings will mean we can afford to spend money on things that really matter [4] - Заощадження будуть означати, що ми можемо витратити гроші на дійсно важливі речі [5].

Наведений приклад ще раз доводить, що у політичному дискурсі це модальне дієслово також означає фрізичну можливість, а тому i перекладається як «могти», «мати змогу».

Пропонуємо приклад з промови Королеви Єлизавети II:

This year, as governments search for new ways to tackle these important challenges, we as individuals can also play our part so that, in pursuing health and vitality for all, we bring hope to the world [4] - Цього року як уряд шукає нові шляхи вирішення цих важливих проблем, ми, як особистості, можемо відіграти свою роль у забезпеченні покращення здоров'я та життєздатності, ми є надією для цього світу [5].

Розглянемо приклад з промови Девіда Кемерона:

And a guide for that society, that those who can, should, and those who can't, we will always help [4] - I як провідник цієї нації, ми завжди допоможемо тим, хто може, кому слід і тим, хто не має фрізичної можливості [5]. 
$110 \bullet$ Problèmes et perspectives d'introduction de la recherche scientifique innovante $\bullet$ Volume 5

У наведеному вище прикладі Кемерон говорить про важливість забезпечення гідного рівня життя тим людям, які мають для цього обмежені ресурси та фрінансові можливості.

Приклад з промови Маргарет Тетчер 1986 року:

If they can't agree on the defence of our country, they can't agree on anything [4] - Якщо вони не можуть дійти згоди щодо захисту своєї країни, то вони не будуть здатними дійти згоди щодо будь-чого іншого [5].

Our opponents believe that all problems can be solved by state intervention [4] - Наші опоненти вірять, що всі проблеми можуть бути вирішені за допомогою державного втручання [5].

Ці приклади показують, що дієслово сап у значенні фрізичної можливості або вміння також може стосуватися власне політика, політика та його оточення, а також інших осіб / явищ.

Мау використовується у значенні ймовірності або дозволу, а в українській мові тау перекладається як «могти» і в цьому плані воно схоже на can, хоча в нього є свої відмінності. Так, дієслово тау має більший ступінь ймовірності ніж can і $є$ більш формальним. Приклад з промови Тоні Блера:

I may have been wrong [4] - Я можу помилятися [5].

Пропонуємо розглянути приклад з промови Маргарет Тетчер 1990 року:

I'm immensely grateful to the staff who supported me so well, and may I also say a word of thanks to all the people who sent so many letters, still arriving, and for all the flowers [4] - Я безмежно вдячна персоналу, який так мене підтримував, і я маю також сказати слово подяки тим людям, які надсилали мені листи, що досі приходять, і за всі квіти [5].

Наведені приклади демонструють, що дієслово тау має значення припущення, можливості здійснення будь-якої дії. Припущення може мати безпосереднє відношення до діяльності власне суб'єкта висловлювання (у сполученні з 'l'), спільної діяльності суб'єкта висловлювання та інших осіб (у сполученні з 'we') та взагалі інших осіб (у сполученні з іншими займенниками та іменниками).

Модальне дієслово would використовується для вираження волевиявлення мовця, його наміру або ж наполегливості. Часто would використовується як форма минулого часу від will або для вираження ввічливості. Як правило, дане дієслово виділяється інтонаційно та перекладається українською як «хотіти», «збиратися».

I would like to pay tribute to the outgoing prime minister for his long dedicated public service [4] - Я хотів би віддати належне колишньому прем'єр-міністру за

його довгу, віддану службу народу (Девід Кемерон) [5].

Приклад з промови Маргарет Тетчер 1985 року:

For my part, I would like to add my congratulations and thanks to all those who have taken the Chair at this Conference with skill and unfailing good humour [4]Зі свого боку, я хотіла б приєднатися до привітань і подякувати усім, хто брав участь у цій Конфреренції з вмінням та чудовим почуттям гумору [5].

Як бачимо, у наведених прикладах модальне дієслово would застосовується саме для вираження бажання, наміру. Помічаємо, що у політичному дискурсі would часто використовується саме у цьому значенні.

Таким чином, підбиваючи підсумки вище сказаного потрібно зазначити, що категорія модальності це складне і багатогранне поняття, котре потребує 
значної уваги. Оскільки форма мовних особливостей бере безпосередню участь у передачі їх сенсу, підтримуємо думку І.Струк та А.Сітко про те, що перекладач повинен насамперед прагнути до еквівалентності перекладу, а далі виходячи з принципу адекватності, тобто смислового добору сегментів вихідної мови прагнути до творчого та креативного пошуку вдалих прийомів i способів їх перекладу [7].

\section{Список використаних джерел:}

1. Сітко, А.В. (2007). Особливості перекладу англомовних інтерогативних конструкцій. Вісник Житомирського державного університету імені Івана Франка (33), 158-163.

2. Сітко, А.В. (2013). Структурні особливості англійських та українських інтерогативів, Нова філологія (58), 187-189.

3. Зеленский, В.В. (1996). Психология политики. Психологические и социальные идеи Карла Густава Юнга. Москва: Ювента.

4. British Political Speech. Retrieved from http://www.- britishpoliticalspeech.org/speecharchive.htm

5. Монтефіоре, С.С. (2017). Промови, що змінили світ. К. : КМ-БУКС.

6. Сітко, А.В. (2009). Роль контексту під час перекладу інтерогативних висловлювань. Мовні $і$ концептуальні картини світу. К. : Київський національний університет імені Тараса Шевченка, Вип. 26 (3), 143-148.

7. Сітко, А.В., Струк, І.В. (2016). Адекватність і еквівалентність у перекладі мовних особливостей. Sciences of Europe, Praha, Vol 1 (10), 122-126.

\section{ДОСВІД ВИКЛАДАННЯ РОСІЙСЬКОЇ МОВИ В АРАБОМОВНІЙ АУДИТОРІї}

Федоренко Валентина Степанівна старший викладач Харківський навчально-науковий інститут ДВНЗ «Університет банківської справи» УКPAÏHA

Методику викладання російської мови в іншомовній аудиторії відносять до самостійної педагогічної дисципліни. Вона спрямована на дослідження особливостей викладання російської мови як іноземної для тих, хто не володіє нею в якості рідної мови.

Вивченням методів викладання російської мови арабомовним студентам займалися багато видатних учених і внесли свій чималий внесок. Такі як: В.Г. Костомаров, Л.В. Щерба, О.Д. Митрофанова, А.Н. Щукін, Р.К. МиньярБєлоручева, О.В. Гуськова, А.Я. Хамза, Б. Алі, А.А. Абдуль-Ріда та інші.

Мета роботи полягає в тому, щоб виявити і систематизувати труднощі, які виникають у арабомовних студентів при вивченні російської мови як нерідної. Це можливо тільки на основі аналізу порівняльно-типологічних даних російської мови і арабської мови. Вирішальну роль в цьому процесі відводять соціолінгвістичним та лінгвокультурним особливостям російської мови і рідної мови студентів. 
Методиці викладання російської мови для іноземців характерна наявність своїх методів, які можна умовно розділити на теоретичні та практичні. До теоретичних методів належать: аналіз і синтез, моделювання, абстрагування, порівняння та інші. До практичних методів відносять наукове спостереження, узагальнення досвіду викладача, тестування, анкетування та інше.

Головна мета цих методів викладання російської мови в іншомовній аудиторії - виявлення основних проблем вивчення російської мови іноземцями та найпоширеніших помилок, які виникають у іноземців при вивченні російської мови з подальшим виробленням максимально ефективних методик викладання російської мови в якості іноземного, орієнтуючись на загальні цілі, які переслідують викладач і студенти.

Виходячи з вищесказаного, основним об'єктом дослідження методики викладання російської мови як іноземної $є$ безпосередньо сам процес навчання іноземців російської мови, а отриманий досвід в процесі навчання стане в подальшому хорошим результатом, як для викладача, так i для студента.

Найбільш популярним $€$ комунікативний метод. Його запропонував $€$. І. Пасів. Мета комунікативного методу - привити студентам уміння вирішувати комунікативні завдання, використовуючи при цьому іноземну мову (в даному випадку російську), можливість вільного спілкування з носіями мови. Ця методика характеризується поглибленим вивченням мовного спілкування, інтерпретуючи його як форму взаємодії людей за допомогою мови. Комунікативний метод розвивається в контексті значного впливу комунікативної лінгвістики, що обумовлює інтерпретацію в якості основних властивостей досліджуваної мови: системності, комунікативності, функціональності.

Як відомо, існує два види впливу рідної мови на вивчення іноземної: перенесення (транспозиція) і інтерференція (наслідки впливу однієї мови на іншу). При перенесенні (транспозиції) добре знайомі студенту явища рідної мови допомагають освоїти аналогічні явища, що вивчаються, тоді як при інтерференції ці явища заважають. Очевидно, що в силу того, що російська та арабська мови відносяться не тільки до різних мовних груп (слов'янської і семітської відповідно), а й сімей (індоєвропейської і афразійскої), явище інтерференції домінує при вивченні одного з цих мов носіями іншого. 


\section{ЕМОЦІЙНИЙ КОНЦЕПТ}

Вінійчук Анна Сергіївна

здобувач ступеня магістр факультету прикладної лінгвістики Національний Університет «Львівська політехніка»

Науковий керівник: Романишин Наталя Іванівна канд. фрілол. наук, доцент кафедри прикладної лінгвістики Національний Університет «Львівська політехніка»

УКРÄ̈HA

Кожна мова є унікальною, самобутньою та особливою. Оповідач, який хоче якось по-особливому проявити свої почуття, застосовує різноманітні лексичні одиниці, користується різними граматичними і фонетичними законами мови. За останні роки, в умовах глобалізації, розвитку інформаційних технологій, зростаючій ролі 3MІ та інших екстралінгвістичних чинників, використання метафор привертає до себе увагу все більшої кількості науковців, а відтак і зростає число публікацій, які висвітлюють проблему впливу метафор на людську свідомість та розглядають ї̈ як засоби регулювання настроїв у суспільстві, прийомом маніпуляції суспільною думкою.

Найпростіші мовні ситуації, що вимагають мовної поведінки, яка відповідає певній комунікативній стратегії можуть призвести до парадоксів мовного спілкування, тобто людина постійно буде відчувати нездатність до мовної взаємодії з іншими членами цього ж мовного осередку. I справа не в незнанні мови, а в невмінні коректно нею користуватися, тобто в невмінні "розкрити" себе в тій або іншій мовній ситуації [5].

Метафора завжди привертала увагу багатьох вчених та фрілософрів. Науковим переворотом стала когнітивна теорія метафори, Джорджа Лакоффра та Марка Джонсона. Вона з'явилася у другій половині XX ст. Було доведено, метафора належить не лише до сфрери слів, а й до сфери мислення та дії. Згідно цієї теорії, тіло людини - це канал взаємодії з навколишнім світом, а значить всі концепти будуються навколо чуттєвого сприйняття дійсності.

Метафори - одне з найбільш продуктивних засобів фрормування вторинних найменувань у створенні мовної картини світу. Метафоричні позначення, «вплітаючись» у концептуальну систему відображення світу, «забарвлюють» її у відповідності з національно-культурними традиціями і самої здатністю мови називати невидимий світ тим чи іншим способом [3]. Тим самим мовна картина світу обумовлена явищем - як внутрішньомовним і міжмовним, але не зводиться до нього, так як являє собою той продукт розумової діяльності, який вносить семантичне значення в дійсність, самобутнє для будь-якої мови. Вона має великий вплив на світогляд мовця та має важливе значення у процесі мислення. Вона, водночас і засіб пізнання дійсності і результат когнітивної діяльності [4].

Проблема мовної картини світу найтіснішим чином пов'язана з проблемою метафори як одним із способів ії створення. Найбільш фрундаментальні культурні цінності узгоджені 3 метафоричною структурою основних понять даної культури. 
Кожна країна, нація має свою мову, а отже і свій світогляд та розуміння будови світу. Багато науковців виділяють мовну і концептуальну картини світу [1]. Концептуальна картина світу (ККС) - це глобальний образ світу у вигляді системи уявлень. Це результат пізнання навколишнього світу людиною. Концепти поєднують у собі знання про реалії у вигляді абстрактних понять. Якщо порівнювати, концептуальна картина світу масштабніша. На відміну від мовної, яка характерна для кожної нації, ККС не залежить від того, з якою країни людина. Проте у різних людей вона може бути різною. Це залежить від епохи, вікової категорії, обізнаності.

Концепт - центральний термін у мовній картині світу. Проте він не має однозначного значення. Було проведено багато теоретичних розробок навколо концепту. В основному його широке використання пов'язане 3 розширенням предметної області лінгвістичної семантики.

Людина, здобуваючи нові знання, перетворює їх у концепти, які, у свою чергу, уже створюють концептуальну систему. Вона ж формується людиною безупинно. 3 чого можна зробити висновок, що однією з ознак концепту $\epsilon$ здатність до змін.

На відміну від конкретного значення слова, концепт - це сукупність усіх значень того ж слова.

Вивчення емоційних концептів - актуальна тема у лінгвістиці. Навіть звичайні стандартні емоції у різних культурах мають своєрідні ознаки, а їх вербалізація допомагає зрозуміти, яка між ними різниця. Саме тому, на сьогоднішній день ми маємо безліч наукових праць, де конкретно описується будь-який з емоційних концептів (страх, любов, сум та інші).

Емоційний концепт розуміється як «етично, культурно обумовлене, складне структурно-смислове, як правило, лексично і фразеологічно вербалізоване утворення, що базується на понятійній основі, включає окрім поняття, образ, оцінку і культурну цінність, і що функціонально заміщає людині в процесі рефлексії та комунікації предмети одного порядку ..., що викликають упереджене відношення до них людини» [2].

Емоція - це психологічний стан людини, ії̈ ставлення до навколишнього середовища та самої себе. У наш час сфера емоцій $є$ об'єктом дослідження у багатьох галузях: психології, лінгвістики, філософрії та інших, а швидше ії вивчали психологи і аж ніяк не лінгвісти. Лише пізніше виникла нова наука емотіологія, яка об'єднує здобутки когнітивної лінгвістики та психології. На основі отриманих в інших галузях знань про емоції, створюється лінгвістична концепція емоцій. Саме тому обґрунтованим $€$ те, що етимологію ще називають наукою про вербалізацію емоцій.

Якщо пізнавальні процеси виражаються у відчуттях, поняттях чи думках, то емоції - це суб'єктивне відношення до навколишньої дійсності. Щось людині подобається, щось викликає відразу, а щось - залишає байдужою. Таким чином, можна зробити висновок, що емоції - це певний клас суб'єктивних психологічних станів. Їх можна розділити на два типи: позитивні та негативні емоції.

Позитивні емоції - це похвальна думка про щось. Вченими доведено, що такі емоції розширюють кровоносні судини, підвищують температуру тіла та розумову працездатність. Іншими словами, вони спонукають до діяльності. До позитивних емоцій відносять щастя, радість, любов, ніжність та багато інших. 
Негативні емоції - повна протилежність. Вони виникають при невдачах, викликають психологічну дезорієнтацію та вимагають зміну ситуації. I хоч негативні емоції мають величезний вплив на наше здоров'я, вони теж важливі. Вони допомагають людині адаптуватися до життя. До негативних емоцій відносять страх, тугу, ненависть, ревнощі та інші.

Проблема вивчення емоцій у наш час дуже актуальна тема. Вона цікавила і продовжує цікавити багатьох науковців. Зокрема, регулярно визначається роль емоцій та їх сприймання в процесі спілкування. Минулі дослідження доводять те, що ці моменти основні для щасливого існування.

ЛЮБОВ / КОХАННЯ - це однозначно тільки позитивна емоція. Це почуття глибокої прихильності до когось або чогось. В українській поезії XX ст. використовували метафору для осмислення різних почуттів, але найчастіше в творах опиняються почуття любові та кохання. Це близькі, але не однакові почуття. Близькість їх виявляється тільки в ознаці «почуття глибокої сердечної прихильності до особи іншої статі», проте і в цьому випадку вони відрізняються між собою.

Поняття любові та кохання в творах українських письменників постійно опоетизовувались, але часто змінними були їх шляхи передачі у віршованому творі. С. Павличко казав, що любовний вірш завжди належав до найбільш нерозвинутих в українській традиції.

В епоху модернізму змальовування цього почуття змінилось, втратилась платонічність і з'явився еротизм та сексуальність. Наприклад, у текстах В. Пачовського, передача емоцій літературного героя надмірно сексуальна, 3 деталями фізіологічного змісту. Трапляються в літературі XX ст. й випадки переосмислення почуттів та емоцій як вітру, бурі, хуртовини або стихії загалом, показуючи концепт ЛюБОВ - СТИХІЯ: «й горітиме в віках, стихії смутку і любові».

У своїх творах М. Вороний зображував почуття любові здебільшого як щось платонічне, звідси концепт ЛЮБОВ - ТАЛІСМАН: «урочий подарунок», «любов була єдиним талісманом, а талісман ще звався - оберіг».

Наприкінці XX століття передача любові та кохання у творах великої кількості письменників набула природності, повсякденності. Сталася неначе заміна поняття, замість почуття словами любов та кохання стали позначати ЛЮБОВ - СТАТЕВИЙ АКТ: «В пасоці кохань, рентґенознімки ночі простирадла...».

Головними віхами під час побудови метафор впродовж $\mathrm{XX}$ ст. були концептуальні схеми знань когнітивної карти рослини, тому тут можна спиратися на концепт ЛЮБОВ - РОСЛИНА. Ось, наприклад, О. Олесь, немов би констатуючи, писав: «в душі моїй - квітки, квітки любові розцвітають», а М. Вінграновський відображає почуття еротично, 3 деякими фізіологічними подробицями: «зацвіли твої пальці першим цвітом любові».

Створення метафор любові і кохання в українській поезії XX ст. відбувалося в основному за одними й тими ж схемами. Так, і любов, і кохання переважно передавали за допомогою термінів концептосфери природа, залучаючи донорські зони рослини та вогонь. На основі базової моделі рослини $\rightarrow$ любов / кохання окремі митці створювали новітні поетичні форми за допомогою методів синопсії: «любов - солома, і сірник не згас, від мене йдеш, немов душа од тіла, // так легко підіймаєшся угору, // а я в стіні забутого собору // любові нашої лежу зітліла». 
Троянда та мак були квітами богині кохання. Поети XX ст. ці квіти теж аналогізували з високими почуттями любові та кохання: «а у мене в серці рожі // і сміються солов'ї, вечоровими фіолетами // зацвітає на серці мак». 3 рослинами відбувалась асоціація любові об'єкту закоханості, а з вогнем зв'язували вияв любові в суспільстві, тому ще один зв'язок ЛЮБОВ - ВОГОНЬ «і всю журбу, і віковічний спокій огонь любові встане й спопелить» [6].

Даним фактом можна пояснити застосування мовних символів донорської зони вогонь при створенні любовної метафори. Асоціація вогонь $\rightarrow$ любов $\epsilon$ смисловою міфологічною метафорою, яку виділяв ще О. О. Потебня. Із допоміжної сфери вогонь на приймаючу сферу любові письменники накладали різноманітні значення, про що говорять мовні символи розпалювати, горіти, полум'я і жар: «у серці розпалю любов, // любов до світла, до життя», «моя любов горітиме яркіш // на всі віки, на тисячі століть», «так я відкрив, що полум'я любові, // плачі і радощі в моїй душі - // все з одності землі моєї й крові», «і як у серці поєднати // розлуки лід, любови жар!».

Пожежа та полум'я - синоніми до слова вогонь, тому багато авторів використовували саме його. Такий мовний символ частіше застосовувався для утворення метафор зі словом кохання, тому давайте розглянемо схожий концепт КОХАННЯ - ПОЖЕЖА: «Моє кохання - // пожар душі, і кожний згук // мого крилатого признання», «Отак і ми без каяття, // Без сумніву й вагання // Кидаємо своє життя // У полум'я кохання».

І у греків і у римлян птахом богині кохання $€$ голуб, тому паралель КОХАННЯ - ГОЛУБ також повністю відповідає традиціям: свою любов, голубку швидкокрилу, // давно я випустив на білий світ, // аби вона будила сонце в морі, // воркуючи ім'я лиш Беатріче.

Прекрасне почуття любові ототожнювали 3 медом, використовуючи концепт ЛЮБОВ - МЕД та передаючи за допомогою метафор солодкість цього почуття: «мед любові випивай // 3 золотої чари, прозорий мед любові».

Коли поети використовували концепт ЛЮБОВ - ВИНО, вони пов'язували кохання з утратою здатності розсудливо й критично розцінювати реальність під дією цього почуття. Із вином українські поети здебільшого зв'язували кохання, пишучи: кохання золоте вино, вином кохання напоєні наші очі. Стан закоханості аналогізували зі сп'янінням: «солов"ї за твоєю хатою // виливають кохання хміль, і ми хмільні не од вина - // ми від кохання п'яні».

Розглянувши різні репрезентації концепту ЛЮБОВ, можна зробити висновок, що для людини це почуття дуже глибоке та чуттєве, можливо, найвеличніше із усіх почуттів. Аналіз багатьох поезій XX ст. показує ставлення до цього почуття. Ця тема далекосяжна, оскільки не досліджено багато відношень з цим концептом.

\section{Список використаних джерел:}

1. Азарова, О. А. \& Кудряшов, И. А. (2015). Метафора и ее персуазивные эффекты в публицистическом тексте. В мире научных открытий, (5), 2008-2022.

2. Лакофф, Дж. (2004). Метаффори, якими ми живемо (А. Н. Баранова, пер. з англ.). Москва: Едиториал УРСС.

3. Пентилюк, М. І., Нікітіна, А. В. \& Горошкіна, О.М. (2004). Концепція когнітивної методики навчання української мови. Диво слово, (8), 5-9.

4. Голубовська, І.О. (2016). Вступ до мовознавства. Київ: Академія. 
5. Красавский, Н. А. (2001). Эмоциональные концепты в немецкой и русской лингвокультурах: Монография. Волгоград: Перемена.

6. Воркачев, С. Г. (2005). Лингвоконцептология и межкультурная коммуникация: истоки и цели. Филологические науки. (4), 76 - 81.

\section{ІЗОМОРФНІ ТА АЛОМОРФНІ РИСИ СКЛАДНИХ РЕЧЕНЬ В АНГЛІЙСЬКІЙ Й УКРАЇНСЬКІЙ МОВАХ, ТА ОСОБЛИВОСТІ ПЕРЕКЛАДУ СКЛАДНИХ РЕЧЕНЬ}

здобувач вищої освіти факультету лінгвістики та соціальних комунікацій Національний авіаційний університет

Науковий керівник: Сітко А. В. кандидат філологічних наук, доцент кафедри англійської філології і перекладу Національний авіаційний університет УKPAÏHA

Вживання складних речень є досить поширеним як в усному так і писемному мовленні. Тому для чіткого формулювання та вираження власних думок, питань та повідомлень необхідно знати та розуміти особливості будови і перекладу речень цього виду.

Мета мого дослідження: встановити ізоморфні та аломорфні риси складного речення в українській та англійській мовах, а також особливості перекладу складних речень.

Складним називають реченням, утворене з двох чи кількох простих речень, що об'єднані в одне ціле за змістом та інтонацією [1]. Проаналізувавши наукову літературу, можна виявити, що у англійській мові виділяють два типи складних речень (складносурядне та складнопідрядне), а в українській аж чотири (складносурядне, складносурядне, безсполучникове та мішаного типу). Складносурядним реченням англійської та української мов характерним є те, що його частини виражають такі смислові відношення: одночасність, послідовність та протиставлення дій, явищ чи станів, а також причиннонаслідкові зв'язки. Щодо складнопідрядних речень, варто відмітити, що як і в англійській так і українській мовах, прості речення можуть сполучатися за допомогою сполучників підрядності та сполучних слів. Проте безсполучниковий спосіб зв'язку у складнопідрядних реченнях $€$ характерним лише для англійської мови. В основу класифікації складнопідрядних речень покладено структурно-семантичний принцип, який полягає в тому, що складне речення розглядається як єдине ціле із взаємозв'язком складових частин головної і підрядної [1]. В українській мові немає такого поняття, як підряднепідмет, підрядне-присудок чи підрядне-додаток. Ізоморфними є лише такі види складнопідрядного речення як означальне та обставинне. 3 підрядного обставинного в англійській та українській мові виділяють: підрядне часу, місця, 
способу дії, причини, мети, порівняння та наслідку. Проте в англійській мові виокремлений ще один тип - підрядне обставинне поступку, а в українській з'ясувальне речення. Така підрядна обставинна частина поступку вказує на існування певної перепони, не дивлячись на яку відбувається дія, описана в головній частині. Щодо підрядного з'ясувального, його функцією $є$ уточнення зміст присудка в головній частині. Також аломорфною рисою $є$ вживання розділових знаків у складних реченнях. Для досягнення комунікативної завершеності складного речення в писемному мовленні, в українській мові використовують такі розділові знаки: кома, тире, крапка з комою, двокрапка. В то й ж час в англійській мові це лише кома або крапка з комою.

Для досконалого перекладу складних речень та чіткої передачі інформації, необхідно знати особливості не тільки їх будови, а й власне самого процесу перекладу. Так як в англійському мовленні підрядний тип зв'язку значно поширеніший аніж сурядний, то при перекладі з англійської підрядність часто замінюється сурядністю. Для перекладу складних речень застосовують деякі перекладацькі трансформації. Зокрема об'єднання. В цьому випадку самостійні речення об'єднуються в одне складне, проте загальний зміст залишається незмінним. Наступною трансформацією, яку застосовують при перекладі речень такого типу $є$ членування. В такому випадку одне складне речення перетворюється на декілька простіших. Цю трансформацію застосовують оскільки така велика кількість інформації в одному реченні не відповідає нормам української мови. Якщо прості речення ускладнені різними конструкціями, що часто спостерігається в англійській мові, то при перекладі на українську їх переважно замінюють складними реченнями. Через велику кількість підрядних речень в англійській мові, в українській їх часто перетворюють на прості, але ускладнені дієприкметниковим чи дієприслівниковим зворотом.

Отже, для чіткого вираження повідомлення, думок та досконалого перекладу необхідно знати та розуміти особливості складних речень. Звичайно є чимало ізоморфних рис таких речень української та англійської мов, проте необхідно також звернути увагу на їх відмінності, зокрема у будові та класифрікації. Аби досягти досконалості у перекладі речень такого типу, слід використовувати згадані вище перекладацькі трансформації та способи перекладу.

\section{Список використаних джерел:}

1. Радишевська, М. І. (2008). Новий довідник: Українська мова. Українська література. Київ: Казка.

2. Бархударов, Л. С. \& Штелинг, Д. А. (1973). Грамматика английского языка. Москва: Изд-во литературы на иностранных языках.

3. Верба, Л. Г. (2002). Граматика сучасної анелійської мови: Довідник. Київ: Логос. 


\title{
К ПОНЯТИЮ ЭКВИВАЛЕНТНОСТИ И АДЕКВАТНОСТИ КАК ИНДИКАТОРАХ КАЧЕСТВА ПЕРЕВОДА
}

\author{
Варлавина Мария Игоревна \\ Северо-Кавказский Федеральный Университет \\ РОССИЙСКАЯ ФЕДЕРАЦИЯ
}

Долгое время среди ученых в области теории и практики перевода превалировало мнение о том, что оценить качество перевода можно, лишь сравнив текст оригинальный и текст его перевода. Критерием оценивания была категория эквивалентности. Теория эквивалентности была разработана рядом ученых, например, Я. И. Рецкером, В. С. Виноградовым, В. Н. Комиссаровым. Тем не менее часто происходит замена понятия «эквивалентность» термином «адекватность». Стоит отметить, что категории эквивалентности и адекватности - это разные вещи. Как утверждал А. В. Федоров, адекватность - это «исчерпывающая точность в передаче смыслового содержания подлинника и полноценное функциональностилистическое соответствие ему» [3]. В. С. Виноградов утверждал: «Под эквивалентностью в теории перевода следует понимать сохранение относительного равенства содержательной, смысловой, семантической, стилистической и функциинально-коммуникативной информации, содержащейся в оригинале и переводе» [2]. Таким образом, понятие «адекватный перевод» имеет более широкий смысл, чем «эквивалентность» и, по существу, означает качественный перевод, обеспечивающий межъязыковую коммуникацию в определенных условиях.

На западе специалисты переводоведения иначе смотрят на определение данного термина. Многие специалисты утверждают, что «хороший» перевод это не только относится к адекватности, но и к его эквивалентности. Так. У. Уиллс в своем труде «The science of translation» утверждает, что эквивалентность не может полноценно изучаться теоретиками [5]. М. Бэйкер разделяет эквивалентность на уровне лексем, фразеологизмов, а также эквивалентность грамматическую и текстовую [4]. Также существует мнение о том, что эквивалентность субъективна, и она соотносима лишь с самим переводчиком.

Мы считаем, что буквальности в переводе необходимо избегать, поэтому незначительные отклонения от текста оригинала могут иметь место. На наш взгляд, смысловые ошибки, не препятствующие пониманию текста оригинала, не являются критерием для оценки качества перевода. Внимание стоит уделить ошибкам, ведущим к изменению смысла оригинала, к примеру, неадекватным переводам реалий, пропускам целых фраз, орфографрическим и пунктуационным ошибкам. Значимость ошибки зависит от цели самого текста. Также внимание стоит уделять адресату художественного текста, учитывать его ожидания и потребности. Однако И. В. Арнольд утверждает, что «подготовленность читателя, отнюдь не исчерпывается знанием языка, на котором написано произведение» и указывает на то, что овладение языком должно идти параллельно с восприятием художественной литературы [1]. 
Здесь стоит отметить значимость работы переводчика, благодаря которой читатель без знания языка оригинала может прочесть то или иное художественное произведение. Очевидно, что перевод произведения должен оказывать такое же влияние на читателя, как и текст оригинала.

\title{
Список используемых источников:
}

1. Арнольд, И. В. (1999). Семантика. Стилистика. Интертекстуальность: сборник статей. Бухаркин, П. Е. (науч. ред.). Санкт-Петербург: Санкт-Петербургский государственный университет.

2. Виноградов, В. С. (2007). Перевод. Романские языки: общие и лексические вопросы (4-е изд.) Москва: Издательство КДУ.

3. Федоров, А. В. (2003). Основы общей теории перевода (лингвистические проблемы). Москва: ФИЛОЛОГИЯ ТРИ.

4. Baker, M. (1992). In other words. A coursebook on translation. Routledge-London-New York.

5. Wills, W. (1982). The Science of Translation. Problems and Methods. Gunter Narr Verlag Tubingen.

\section{КЛАСИФІКАЦІЙНІ ОЗНАКИ ЛІНГВОКУЛЬТУРНОГО КОНЦЕПТУ ЛЮДИНА}

\begin{abstract}
Гарбера Ірина Володимирівна
кандидат філологічних наук, доцент кафедри загального та прикладного мовознавства і слов'янської фрілології Донецького національного університету імені Василя Стуса

УКРÄ̈̈A
\end{abstract}

Концепт - це базова оперативна одиниця мислення людини, продукт індивідуальної й колективної свідомості та пам'яті, що відображає (віддзеркалює) предмет або явище дійсності у вигляді певних ментальних образів, несучи про них усю добуту шляхом пізнавальної діяльності інформацію, обов'язково виражаючи специфічну етнокультурну маркованість, емотивність, оцінність і набуваючи вербального вигляду (за допомогою лексем, фразеологізмів, висловів тощо) [1]. Концепт людина є ключовим і фундаментальним у лінгвоконцептосфері носіїв української мови й культури, a - $з$ огляду на антропоцентризм сучасних мовознавчих досліджень - постає актуальним предметом вивчення. Структура концепту людина включає 4 складники: поняттєвий, значеннєвий, образний і оцінний. Таким чином, людина - природно-соціальна істота, що має свідомість і мову, здатна мислити, продуктивно працювати, еволюціонувати, створюючи власну історію та національну культуру [1]. Серед класифікаційних ознак лінгвокультурного концепту людина можна виокремити: 1) комплексність побутування (концепт це умовна ментальна одиниця, спрямована на комплексне вивчення мови (сфера уречевлення концепту), свідомості (сфера перебування концепту) та культури (детермінує концепт)); 2) ментальна природа (концепт існує у 
свідомості, де й відбувається безпосередня взаємодія мови та культури); 3) ціннісність («центр» концепту, оскільки останній слугує дослідженню культури, основу якої становить ціннісний принцип); 4) умовність і розмитість (концепт групується навколо певної «сильної» (ціннісно акцентованої) точки свідомості, від якої розходяться асоціативні вектори; найактуальніші для носіїв мови асоціації утворюють ядро концепту, менш значущі - периферію; чітких меж концепт не має; мовна одиниця, якою актуалізовано центральну точку концепту, слугує іменем концепту - в нашому випадку це лексема «людина»); 5) мінливість (концепт характеризується змінністю інтенсивності оцінки, образного й поняттєвого (фактуального) складників); 6) обмеженість свідомістю носія (концепт існує в індивідуальній і колективній свідомості (індивідуальні концепти багатші та різноманітніші, ніж будь-які колективні - від мікрогрупових до загальнолюдських - оскільки колективна свідомість та колективний досвід $є$ умовною похідною від свідомості та досвіду окремих індивідів, які утворюють колектив; цю похідну фрормовано через редукції всього унікального в персональному досвіді та підсумовування збігів); концепт людина є, безумовно, колективним); 7) компонентність (у складі будь-якого концепту виділяють ціннісний, образний (образно-перцептивний та образнометафоричний), поняттєвий (фактуальний) компоненти тощо; фактуальний компонент зберігається у свідомості у вербальній фрормі, образний $є$ невербальним і може лише описуватися й інтерпретуватися - наприклад, за допомогою кодів культури); 8) поліапельованість (до того самого концепту можна апелювати за допомогою мовних одиниць різних рівнів: лексем, фразеологізмів, вільних словосполучень, речень; у різних комунікативних контекстах та сама одиниця здатна бути «входом» у різні концепти); 9) багатовимірність (відкрита та необмежена); 10) методологічна відкритість і полікласифрікованість (концепти можуть класифікуватися за тематикою, за носіями, за типами дискурсу, за типами трансльованості) [2].

\section{Список використаних джерел:}

1. Гарбера, І. Мовноареальне поле концепту людина: фрразеокодовий рівень $i$ лінгвокомп'ютерне моделювання. (2018). (Ж.В. Краснобаєвої-Чорної ред.). Вінниця: ТОВ «Нілан-ЛТД».

2. Карасик, В., Слышкин, Г. (2005). Базовые характеристики лингвокультурных концептов. Антология концептов / ( В. Карасика, И. Стернина ред.), (1). Волгоград: Парадигма, 1013. 


\title{
МОВА І МОВЛЕННЯ В УКРАЇНСЬКИХ ПРИСЛІВ'ЯХ І ПРИКАЗКАХ
}

\author{
Зубець Наталя Олександрівна \\ канд. фрілол. наук, доцент, доцент кафедри української мови \\ Запорізький національний університет \\ УKPAÏHA
}

Прислів'я і приказки (паремії) є різновидом багатої колективної творчості українського народу, у якому втілюється глибина його думки та сила переконання. Цей жанр почав формуватися дуже давно, у часи Київської Русі він уже був високорозвиненим, виконував комунікативну і директивну функції. У процесі історичного розвитку паремії змінювали свою форму, розширювали семантику і ставали кодексом неписаних законів моралі та поведінки для нових поколінь, доповнюючи мовну і концептуальну картини світу українців.

Паремійний корпус української мови залишається невичерпним джерелом для наукових досліджень завдяки унікальній логіко-семіотичній, структурній і образній організації складників. Сучасні пареміологи Ж. Колоїз, З. Коцюба, Ю. Прадід, О. Селіванова, Д. Ужченко та ін. поглиблюють наукові знання, започатковані О. Потебнею, М. Сумцовим, І. Франком, про прислів'я і приказки як лінгвальні знаки мови, розглядаючи їх у когнітивному, семіотичному, текстовому, дискурсивному аспектах. Вітчизняна пареміографрія збагатилася тлумачним словником нового типу «Комунікативний кодекс українців у пареміях» [1]. Його автори Т. Космеда та Т. Осіпова репрезентували українські паремії у фокусі основних законів комунікації (виокремлено 18), кожен із яких розкриває сутність основних параметрів, що регулюють комунікативний процес (закономірності, тенденції, ситуації).

Прагматика паремій націлює мовців на використання їх як готових мовних елементів у процесі спілкування. Ми підтримуємо думку дослідників, котрі відносять паремії до згорнутих текстів, яким властиві цілісність, зв'язність, дискретність, антропоцентричність. Під прислів'ями і приказками розуміємо аксіологійно-значущі судження, що в лаконічній, образній формі містять національно орієнтовані узагальнення об'єктивної дійсності, константи народного мислення.

Прислів'я і приказки про мову та мовлення, які вважаються найважливішими категоріями духовно-етичної сфери життя, утворюють достатньо струнку систему поглядів на ці явища. Отже, розглянемо паремії цієї групи з точки зору реалізації семантичного критерію і прагматики. Джерелом дослідження стали збірки «Народ скаже - як зав'яже» [3], «Українські прислів'я та приказки» [4], упорядковані відповідно Н. Шумадою та С. Мишаничем М. Пазяком, звідки було вибрано понад 400 паремій, що представляють опозицію «мова - мовлення», які підлягали контекстуальному аналізу 3 подальшою інтерпретацією.

Як наукова категорія мова являє собою «природну систему комунікативних знаків і правила їх функціонування» [2]. Ї̈̈ часто ототожнюють з мовленням «конкретно застосована мова; засоби спілкування в їх реалізації» [2]. 
Головним складником мовної системи є слово. Це засвідчує і народний досвід: Слова дружаться - мова твориться [3], Слово до слова - зложиться мова [4]. Зафріксовано такі варіанти прислів"їв: «Рідна мова - не полова» [3], «Слово не полова» [4].

Загалом у зафріксованих пареміях компонент «мова» вживається рідко, натомість найчастіше «слово (словечко, слівце)» - як мовна діяльність, «річ», «розмова», «бесіда», «звістка», «приказка», «вимівка», «говірка» - лексеми з семою 'говоріння' («Розумну річ приємно й слухати» [3], «Де багато бесіди, там мало користі» [4], «Ні здумати, ні згадати, ні в приказці кому сказати, що він говорив» [4], «Найліпша вимівка - всьому винна дівка» [4]), а ще контекстуальними синонімами виступають слова «гук», «пісня», «галу-балу» («На кожен гук не одгукнешся» [4], «Таку пісню заспівала, що й на вуха не налазить» [4], «Галу-балу, а кіт з'їв сало» [4]). Використання емоційно забарвлених, стилістично маркованих, діалектних слів у цьому випадку свідчить про існування наївної картини світу, створеної за допомогою прислів"їв і приказок.

Урахування комунікативних ситуацій, прагматичних можливостей, національних особливостей паремій про мову і мовлення дало нам можливість визначити провідні риси ключових лексем, що допомагає раціонально використовувати їх у процесі спілкування.

І. Давність мови (слова).

Найточніша вказівка на вік слова міститься у притчі з Євангелія, яка починається словами «Спочатку було Слово...». Хоч у прислів"ї «Слово старше, ніж гроші» вік слова визначається з пізніших часів, розуміємо, що мова, слово з'явилися дуже давно. Народний досвід стверджує, що довше можна обійтися без грошей, ніж без мови, яка вагоміша, цінніша, благородніша.

II. Сила мови (слова).

Це правило фрормулюємо, беручи до уваги такі прислів'я та приказки, як-от: «Впік мене тим словом, не треба й вогню» [3], «Коня керують уздами, а чоловіка - словами» [3], «Ліпше переконувати словами, як кулаками» [3], «Шабля ранить тіло, а слово - душу» [4], «Слово може врятувати людину, а може і вбити» [4], «Бджола жалить жалом, а чоловік - словом» [4] та ін. У наведених пареміях проводиться думка про те, що необачне, грубе слово може призвести людину до відчаю, морально її вбити, принизити. Стилістична побудова таких одиниць урізноманітнена паралелізмами.

III. Ціна слова (мови).

Вважається, що найдорожче добро в народу - його мова. Це стверджують прислів'я: «Слово дорожче золота» [3], «Добре слово краще, ніж готові гроші» [4]. Людина, наділена такими чеснотами, як правдивість, порядність, гідність, справедливість, відповідальність, завжди вважалася високоморальною. Це відображено в таких прикладах: «Будь господарем своєму слову» [3], «Мовивши слово, треба бути йому паном» [3], «На його слові можна мур мурувати» [3], «Добре слово краще, ніж готові гроші» [4], , «Хоч чоловік і вбогий, та слово в нього чисте» [4] та ін. Отже, мова, слово становлять велику цінність для окремих носіїв і всього народу. 
У витворах і надбаннях трудового народу виявляються спрощені погляди, в тому числі - на мову (у порівнянні з науковими): «Мова - не полова...», «Слово - не сажа.». У сучасному технізованому, комп'ютеризованому, урбанізованому світі не всім відомі слова «полова», «сажа», ужиті в наведених прикладах у переносному значенні. Оригінальність таких паремій виявляється в тому, що в їхній стилістичній побудові міститься заперечення.

IV. Народна характеристика слова (мови).

У складі багатьох прислів"їв і приказок для позитивної характеристики слова (мови) ужито прикметники в переносному значенні, наприклад: добре, красиве, красне, лагідне, ласкаве, привітливе, солодке, тепле, щире; однак наявні також дуже сильні, хоч і негативні характеристики, наприклад: гостре, грубе, жорстоке, зле, лихе, масне, пусте, холодне.

Висновки. У пареміях український народ відобразив своє розуміння мови $\mathrm{i}$ мовлення, доповнивши мовну картину світу своїм баченням і сприйняттям цих найважливіших категорій духовно-етичної сфери життя, які сьогодні готові до оновлення. Виокремлені на основі національної своєрідності і прагматики риси ключових лексем для їх раціонального використання в комунікації надалі може деталізуватися, а перелік розширюватися.

\section{Список використаних джерел:}

1. Космеда, Т. А. \& Осіпова, Т. Ф. (2010). Комунікативний кодекс українців у пареміях: тлумачний словник нового типу. Дрогобич: Коло.

2. Шумада, Н. (упор.) (1971). Народ скаже - як зав'яже (українські народні прислів'я, приказки, загадки). Київ: Веселка.

3. Мишанич, С. \& Пазяк, М. (упор.) (1984). Українські прислів'я та приказки. Київ: Дніпро.

4. Кочерган, М. (2003). Загальне мовознавство: підручник. Київ: ВЦ «Академія». 


\section{LES NOTES}




\section{$\Lambda \mathrm{O} \mathrm{O} \mathrm{O}$}

COLLECTION DE PAPIERS SCIENTIFIQUES

\section{SUR LES MATÉRIAUX DE LA CONFÉRENCE SCIENTIFIQUE ET PRATIQUE INTERNATIONALE «PROBLÈMES ET PERSPECTIVES D'INTRODUCTION DE LA RECHERCHE SCIENTIFIQUE INNOVANTE» 20 novembre 2019 • Bruxelles, Belgique}

\section{VOLUME 5}

Ukrainien, russe, français, anglais et kazakh

Les matériaux sont imprimés dans le texte de l'auteur Le comité organisateur ne partage pas toujours la position des auteurs Pour l'exactitude de ce matériel, les auteurs portent la responsabilité

Signé pour impression le 29.11.2019. Format $60 \times 84 / 16$.

Papier offset. Arial type. Impression numérique

Feuilles imprimées conditionnées 7,32 .

Un tirage de 100 exemplaires.

Imprimé à partir de la mise en page originale finie.

Coordonnées du comité d'organisation:

21037, Ukraine, Vinnytsia, st. Zodchih, 18, bureau 81

Plateforme scientifique européenne

Téléphones: +38 098 1948380; +38098 1956755

E-mail: info@ukrlogos.in.ua

www.ukrlogos.in.ua | www.ojs.ukrlogos.in.ua 